\section{9 高脂血症の増加とその影響因子の検討}

国立病院九州医療センター内科、九州大学第二内科* 上野道雄、富永光裕、土橋卓也*、江藤仁香、 中村義人*、後藤健一*、佐内 透

【目的】最近の高脂血症の增加に及ほす環境因子を検討 する。

【方法】福岡国税局の成人男子 860 名（平均年齢 $30 \pm$ 6歳）を対象に、1984年から1997年までの長期追跡調査 と同局の成人男子全体 2200 名への断面調査を毎年行うた。 【結果】追跡調査での血清コレステロールと体重は、13 年間で $18 \pm 23 \mathrm{mg} / \mathrm{dl} 、 3.2 \pm 0.8 \mathrm{~kg}$ 各々上昇した。追跡開始 時の対象と抽出基準を一致させた1997年度職員と比較す ると、後者の血清コレステロールが9.8mg/dl高く、高脂 血症（血清コレステロール $240 \mathrm{mg} / \mathrm{dl}$ 以上）の頻度も $15.2 \%$ と開始時の $7.7 \%$ に比し大きかったが、血圧值、高 血圧症の頻度に差異はなかった。追跡調査では、血清コ レステロールと体重の増加が若年群ほど顕著であった。 この現象に一致して、血清コレステロールと年齢の正の 相関が10年目に消失し、逆に肥満度と年齢の負の相関が 4年目から出現し、各々継続した。断面調査でも同様の 結果であった。

【結論】経年的に体重が増加し、かつ年齢と肥満度に負 の相関を認めたことは、環境因子の悪化 (肥満) が若年 層に顕著に出現し、このことが最近の高脂血症の増加の 主要因子と考えられた。今後、肥满の中高齢者への波及 とともに、高脂血症のさらなる增加が危惧された。

150

ホモシステインによる Extracellular Superoxide dismutase(EC-SOD)の血中遊離增加作用

産業医科大学第二内科、岐阜薬科大学臨床薬凪学研究室 ${ }^{1}$ 長井 善孝、宮本 雅治、太崎 博美、中島 康秀、足立哲夫 ${ }^{1}$

【目的】血中ホモシステインの上昇は、動脈硬化への関与が強く 示唆されているが、その機序については不明である。一方、 EC-SODは血管内皮表面のヘパラン硫酸に結合し、内皮近傍で 生じた活性酸素を不均化反応により除去する。我々は、ホモシス テインが 1, NOの bioavailabilityを短縮する 2, 血管内皮表面 のヘパラン硫酸に結合しているアンチトロンビン IIIAT III)を血 中に遊離させるという2つの報告に注目し、ホモシステインが、 AT III と同样にEC-SODを血中に遊離させるため、NOの bioavailabilityが短縮され、動脈硬化が起こるという仮説をたて、 これを検証した。【方法】虚血性心疾患疑いにより冠動脈造影を 行った連続男性患者 100 人において、早朝空腹時に採血を行い、 ホモシステインはHPLC法により、EC-SODはELISA法により測 定した。冠動脈造影では75\%以上を有意狭窄とし、かつGensini scoreでスコア化した。【結果】ホモシステインとGensini score は正相関 $(r=0.279, \mathrm{p}<0.01)$ を示し、また有意狭猚群 $(\mathrm{n}=64)$ て $12.18 \pm 4.7$ と、对照群（ $n=36 ）$ の $9.48 \pm 3.0$ と比較し、有意に 上昇していた。また、ホモシステインは血中EC-SODレベルと も有意に正の相関 $(r=0.512, p<0.0001)$ を示した。【総括】以 前我々は血管内皮に結合しているEC-SOD の低下が冠動脈狭窄 と有意に相関することを示した。今回の結果からは、ホモシステ インの、動脈硬化を起こす機序の一つにEC-SODの内皮からの 遊離が関与していることが示唆された。

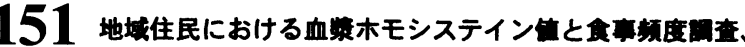

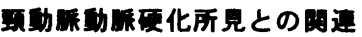

大阪府立成人病センター1) 高知県衙生研究所 ${ }^{2}$


内藤義彦 ${ }^{11}$ 、中川裕子 ${ }^{11}$ 、飯田 稳 ${ }^{1)}$

【目的】動脈硬化性疾患の危険因子として血槳ホモシステイン(以下 Hcy）が注目されているが、本邦における動脈硬化性疾患の危険因 子としての意義や食生活習慣との関連は明らかではない。本研究て は地域住民を対象として、Hcy値と食事頻度拥查、頭動脈超音波検 査所見の関連を検討することを試みた。

【方法】対象者は高知県 $N$ 町の 60 歳 74 歳の男性で䛻瑟器倹診を

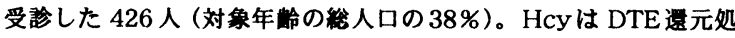
理・蛍光誘導体化による高速液体クロマトグラフィで測定した。頚 動脈超音波検查は、被䟻者の左右それぞれの総頊動脈、及び分岐部 から内箕動脈にかけてを描出して IMT-MAXを指標として動脈硬化 の進展度を判定した。同時に食事頻度調査により食生活のパターン を把握して Hcy 值との関連をみた。

【結果】 Hcy 值の平均値は $11.1 \pm 4.7 \mu \mathrm{m} / \mathrm{L}$ でり、分布箸囲は $1.9 \sim 49.8 \mu \mathrm{m} / \mathrm{L}$ でっっ。食事頗度調査と Hcy 値の関連を見 ると、魚、牛乳、野菜は摄取頌度が高いほど Hcy 值が低くなる倾 向を示した。Hcy值のQuartile別の頚動脈動腺硬化性变化の有所見 者の割合は、低い方から順に $9.4 \% 、 18.7 \% 、 8.4 \% 、 26.4 \%$ あっ た。ロジスティック回帰モデルを用いて、年数、脂質代謝異常、高 血圧、㜍尿病、契煙、アルブミン、クレアチニンを調整すると、第 4 Quartile の第 1 Quartile に対する動脈硬化性変化を有するオッ ズ比は 2.8(1.2-6.7)であった。

【結詓】西日本（四国）の非都市的地域の高踰者男性において、 1) Hcy 值は魚、牛乳、野菜の摄取制度と負の関連を示した。 2)他の危険因子を調整しても Hcy 值と頚動脈の動脈硬化性変化に は有意な正の関連を認めた。

152

喫煙および高ホモシステイン血症が血墏 nitrate/nit rite (NOx)濃度に及ぼす影響 防衛医科大学校第 1 内科 1 、同検査部 ${ }^{2}$ 、三越厚生事業団 ${ }^{3}$ 綾織誠人 1 、久田哲也 ${ }^{1}$ 、林 克次 ${ }^{2}$ 、鈴川満雄 ${ }^{1}$ 、吉田 博 ${ }^{1}$ 、 西脇正人 ${ }^{1}$ 、山下 毅 ${ }^{1}$ 、伊藤利光 ${ }^{1}$ 、中島 啓 ${ }^{1}$ 、東 賢治 ${ }^{1}$ 、 米村 篤 ${ }^{1}$ 、石川俊次 ${ }^{1}$ 、大鈴文孝 ${ }^{1}$ 、玉井誠一 2 、中村治雄 ${ }^{3}$

【目的】血漿 nitrate/nitrite (NOx)は nitric oxide (NO)の終産 物として、循環血中の NO 量を反映するとされる。血管内皮機能 を招来するとされる喫煙、高ホモシステイン血症および他の冠動 脈危険因子が血墏 NOx 濃度に及ぼす影響について検討した。

【方法】 236 名の成人健常男性から空腹時血を得て、NOx を Griess 法、ホモシステインを HPLC 法、血清脂質、血糖、フル クトサミンを定法で、喫煙のマーカーとして血墏チオシアン酸を Pettigrew の方法で測定した。さらに対象を喫煙群 $(n=121)$ 、非 喫煙群 $(n=115)$ に分けて検討した。

【結果】血漿 NOx 濃度と、一日喫煙本数、血漿チオシアン酸、 血漿ホモシステインの間にいずれも有意な負の相関を認めた。血 清脂質、血糖、フルクトサミン、血圧と NOx との相関は認めら れなかった。対象を喫煙者のみとして検討しても、血墏 NOx と チオシアン酸濃度との負の相関は有意であった。血墏 NOx は喫 煙群において、非喫煙群と比べ有意に低值を示した。

【結論】喫煙、高ホモシステイン血症による内皮機能障害は、こ れらによる動脈硬化惹起の機序の 1 つであると考えられている。 血洯 NOx 濃度を測定することにより、喫煙および高ホモシステ イン血症による循環血中 NO 量の減少が示唆された。今回の検討 で喫煙および高ホモシステイン血症により内皮機能障害が惹起 されることを支持する結果が得られた。 
153 冠動脈疾患における血墏ホモシステイン濃度についての検討

防衛医大第 1 内科、同臨床検査部 1)、三越厚生事業団診療所 ${ }^{2)}$ 、 東海大学大磯病院 ${ }^{3)}$

岩本紀之、久田哲也、鈴川満雄、綾織誠人、吉田 博、伊藤利光、 中島 啓、東 賢治、米村 篤、澤田正二郎、小倉正恒、富安幸 志、西脇正人、龁谷利雄、石川俊次、本間康彦 ${ }^{3}$ 、宮島恵美子 ${ }^{2}$ ) 山下 毅 ${ }^{2}$ 、林 克次 ${ }^{1}$ 、玉五井誠一 ${ }^{1}$ 、大鈴文孝、中村治雄 ${ }^{2}$

【目的】多くの疫学調査において血墏ホモシステイン濃度の増加が冠 動脈疾患 (CAD) の危険因子であると報告されている。今回、我々は $\mathrm{CAD}$ における血墏ホモシステイン濃度とそれに影響を与える諸因子 について検討した。【方法】平成 10 年 2 月から 10 月までの外来及 び入院の臨床診断あるいは冠動脈造影による CAD 患者 35 名と CAD のない対照 158 名について、空腹時採血、身長、体重、血圧測定を 行い、生活習慣調査を実施した。血清脂質は、醉素法、アポ蛋白は免 疫比濁法、血墏ホモシステイン濃度は HPLC 法および EIA 法にて測 定した。【結果】血漿ホモシステイン濃度は、CAD 群 $12.5 \pm 12.6$ $\mu \mathrm{mo} / 1$ 、対照群 $116 \pm 4.8 \mu \mathrm{mol} / 1$ で両群に有意な差を認めなかった。 全例においてホモシステインと諸因子について多重回帰分析を行っ たところ血墏アポ蛋白 A-I 濃度と有意な負の相関（ $\mathrm{r}=-0.24$, $\mathrm{p}=0.002)$ を、収縮期血圧と有意な正の相関（ $\mathrm{r}=0.20, \mathrm{p}=0.008)$ を認 めた。BMI、コーヒ一、喫煙との間には有意な相関は認められなかっ た。【結論】CAD 群とコントロール群との間に血墏ホモシステイン 濃度に有意な差を認めなかった。血槳ホモシステイン濃度と血漿アポ 蛋白 A-I および収縮期血圧の間に有意な相関関係を認めた。

\section{M T H F R 造伝子多型とホモシスティン、菜酸 ビタミン B ${ }_{12}$ 傅との间}

高知県衡生研究所 '”, 金沢大学第 2 内科 2)

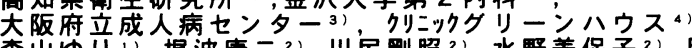

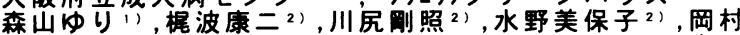

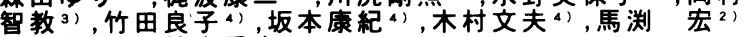
出口祐男 ', 鈴木秀吉

【目的】ホモシステインをメチオニンに再メチル化する 際に必要な基留である5-methyTHFは5,10-メチレン・テ トラ匕下萧酸通元酥素（MTHFR）により生成される。 血清中の葉酸は5-methyTHFの形䈍で存在することから， UTHFR进伝子多型別にホモシスティン, 菜酸(5-methyTH

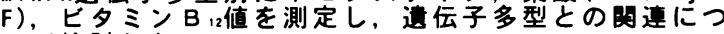
いて検討した。

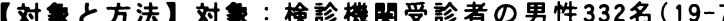
1 歳平均年秢 40.9土11.7), 女性659名(17-74藏平均年秢


システイシはHPLC、葉酸(5-methyTHF)とビ夕ミシB 1, 化学発光兔疫測定法, WTHFR遭伝子多型の同定はPCR-RFLP 法で行った。

【蛣果】MTHFR遗伝子多型の頻度 (AA/AV/VV) は，男性 では44/42/14(\%), 女性では41/46/13(\%)であった。遗伝 子多型別の男女の木モシステイン値は、AA型は9.4士2.8

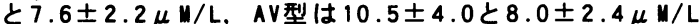

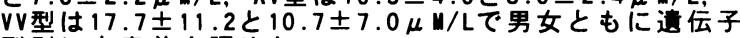
型別に有意差を認めた。

5-methyTHF値は男性のAA型とVV型 $(p<0.005)$ ，女性の AA型とVV型 $(p<0.005)$ ＡV型とVV型 $(p<0.05)$ で有意差 証めた 5-methyTHFとホモシステイン俌は女性のVV型を 除いて各䢖伝子多型の中で有意な負の相阔を示した ビタミシB12值は男女ともにMTHFR击伝子多型间での対 比較による有意差は認めなかった。

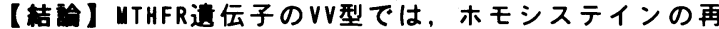
メチル化に必要な基質である5-methyTHFの低下により， ホモシスティシの高值を来している可能性が示嘫された。
155 ホモシステインと動脈石灰化

慶應義塾大学医学部老年科、1）国立循環器病センタ一代謝内科、 2）川崎井田病院内科、浦和市立病院 3)、済生会中央病院 4) 新井康通、広瀬信義、都島基夫1）、藤井効2）、村山晃3）、木村満4）

<目的> 高ホモシステイン血症は動脈硬化の危険因子とされ るが、その機序については不明の点が多い。我々は本学会におい て、ホモシステイン負荷家鬼を作成し動脈硬化に石灰化が起こる ことを報告した。今回ヒトにおいても動脈石灰化にホモシスティ ンが影響をおよぼすかを検討する。

〈対象と方法〉 本試験に同意した高コレステロール血症患者 を対象とした。12時間fastingの後採血を行い、一般生化学検査、 血中脂質、血糖、ホモシステインについて測定した。動脈硬化の 程度を調べるために、都島らの方法に基づいて、大動脈 $\mathrm{CT}$ 検査を 行い、分岐部での石灰化度を求めた。

<結果> 解析対象は 28 名で男性 7 名、女性 21 名、年齢の平均 は61.9 6.7歳であった。対象の総コレステロール平均値および標 準偏差值は $258 \pm 22 \mathrm{mg} / \mathrm{dl}$ 、トリグリセリド $169 \pm 119 \mathrm{mg} / \mathrm{dl} 、$ $\mathrm{HDL}$ - C $57 \pm 14 \mathrm{mg} / \mathrm{dl}$ FBS $98 \pm 10 \mathrm{mg} / \mathrm{dl}$ 、ホモシステイン $8.7 \mu \mathrm{m} / \mathrm{ml}$ 、収縮期血圧 $135 \pm 19 \mathrm{mmHg}$ であった。ホモシステイ ンの平均值以上を高ホモシステイン群 (高 $\mathrm{H}) 、$ 平均值未満を低ホ モシステイン群（低H）とし両群で各種パラメー夕、動脈石灰化度 を比較した。高 $\mathrm{H}$ と低 $\mathrm{H}$ では脂質、血糖、血圧、年齢、BMI は有 意差を認めなかった。しかしホモシステイン濃度 $(11 \pm 3$ vs 6.8 $\pm 1.2 \mu \mathrm{m} / \mathrm{ml} 、 \mathrm{p}=0.0001$ )、石灰化度（19 vs $10.5 \% 、 \mathrm{p}=0.0057$ ) で有意差を認めた。

〈考察〉 ホモシステインは動脈石灰化に影響をおよぼす可能 性が示唆された。さらに動脈石灰化がホモシステイン治療などの 介入により改善する可能性があることが考えられ今後の検討が期 待される。

\section{6}

$$
\begin{aligned}
& \text { 一般住民における血中ホモシステイン漕度と栄養提取量 } \\
& \text { について }
\end{aligned}
$$

日本女子大学家政学部 ${ }^{1}$, 国立循環器病センター内科 ${ }^{2}$, 慶応義熟 大学内科 ${ }^{3}$, 伊乵慶応病院栄養指導, 社会保険埼玉中央病院内科 ${ }^{5}$ 丸山千寿子、都島基夫 2 、中野里美 ${ }^{3}$ 、京谷晋吾 2 、仲森隆子“ 丸山太郎 ${ }^{5}$

[目的]血中ホモシステインが冠動脈硬化症の独立した危険因子と して注目され、血槳Methyl ene tetra-hydrofolate reductase (MTHFR)遺伝子のC667T変異がホモシステイン港度に影警すると いわれている。一方高ホモシステイン血症に対してビタミンB 6 投与の奻果が報告されているが、日常的な栄養摄取状態が血中木

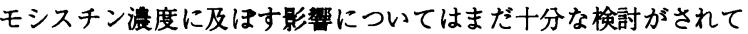
ない。そこで一般住民における血中ホモシスチン濃度と栄養摂取 量について調べた。

[方法]三重県度会郡紀勢町の農漁村の一般住民健康診断時に、血 漿ホモシスチン浪度およびMTHFR遗伝子多型を調べた。食事摄取 量および食習慣調查を留置法で行い栄養摂取量を算出した。 [結果]すべてのデータが得られた男性67名、女性143名中MTHFR 遗伝子多型の $\mathrm{AA} 、 \mathrm{AV} 、 \mathrm{VV}$ の出現頻度は、男性で40.2、46.3、 $13.4 \%$ 、女性で44.1、46.9、9.1\%であった。血墏ホモシスチン

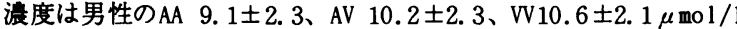

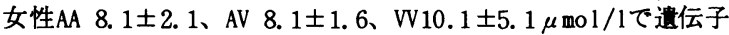
多型群間に有意な差は認められなかった。男性ではいずれの群に おいても血墏ホモシスチン浱度と一定の関保を示す栄養素は認め られなかった。女性ではAA群でV B 12摂取量が正、AV 群で鉄 摄取量およびVV群でV B 2摄取量が負の因子であった（p<0.05）。 [結論]本対象の農漁村住民の日常的摄取栄養素レベルでは、血中 ホモシスチン濃度に明らかな影幚を及ほさないものと思われた。 
157 小児の血清インスリン值と血清脂質 · 身体活動度 · 食事因子との関連について

兵庫県立成人病臨床研究所

松井育子、南部征喜、馬場茂明

（目的）小児において空腹時血清インスリン值が血清脂質・ 身体活動度 ・食事因子とどのような関連があるか検討する。

（方法）四国の北東部に位置するN 町で、1994年より年1回 小学校 $1 \cdot 4$ 年、中学校 1 年を対象に検診をおこない、体格測 定・血液検査・食事捸取頻度・身体活動度を調査した。

（結果）1.すべての学年で、総コレステロール值（TC） とHDL-コレステロール值（HDL-C）は正相関が、HDL-Cと トリグリセライド値（TG）は負相関が認められた。

2. 血清インスリン值（IRI）は年齢とともに上昇し、同年 齢では女子が男子より高值の傾向が認められた。すべての学 年でBMI（Body Mass Index）、上腕皮脂厚と正相関してい た。ウエストルヒップ比とは有意な相関を認めなかった。 3. 中学 1 年生をIRI值により高IRI群（IRI $11.4 \mu \mathrm{U} / \mathrm{mI}$ 以 上）、正IRI群（IRI $3.6 \mu \mathrm{U} / \mathrm{mI}$ 以上 $11.4 \mu \mathrm{U} / \mathrm{ml}$ 末満）、 低IRI群（IRI $3.6 \mu \mathrm{U} / \mathrm{ml}$ 未満）に分けて検討すると高IRI 群では身体活動度が低いあるいは脂肪エネルギー比が $30 \%$ 以 上の児童の頻度が高く、上腕皮脂厚の平均値も高かった。ま た高IRI群ではTCとHDL-Cの正相関が認められなかった。

（結論）小児においてはBMI・上腕皮脂厚がウエスト/ヒッ プ比より代謝指標としてょり有用と考えられた。中学 1 年生 では高脂肪食・身体活動度の低下による体脂肪の增加が、 IRI值の上昇させ、血清脂質値に影䈉をあたえている可能性 が示唆された。

\section{8}

小児成人病検診における相談室の有用性について

1日本大学医学部小児科学教室、柇並区医師会

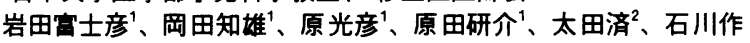
男、別府良男 ${ }^{2}$

【目的】小児成人病検診にてハイリスクと判定された学童のうち 希望者に相談室による個別指道を行った。指道の効果と有用性に ついて検討する。

【対象】対象は平成 5 年および 6 年に杉並区の小学校 44校およ び萧護学校 1 校に在籍した小学 4 年生の学童で、このうち小児成 人病検診に加し、管理基準に基ついて判定された管理指荅区分 が〈医学的管理が必要〉あるいは〈定期的経過钼察〉とされ、さ らに 3 年後の中学 1 年生時にも検診を受診した 261 人（男児 138 人、女児123人)である。

【方法】肥满度、動脈硬化指数の 3 年間の变化を、相談室受部群 と非受㟝群で比較した。平均值の比較はMann-Whitney U test を用いて行いp 0.05 を有意とした。

【結果】相談室受診者は男児35人(25.4\%)、女児23人(18.7\%)で あった。男児の肥渾度の变化は相談室受搒群で $-5.1 \pm 1.9$ $($ mean $\pm S E)$ 、非受讋群で $-0.2 \pm 1.1$ 、助腺硕化指数の变化は受 診群で $-0.7 \pm 0.1$ 、非受款群で $-0.3 \pm 0.1$ であった。ともに受診群 で有意に大きく低下していた。一方女児では、肥澫度の变化は相 談室受䛦群で $-6.8 \pm 2.1$ 、非受診群で $-3.8 \pm 0.8$ 、功腺硬化指数の 变化は受診群で $-0.9 \pm 0.2 、$ 非受診群で $-0.6 \pm 0.2$ であった。とも に受部群の方が大きく低下する倾向は認められたが、統計学的に 有意ではなかった。

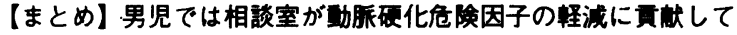
いると考えられた。女児においては有意な結果が得られず、相談 室受診制も低いことから今後の相談室の遇用の課题としたい。
159 神戸大学医学部第一内科, 保健学科* 田口真子, 谷口隆弘 堂本康治, 河崎悟, 高橋知三郎, 高橋明広, 石川雄一*, 横山光老

【目的】ob遺伝子の産物であるレプチンは体脂肪量とよく 相関すると言われている。脂肪量は動脈硬化病変の発生、進 展に関与していると推測されるため、我々は血清レプチン濃 度と冠動脈病変枝数との関連について検討した。【方法】対 象は1997年7月から1998年10月までに当院にて心蔵カテーテ ル検査を行った95名（男78名女17名）、平均年齢はそれぞれ $61 \pm 11$ 歳、63 09 歳。早朝空腹時に採血を行い、レプチン、 総コレステロール、トリグリセリド、HDL-C、血糖、インス リン、TNF- $\alpha$ を測定した。冠動脈病変枝数は、心臓カテー テル検査にて $75 \%$ 以上の狭窄を器質的病変として数えた。ま た、薬物負荷にて有意狭窄を生じた症例は冠攀縮性ありとし た。【結果】血清レプチン濃度はBMIと正相関を示した （r=0.40 $\mathrm{p}<0.0005 ） 。$ 血清レプチン濃度は女性で有意に高 い値を示した（p<0.001）。冠動脈病変の有無、病変枝数、 冠攀縮性の有無によって血清レプチン值に差はみられなかっ た。家族歴や心筋梗塞の既往の有無、冠動脈危険因子数につ いても検討したが、いずれにおいても血清レプチン濃度に差 は見られなかった。【結論】我々の結果では血清レプチン濃 度は冠動脈病変に密接には関連していなかった。

\section{0 動脈硬化における Serum Amyloid P Component の役割} に関する研究

李样安、畑中櫓、由谷親夫、斯波真理子、下門顕太郎 国立循環器病センター研究所

目的：SAP は肝臟で合成される pentraxin familyに属する血清 蛋白である，多くの蛋白と結合すること、急性炎症で増加し、 そのノックアウトマウスはアルツハイマー小体ができにくいな どの事実から生体機能維持に重要であると予想されるが、その 機能は不明のままである。本研究ではヒト動脈硬化巣での SAP の有無およびその存在形式を検討した，方法 : ヒト剖検例より 得た大動脈（10 名）を、抗 SAP 抗体による免疫組織化学により SAP の存在を検討した。Ca または EDTA を含むバッファー、次い でコラグナーゼ処理により SAPを抽出し、electroimmunoassay により定量、Western blot, gel filtration, ligand blotting により検討した。また solid phase ELISAによりリボ蛋白との 結合を検討した。結果：1）SAP は動脈硬化内膜に多く存在し、 若年者の正常動脈には検出されなかった。その含量は動脈硬化 の程度（コレステロール含量）と相関（P<0.05）した，とりわ け内膜可溶性 SAP 含量、およびコラゲナーゼ処理後に抽出され る中膜中の含量と動脈硬化の程度は良く相関した，2）Ligand blotting により動脈硬化巣の可溶性分画に 43Kd $の$ SAP 結合蛋 白の存在がしめされた。3)リポ蛋白のうち、HDL と VLDL と SAP は特異的に結合したが、LDL とは結合しなかった：考察：SAPが 動脈硬化の進展にしたがって動脈内に增加することから、動脈 硬化の進展に SAP が関与する可能性が考えられる。SAP は血管 壁の分子に結合して正常の機能を阻害するかもしれないし、他 の急性反忘蛋白が炎症で果すような役割を慢性炎症反応として の動脈硬化の進展において果すかもしれない 
161

清C-Reactive Protein(CRP)基礎值とPTCA後再狭窄との 関連

兵庫医科大学第 1 内科森本真史、藤岡由夫、奥村隆啓、正井 美帆、藤原正義、三好彩、桝谷元丸、立石順、岩崎忠昭 自衛隊阪神病院内科細合浩司

【目的】急性期反応性蛋白であるC-Reactive Protein(CRP)は、動脈 壁でも認められ、動脈硬化の進展過程に関連すると考えられてい る。CRPと冠動脈疾患(CHD) との関連は以前から検討され、CRP 基礎值がCHDの危険因子になり得るとの報告も少なくない。我々 は血清CRP基礎値と待機的経皮的冠動脈形成術(PTCA)後再狭窄の 有無との間に関連があるか検討した。【方法】待機的PTCAを施行 したCHD患者で、約 6 カ月後再評価で再狭窄を認めた 58 例（R群）、 再狭窄を認めなかった58例（NR群）、CHDのないコントロール 64例（C 群）を対象とした。血清CRP基䃈值は入院時のものを使 用し、肝 - 堅疾患、他の炎症性疾患、悪性疾患等の症例は除外し た。尚R群とNR 群では性別、喫煙の有無に有意な差は無かった。 【結果】年齢、BMI、高血圧症の頻度や投薬内容、血清総コレス テロール、HbAlcは3 群間で有意な差は無かった。CHD患者（R群、 NR 群）はC 群に比べて血清中性脂肪、LP(a)が有意に高値で、HDL が有意に低値であったが、R群とNR 群の間ではこれらの值に有意 な差は無かった。血清 CRP基碮值を $0.3 \mathrm{mg} / \mathrm{d}$ 以上と $0.3 \mathrm{mg} / \mathrm{d}$ 未满と に分けて3群間で比較検討したが、再狭窄に対する危険性に関して 有意な結果は得られなかった。【結論】今回の検討では血清 CRP 基磫値と経皮的冠動脈形成術後の再狭窄の有無との間に有意な関 連は認められなかった。
162

ジヒドロピリジン系Caブロッカー塩酸ベニジピンのLDL被 酸化性に及ぼす影響の検討

防行医科大学校第 1 内科、三越黾生事業団*

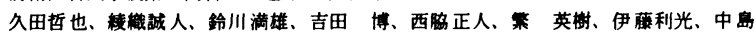

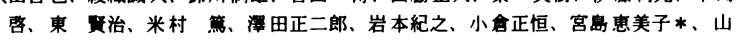
下 媇*、石川俊次、大输文毒、中村治䬺 $*$

【目的】多くのジヒドロピリジン系CaフフロッカーはLDLの被酸化性を抑制 する作用を有することが報告されてきた。今回我々はジヒドロピリジン系 Caフロッカー塩酸ベニジピンのLDLのin vitro酸化及びJ774マクロファー 汁培美細胞を介する酸化に及ほす影害について検討した。【方法】正常健 常男性の空腹時採血により得た血㙁酸ベニジピンおよびニフェジピン を加え（最終湍度それぞれ $0.01,0.02 \mu \mathrm{mol} / 1,0.15,0.30 \mu \mathrm{mol} / \mathrm{l}$ ）、37亿て 6 時間インキュベートし、超遠心法でLDLを分離し、V70によるLDL酸化 時のlag time (LT)およびpropagation rate (PR)をEsterbauerらの方法に 淮じて求めた。またJ774マクロファージ細胞をDMEMメティウムで培荃し、 Ham-F10メティウムに交換し、各䈨度になるように㙁碜ベニジピンおよび ニフェジヒンを加え、LDLを8時間インキュベーションし、メティウム中 のTBARSを測定した。【結果】㙁酸ベニジビン及びニフェジピンにより LTは延長、PRは诚少の㥧向を示した。J774細胞を介した酸化において表 のようにメティウム中TBARS值が有意に低下した。

\begin{tabular}{|c|c|c|}
\hline & $(\mu \mathrm{mol} / 1)$ & TB.IRS (nmol/L.DL.mg protein) \\
\hline コントロール & & $60.9 \pm 6.9$ \\
\hline \multirow[t]{2}{*}{ 脈ベニジビン } & 0.00 .1 & $41.4 \pm 6.9 \pi$ \\
\hline & 0.01 & $35.4 \pm 8.4 *$ \\
\hline & 0.02 & $33.7 \pm 2.9 *$ \\
\hline \multirow[t]{4}{*}{ ニフェジヒン } & 0.12 & $41.0 \pm 2.7 *$ \\
\hline & 0.15 & $33.3 \pm 4.3 *$ \\
\hline & 0.30 & $35.8 \pm 2.1 *$ \\
\hline & $(\pi: P<$ & $05 . *: P<0.01 \vee \mathrm{s}$ コントロール) \\
\hline
\end{tabular}

【結論】ジヒドロピリジン系Caプロッカー塩酸ベニジピンにはニフェジピ ンとほほ同等のLDLの被酸化性の㧕制効果があると考えられた。 の增加を抑制することが示唆された。
163 酸化 PC 代謝䣼素としての LCAT の性筫

○板部洋之 1 、細谷竜太 1 、高野達哉 1 、自見至郎 2

（1 帝京大・薬・病態生化学、2 福岡大・医・二病理）

ホスファチジルコリン（PC）の酸化生成物を認識する DLH3 抗体 を用いて測定したヒト血等中の酸化 LDL レベルは、家族性 LCAT 欠 損症患者で健常者の 3 倍以上高かった。酸化処理した放射標識 PC を健常血墏と共に保温するとコレステリルエステル（CE）に加え 種々の代謝産物が生じ、LCAT 阻害肪存在下あるいはLCAT 欠損症 患者血墏ではCEと他の代謝産物のいずれも生じないことなどから、 LCAT に酸化 PC 代謝活性の存在を見出した（昨年本学会で報告）。 酸化 PC (9-CHO PC、PCOOH) をLDL に微量添加すると、添加し た量に依存して DLH3 抗体との反応性が増加する。酸化 PC 添加LDL を HDL と共に保温した際、酸化 PC 添加 LDL の DLH3 抗体結合性は 著しく減少したが、LCAT 阻害凨存在下では変化しなかった。この 結果から、LCAT がリポ蛋白粒子中の酸化 PC を代謝しうることが示 唆された。PCの 2 位の脂肪酸が短鎖アルデヒドに酸化された 9-CHO PC、5-CHO PC の放射標識体を調製し、血墏および HDL 画分と共に 保温すると、LCAT 依存的に放射性代謝産物が生成した。次に、放 射標識遊離コレステロールを添加した血㢡に、非標識の種々酸化 PC を加えて保温したところ、 $\mathrm{PCOOH}$ や $\mathrm{PCOH}$ からは代謝産物が生じ たが、9-CHO PC、5-CHO PCからは代謝産物が生じなかった。さら に、放射標識ジグリセリドを添加した血獎に非標識の種々酸化 PC を加えてみたが、同様の結果であった。LCAT は、種々の酸化 PC 反 応産物に対し代謝活性を有するが、酸化された長鎖脂肪酸をコレス テロールに転移し、一方短鎖アルデヒドに対してはそれと異なる代 謝を行い、LDL 上の酸化 PC 蓄積を抑制しているものと考えられた。

\section{4 血中霞化 LDL と Lp 分画像にみる変性 LDL との関連}

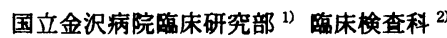 小西奎子 ${ }^{122}$ 松原弘和 ${ }^{21}$ 佐々木久雄 ${ }^{11}$}

変性 LDL の動脈硬化への関与は大きく、特に酸化 LDL は重要な factor と考えられている。弥腫ホモジネートを抗原とするモノクロー ナル抗体を用いた系で酸化 LDL を测定し、電気泳動像で観察される リポ蛋白(Lp)の贫的異常との関連について検討する。【方法と対象】 酸化 LDL はフォスファチジルコリンの酸化生成物を認墥する抗体 $\mathrm{DLH}_{3}$ とアポ $\mathrm{B}$ 抗体を用いた ELISA で测定。Lp 分画は PAG 電気泳 動(リポフォー)で测定。同時に TC、TG、HDL-C、LDL-C、Lp(a)、 ApoA-1、ApoB、ApoE を测定した。煡診者 581、结尿病 185、動脈硬 化性疾患 137 例を対象とした。酸化 LDL の基準値は ROC 曲線から

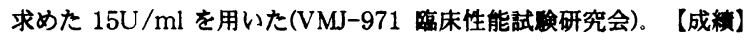

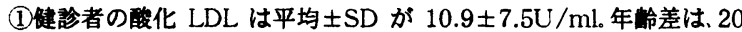
歳代 $9.4 \pm 6.9 .30$ 歳 $9.6 \pm 6.1 、 40$ 歳 $11.0 \pm 7.0 .50$ 歳 $13.2 \pm 8.6 \mathrm{U} / \mathrm{ml}$ で、 40 と 50 歲間に有意差有り.(2) 50 歳代男 84 名 13.9 48.7 と女 69 名 $12.3 \pm 8.6 \mathrm{U} / \mathrm{ml}$ の間には有意差なし。(3)Lp(a)と $\mathrm{r}=0.534$ の相関 性有り.LDL-C と ApoB には $\mathrm{r}=0.168$ など. 他の脂筫とは相関性な し. (4) Lp(a) $20 \mathrm{mg} / \mathrm{dl}$ 以上群は若年でも有意に高値。 50 歳て $18.8 \pm$ $10.9 \mathrm{U} / \mathrm{ml} \cdot$ 陽性率 $49.1 \%$ vs $10.5 \pm 5.0 \cdot 16.3 .20$ 嵅で $13.0 \pm 9.2$. 43.8 vs $7.9 \pm 5.2 \cdot 5.0$. (5)Lp 分画像 $\mathrm{S}$ 型 $\angle \mathrm{A}<\mathrm{N}<\mathrm{D}$ の関係にあり. $\mathrm{A}$ と $\mathrm{N}$ 型の間に有意差有り $(11.6 \pm 7.4 \mathrm{U} / \mathrm{ml} \cdot 23.4 \%$ と $14.6 \pm 9.8 \cdot 33.9)$ 。 small LDL 有無には有意差なし。fast $\beta$-Lp 有無では有意差有り $(+: 14.3 \pm 11.6 \mathrm{U} / \mathrm{ml} \cdot 32.6 \%$ vs $-: 11.4 \pm 6.9 \cdot 20.3)$. DM p動脈硬 化群でより大きな有意差を認めた。650 歳代の䋖診者に対し、娌脈硬 化群は有意に高值高陽珄率であるが DM には有意差なし。【結論】 Lp 分画像で観察される加铃に伴い出現・增加する変性 LDL の factor の 1 つは、同法で測定される酸化 LDL であった。 
165 15ーリポキシゲナーゼによる血槳リポタンパクの酸化

東京大学先端科学技術研究センター・ Humboldt University* 野口範子 - 山下裕雅 · 中村明朗 ·二木鋭雄 · Hartmut Kühn*

[目的]リポキシゲナーゼ(LOX)は生体内でLDLの酸化を惹き起 こす酸化酵素として注目されている。酵素的な酸化はラジカ ル的酸化とはその生成物が異なる。本研究はLOXによるLDL および血槳の酸化の特徴を明らかにすることを目的とした。 [方法]健常人の血槳から分離精製したLDL $0.8 \mathrm{mg}$ protein / ml PBS および血槳そのものに、ウサギ網状赤血球から精製し

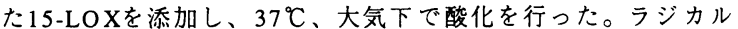
的酸化にはラジカル開始剤 $\mathrm{MeO}-\mathrm{AMVN}$ 用いた。脂質を抽出 し、UV検出器付HPLCにて、ホスファチジルコリンヒドロペ ルオキシド $(\mathrm{PCOOH})$ とコレステリルエステルヒドロペルオキ シド $(\mathrm{CEOOH})$ を定量分析した。PCOOHとCEOOHを分取し、 アルコールに還元後、トランスメチル化してリノール酸メチ ルを得た。HPLCでこのリノール酸メチルの 4 つの幾何異性体 を分離し、さらに、光学異性体 $(\mathrm{S}$ 体・ $\mathrm{R}$ 体)の分離分析を行っ た。[結果]LDLをラジカル的に酸化すると、PCOOHと CEOOH が生成し、生成量はCEOOHが多い。4つの異性体はほほ等し い割合で、またS 体とR体は1：1であった。これに対して、 15-LOXによる酸化では、やはりP COOHとCEOOHが ( $\mathrm{PCOOH<CEOOH)}$ 生成するが、13-シス,トランス型が選択的 で、また、 $\mathrm{S}$ 体が優先的であった。血槳には種々の抗酸化物質 が存在するにもかかわらず、15-LOXにより酸化は惹起された が、LDLと異なり、PC OOHの生成が $\mathrm{CEOOH}$ 上回った。異 性体分布はL D L と同様、S体が優先的であった。[結論]15LOXによりLDLおよび血漿りポタンパクは酸化され、䤃素的 酸化特有の立体、位置、光学特異的な生成物を与え、ラジカ ル的酸化とは異なることが明らかにされた。

166 血管平滑䯇細胞に対する楉化LDLの細胞增殖・遊走について の検討

1) 日本大学医学部病理学教室、2) 同第二内科学教室

3) 東京女子医科大学第一病理学教室

生沼利倫 ")、田口誠治 ${ }^{1}$ 、山田勉 ${ }^{1}$ 、櫻井勇 ${ }^{1}$

斉藤英治 ${ }^{2}$ 、藤岡考之 ${ }^{2)}$ 、小林楥雄 ${ }^{3}$

【目的】糖化LDL (GLDL)は、糖尿病における動脈硬化促進の一 要因とされている。今回、我々はGLDLと糖酸化LDL (GOxLDL)の 平滑筋細胞 (SMC) に対する細胞增殖能、細胞遊走能、growth factor受容体発現、apoptosis, matrix metalloprotease-3 (MMP-3: stromelysin) 活性を比較検討したので報告する。【方 法】 LDLを $200 \mathrm{mM}$ glucoseと $37^{\circ} \mathrm{C} て ゙ 4$ 週間反応させた GLDL、LDL にglucose と $4 \mu \mathrm{M} \mathrm{CuSO} 4$ を加え反応させたGOxLDLやLDLに glucose と抗酸化物 (buthylhydroxytoluene) を添加した糖化非 酸化LDL (GLDL-NOx) を用いて検討した。ヒト大動脈中膜由来 SMCを上記 3 種類のLDLと $37^{\circ} C 、 24$ 時間培垗ししSMC数を算定した。 同時にboyden chamber法でSMC遊走能を検討した。apoptosis (TUNEL法)、Bax蛋白、bcl-2蛋白及びmouse anti-human monoclonal platelet-derived growth factor receptor $\beta$ subunit (PDGFR) antibody陽性細胞を算定した。遊走したSMC をFITC標識casein含むgel上にのせ、MMP-3活性の程度を喾光 部の欠損の面積で表した。【結果】GLDL-NOxはSMC数を増加さ せ、GOxLDLはSMC数を減少させた。GLDL-NOx とGLDLはSMC遊走 能を亢進させた。特にGLDL添加により apoptosis、Bax、bcl-2 の発現が立進した。SMCにおけるPDGFR発現頻度はGLDL-NOx添 加で增加した。FITC標識casein欠損面積でみたMMP-3活性は GLDL-NOx とGLDL添加により六進する傾向にあった。精化LDLは 酸化の関与がなくとも上記の反応を促進しうると考えられた。 【結論】糖化LDLはSMCを增殖・遊走させ、また成長因子受容 体発現、apoptosis誘導、MMP-3の産生に関与することにより 動脈硬化性病変を促進させることが示された。
167 東北食効科学研究所、村上病院

中山信司、金澤武道、田中真実、工藤重光、打田悌治

[目的] 1)LDL (密度 1.006 1.063g/ml) は健常者 12 名と 虚血性心疾患（18名）の血漿から超遠心法により分離した。 2)糖質構造の分析は陰イオン交換カラム（宝酒造社製 PAL PAKType A）を用い、HPLCにより行った。0.7M木ウ酸緩衙 液(pH9.0)により溶出した。3)LDLを3Nトリフルオロ酢酸と 共に $100^{\circ} \mathrm{C} 、 3$ 時間加温し、それを2-アミノピリジンにて型 の如く糖の還元末端を蛍光標識(PA 化)し、HPLCにて分析し た。過酸化LDLについても検討した。

[結果] 1)LDL からは galactose、mannose、fucose 及び glucose と末同定の数個のピークが認められた。正常 LDL と 過酸化 LDL との間では差は認なかった。2)glucose／ galactose 比、 mannose /glucose 比は健常者に比して虚血 性心疾患患者で大であったが、mannose／galactose 比には 差はなかった。

[結語］虚血性心疾患患者と健常者とでは LDL の糖質構造に 差異があり、その差異にはLDLの過酸化は無関係である。

168 低比重リポ蛋白（LDL）の糖鎖立体構造と酸化 との関係について

新潟大学・医 - 検查診断学 岡田正彦、三井田孝、稻野浩一 柏崎中央病院・内科星山真理

【目的】動脈硬化症の発生には低比重りポ蛋白(LDL)の酸化が 重要であることが広く知られている。しかし、LDLのどのよ うな構造変化が問題となるのかはまだ良く分かっていない。 本研究では、LDL 糖鎖の立体構造と酸化との関係を調べた。 【方法】健常者の血墏より超遠心法でLDLを分離した。これ に 3 種類のエクソグリコシダーゼをそれぞれ作用させ蛋白よ り糖鎖を切断した。次に、各種エンドグリコシダーゼを作用 させ、単糖を順次切断した。これらオリゴ糖を蛍光標識しオ リゴサッカライドプレキャストゲル(BioRad 社)で電気泳動を 行ない一次構造を決定した。一方、同法で LDL 糖鎖の最外部 の単糖を切断したものとコア構造から切断したものをそれぞ れ作成し、常法に従い銅イオンを加えて酸化の lag time を計 測した。【結果】 LDL の糖鎖はすべて N-結合型で、3 種類の complex type と 5 種類の high mannose type が検出された。 また、最外部の単糖を切断しても lag time に変化はなかった が、糖鎖全体を切断すると延長が認められた。【結論および 考察】 LDL の糖鎖構造と酸化の lag time には関係のあること が分かった。糖鎖が酸化反応に対して防御的に働いている可 能性も示唆されるが、その構造変化と動脈硬化症発生との直 接的な関わりについてはさらに検討が必要と思われた。 
169

高リポ蛋白(a)血症に及ぼすアスピリンの影響 : アポリポ 蛋白(a)アイソフォームとの関連

徳島大学医学部第一内科, 国立療養所徳島病院内科 1 , 徳島県立 中央病院循環器科 ${ }^{2}$, 健康保険鳴門病院循環器科 ${ }^{3}$, 川島循環器 クリニック 4

赤池雅史，東 博之，高森信行，松本和也 ${ }^{1}$, 林 郁郎 ${ }^{2}$, 田村克也 ${ }^{3}$, 西内 健 ${ }^{4}$, 粟飯原賢一, 金川泰彦, 井内貴彦, 吉田智則, 香川礼香, 松本俊夫

【目的】我々は高リポ蛋白(a)〔Lp(a)〕血症においてアスピリン が血中 Lp(a)濃度を低下させることを見い出し, アポリポ蛋白(a) [apo(a)］の転写活性の抑制がその機序であることを報告してき た. そこで本研究ではアスピリンによる血中 $\mathrm{Lp}(\mathrm{a})$ 濃度の低下効 果と apo(a)の mRNA 量の規定因子の一つである apo(a)アイソフ オームとの関連について検討した.【方法】対象は冠動脈疾患あ るいは脳血管障害を有し, 血中 $\mathrm{Lp}(\mathrm{a})$ 濃度が $30 \mathrm{mg} / \mathrm{dl}$ 以上の 32 例 (男 20 例, 女 12 例, $64.3 \pm 11.3$ 歳) である. アスピリン $81 \mathrm{mg} /$ 日を連日投与し, 血中 $\operatorname{Lp}(\mathrm{a})$ 濃度は免疫比濁法により測定し， apo(a)アイソフォームは Utermann らの報告に基づき，F，B， $\mathrm{S} 1 \sim 4$ に分類した.【結果】血中 $\mathrm{Lp}(\mathrm{a})$ 濃度は投与 1 か月後に前 值の約 $80 \%$ に低下し，この効果は投与 6 か月後においても持続 していた. 分子量の小さい F などの apo(a)アイソフォームを有 する例や double band type の例では血中 $\operatorname{Lp}(\mathrm{a})$ 濃度が高值で, アスピリン投与後の血中濃度の低下も著明である例が認められた.

【結論】分子量の小さい apo(a)アイソフォームはクリングル構 造の繰り返し数が少ないことから転写効率が高く, mRNA 量が 多いと考えられ，この転写効率の相違がアスピリンによる apo(a) の転写抑制効果に関与している可能性がある.

\section{0 血清リボタンパク(a)值亡心筋梗塞慢性期貫任冠動脈造影所 見の関係について}

\section{順天堂浦安病院内科}

松田 、山崎 明、有馬 瑞浩、岡崎 真也、加納 達二

[目的]急性期に血栓溶解療法等の再潅流療法が施行できなかった 心能梗塞症例において、血清りポプロテインa值(LP( $(a)$ 值)が慢性 期責任冠動脈の残存狭窄度に及ほす影籍を検討した。

[方法]1993から1996年に冠動脈造影を行った症例のうち、急性期 に、血栓溶解療法、経皮的冠動脈形成術、ACバイパス術を施行で きなかった心胼梗塞症例で、慢性期に冠勳脈造影を行い、梗塞畐 任冠動脈が推定できた83例(平均年令58.2才,男性68例)を対象と た。 L p (a) 值が30 mg/dl以上の群(高值群) 25 例、30 mg/dl未満の群 (低値群)58例に分け、贯任冠動脈の慢性期冠動脈造影狭窄度、 TIMI flow grade、冠動脈病変枝数、body mass index(BMI)、血糖 值、血清総コレステロール値、HDL コレステロール値、中性脂肪 值、について後ろ向きに比較検討した。 [結果]全症例を対象とした比較では、Lp(a)高値群と低值群の間 て、、冠動脈病変枝数、BMI，血清脂货，血糖值に差を認めなかった。

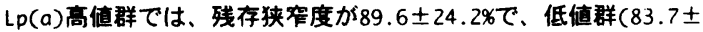
26.9\%)に比べ高い傾向にあったが有意差を認めなかった。対象を 搪尿病病歴の無い症例に限って比较すると、Lp(a)高値群で残存狭 窄度か有意に高かった。( $92.9 \pm 19.9 \%$ vs $80.4 \pm 29.4 \%, p=0.01)$ TIMI flow grade $0 \sim 1$ 症例が占める割合は、高値群で50\%に対し 低値群では27\%であった。

[結論]血清Lp $(a)$ レベルが高い非䛯尿病症例は、心媨梗塞慢性期に 专任冠動脈に、より高度の狭窄が残存し、その病態を修飾する可 能性が示唆された。
171 血中Lipoprotein(a)值の意義一老年者の予後調查より 東京医大老年病科 杉山 壮、岩本俊彦、小泉純子、清水武志、田中由利子、 高崎 優

【目的】Lp(a)]は動脈硬化の独立した危険因子とされるが、予後 との関係は一定していない。そこで老年期におけるLp(a)の意義 を知る目的で、老年者を対象として血中Lp(a)高值群と低值群の 予後を 5 年間にわたって追跡調查した。【方法】対象は1993年に 当科を受診した老年者で、血中Lp(a)值より 2 群、すなわち $\mathrm{Lp}(\mathrm{a}) 35 \mathrm{mg} / \mathrm{d}$ 以上の高值群( $\mathrm{n}=49) 、 20 \mathrm{mg} / \mathrm{d}$ 末满の低值群 $(\mathrm{n}=100)$ に 分類した。これら全例に一般検查の他、頭部CT検查、顒動脈超 音波断屏検查(US)、足関節血圧比測定を行つた。予後は追跡可能 であった高值群の48例、低值群の97例について、その生死、死亡 年月、死因、血管合併症 (脳卒中、心筋梗塞、ASOの進行)より生 存分析を行った。【結果】1) 背景 : 高值群、低値群の平均年龄 (各々78歳、77歳)、男女比に差はなかった。危険因子では高血圧 (40vs54\%) ・糖尿病 (10vs17\%) - 高脂血症(33vs29\%) ・喫煙(19vs $26 \%)$ 頻度に差はみられず、脳卒中の既往も同頻度 (33\%)であ った。2) 各群の検查所見 : 異常CT(73vs54\%)、異常US(83vs50 \%)は高値群で有意に多かった。API低値(35vs22\%)は高値群で多 い傾向を示した。3) 予後 : 死亡(年間死亡率)は18vs21例(9.4vs4.8 \%)あり、カプラン-マイヤー生存曲線によるlog-rank検定でも統計 量4.70 ( $=0.0301)$ と高値群の生存率は有意に低かった。重回帰 分析の結果、生命予後に与える因子の程度は年齢、脳病変の有無、 心電図所見、Lp(a)值で影響されたが、死因の半数は脳卒中を基 盤とした誤噍性肺炎であった。血管合併症（年間䍜病率)も10vs8 例 (5.5vs 1.8\%)と高値群で有意に高かった。【結語】 Lp(a)高值の 老年者では既に血管病変が各脿器で進展しており、5 年間の生命 予後は不良であることが示された。

\section{2}

Binswanger 脳症における Lipoprotein(a)の意義

名古屋第一赤十字病院神経内科

岡田洋平、浜田健介、渡辺正樹、真野和夫、渡㭡英夫

目的: ラクナ梗塞( $\mathrm{L}$ 群)、アテローム血栓性脳梗塞( $\mathrm{T}$ 群)、Binswanger 脳症(B 群)における Lipoprotein(a)（Lp(a)）の意義を検討した。 方法： 60 歳以上の 379 例（男性 214 例、女性 165 例 ; L 群 104 例、 T群 49 例、B群 77 例) において、全例の $\mathrm{Lp}(\mathrm{a})$ を測定し $40 \mathrm{mg} / \mathrm{dl}$ 以上の高値群、 $20 \mathrm{mg} / \mathrm{dl}$ 未満の低値群、その間の中間群に分類した。 また大血管病変の有無について、頚動脈超音波を用い左右頝動脈のプ ラーク最大高 $(\mathrm{mm})$ の総和(プラークスコア; PS)を求め、 $10 \mathrm{~mm}$ 以上 の高度群、 $3 \mathrm{~mm}$ 未満の軽度群、その間の中間群に分類した。B群 では、重症度の指標として長谷川式简易痴呆スケール(HDS-R)、かな ひろいテストを行った。また頭部 MRI T $\mathrm{T}_{2}$ 強調画像において、側脳室 前角における脳室周囲白質高信号域 $(\mathrm{PVH})$ の厚み $(\mathrm{mm})$ を測定した。 結果：1)全例において検討すると、Lp(a)は男女差を認めず、PS と正 に相関する傾向がみられた。2)B 群の Lp(a)は L 群より有意に高かっ たが、PS は B 群、L 群で有意差を認めなかった。3)B 群では PS 高 度群の Lp(a)は中間群、軽度群に比べて高い傾向を示した。4)PS が 軽度な B 群と L 群を比較しても、やはり $\mathrm{Lp}(\mathrm{a})$ は B 群において有意 に高かった。4)B 群の Lp(a)高值群では低值群、中間群に比べ HDS$R$ 、かなひろいテストの得点が有意に低く、Lp(a)と HDS-R は負の相 関関係を示した。PVH は Lp(a)の値により差は見られなかった。 結論 : Lp(a)は頭顐部大血管病変の高度なものにおいて高いと言われ ているが、今回の結果はそれに矛盾しないものであった。一方 Binswanger 脳症では頚動脈病変が軽度であっても Lp(a)は高值を示 し、重症例ほど高值を示す傾向があったことから、Lp(a)が Binswanger 脳症の病態に何らかの関連を持っていると考えられた。 
173 わが国における家族性複合型高脂血症の頻度

千菜大学第二内科 ${ }^{\prime}$ 、安房医師会病院 ${ }^{2}$ 、済生会船橋病院 ${ }^{3}$ 田永幸正'、武城英明 '、平 晃一'、森崎信要'、青木 謹 ${ }^{2}$ 、 原 久弥 ${ }^{2}$ 、梅图 忠 ${ }^{2}$ 、籍宮正樹 ${ }^{3}$ 、齋藤 康

【目的】家族性複合型高脂血症FCHLは、虚血性心疾患を高頻 度に合併する逢伝性疾患である。その病態は、高コレステロール 血症に加え、高トリグリセライド血症を合併することが特徽とさ れる。しかしながら、本疾患の診断には詳細な家族歴の聴取が必 要なことから、わか国における正確な発症頻度は不明である。我 々は、これまでに千集紧安房地区住民におけるFCHL患者を家系調 查により同定し、その病態として高アポB血症が存在すること、さ らに頚勤脈超音波法による内膜中膜複合体肥厚の進展を明らかに した。今回、FCHL発症頻度について検討したので報告する。

【対象と方法】対象は、1994年より3 年间の住民検款を受診し た安房地区住民である。採血は早朝空腹時に行い、過去3年間の検 診で 2回以上、TC220およびTG200mg/dI以上の高脂血症者 (HbA1c 7.0以下、TG1000mg/dI以下)を抽出し、外来受診した住 民について閣診、家系調査を行った。FCHL家系は、厚生省特定疾 恶原発性高脂血症調查研究班による診断基準により同定した。

【結果】 3 年間の住民検刢受喆者は24081人だった。このなかで 上記の抽出基準を満たす対象は377人(1.57\%)存在した。このうち 地理的条件より 212 人を抽出し、高脂血症外来受喆を文書で通知し た。実際に外来受診した111人について、問診、家系調査および血 海脂筫検查を施行し、钐断基準をみたすFCHL38家系を同定した。 これらの抽出基準によるFCHL頻度は、全対象の0.54\%だった。

【結諭】わが国におけるFCHLの最低頻度は $0.54 \%$ と推測され、 家族性高コレステロール血症より高頻度で存在することが明らか になった（本研究は厚生省特定疾患研究原発性高脂血症調查研究

（班長 北徽）の一部であり、名古屋大学公衆衛生学、曾息英 明、近藤高明両先生の協力により行われた）。

174 Effect of naturally occuring apoA-I mutation on binding of apoA-I to lipoproteins and cells

Wei Huang, Akira Matsunaga, Takafumi Koga, Mari Kug, Wei Li, Tomoko Shinkawa, Jun Sasaki, Kikuo Arakawa

Department of Internal Medicine, School of Medicine, Fukuoka University

Aim: ApoA-I, major protein moeity of HDL, play an important role in HDL metabolism. To investigate the effect of the point mutation on binding of apoA-I to lipoproteins particles and cells, two naturally occuring apoA-I mutants identified in our laboratory, apoA-I

$($ Lys $107 \rightarrow 0$ ) and apoA-I Nichinan (Glu235 $\rightarrow 0$ ) were expressed in E. coli /pGEX vector expression system.

Methods: Mutant versions of the proapoA-I cDNA were prepared by in vitro mutagenesis using the Kunkel method. The proapoA-I were produced from a bacterial expression system as GST gene fusion proteins and purified by glutathione column, anti-apoA-I affinity and Sephacryl S 300 column. Recombinant proapoA-I (r-proapoA-I) were labelled with sodium $\left[{ }^{125} \mathrm{I}\right]$ iodide. The association of ${ }^{125} \mathrm{I}$ I-r-proapoA-I with human lipoproteins fractions $(\mathrm{d}<1.225)$ was analyzed by BioGel A5m agarose gel column. Binding assay was performed at $4{ }^{\circ} \mathrm{C}$ by incubating ${ }_{125}$ I-r-proapoA-I $(10 \mu \mathrm{g} / \mathrm{ml})$ with human fibroblasts.

Results: Normal r-proapoA-I was distributed only in HDL fractions. In contrast to normal r-proapoA-I, r-proapoA-I (Lys 107 $\rightarrow 0$ ) and $\mathrm{r}$ proapoA-I Nichinan appear in HDL fraction and fraction where free r-proapoA-I presumely exist. Binding assay showed that r-proapoA-I $($ Lys $107 \rightarrow 0$ ) were bound to fibroblasts similar as normal r-proapoA-I, however r-proapoA-I Nichinan was $35 \%$ less bound to fibroblasts relative to normal r-proapoA-I.

Conclusion: Our data suggested that Lys 107 deletion and Glu235 deletion in apoA-I can affect the binding of the proteins to HDL particles. In addition, Glu235 deletion may also affect the interaction of apoA-I with cells.
175

HDL 受容体、SR-BI のコレステロール逆枟送系における 意

大阪大学分子制御内科

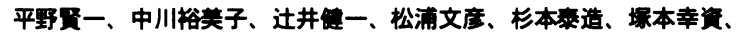

松山晃文、酒井尚庶、山下軤也、松湿佑次

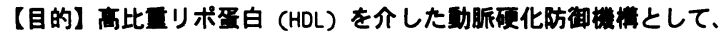

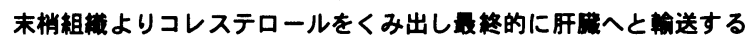
コレステロール逆枟送系 (RCT) が要である。我々は、槀HDL血

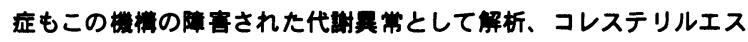
テル枟送蛋白 (CETP) 欠損症の病留に間して明らかにしてきた。一 方、昨年の本学会冬般大会において、近年クローニングされ HDL 受 容体と考えられる Scavenger receptor class B type I (SR-BI) の

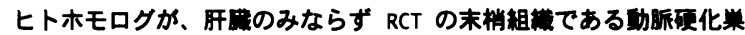
マクロファージにも発现していることを唚見、報告した。今回、

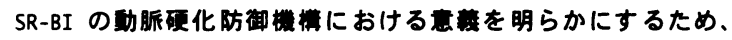
SR-BI の発现眫節について, in vitro (HepG2 細胞、ヒト学球由来 マクロファージ) 及び in vivo（ラビット）において模时した。 【方法】ヒトSR-BI の分布を、Northern bl ot 法、Western bl ot 法及ひ免疫粗灌化学的に模时した。コレステロール争荷に対する奻 果を、 in vitro 及ひ in vivoにおいて榙时した。

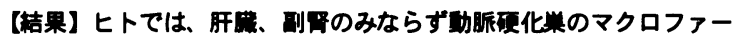
ジにもその発現か罣められた。また、コレステロール䒈荷により、 肝細胞ではその発現が減少、マクロファージでは墙加した。

【結㫻】SR-BI は、RCT のターミナルである肝器のみならず第一段 膄であるマクロファージにおいても発现していたが、コレステロー

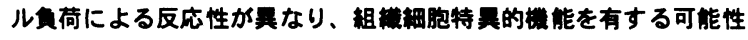
が示唆された。

\section{6}

糖尿病患者におけるLPL遺伝子多型（Ser447Ter）上 血清脂質および冠動脈硬化症との関連

順天堂大学循環器内科 澤野真人 渡辺嘉郎 岩間義孝 島田和典 圭野浩司 代田浩之 山口 洋

【目的】近年、LPL Ser447Ter 変異 (exon9) と高HDL-C上の)関 連が報告されている。今回我々は、低HDL-C血症を来しやすいと考 えられる糖尿病患者において、この変異の血清脂質に及ほす影響に ついて娭討した。

【方法】対象は当院で冠動脈造影検查を受けた糖尿病患者 99 例（男性81例、平均年齢61歳、CAD+83例）。血清脂質は早朝空腹 時に採血を行い測定、Ser447Ter遺伝子多型はPCR-RFLP法で決定し た。

【結果】（1）Ser447Terの出現頻度はCG:10例（変異群）, CC:89 例（野生群）であり (Allelic frequency 0.05)、糖尿病患者における この変異の頻度は、当科での一般健診者の頻度 (Allelic frequency 0.142）と比べ有意に低頻度であった（P<.05）。（2）血清脂質に おいて変異群は野生群に比べ有意にHDL-Cが高く、またTGが低い 傾向を認めた（HDL $61 \pm 18$ vs $40 \pm 12 \mathrm{mg} / \mathrm{dl} P<.0001$ [mean $\pm \mathrm{SD}$ ], TG $128 \pm 73$ vs $172 \pm 90 \mathrm{mg} / \mathrm{dl} \mathrm{P}=0.1$ ）。（3） HbAlcは変異群,野生 群間で有意差を認めず（CG 7.4 $1.1 \%, \mathrm{CC} 7.1 \pm 1.5 \%$ ）、この変異 の効果は糖尿病のコントロールとは独立したものと考えられた。

(4) CG多型の頻度はCAD+群において6\%（5/83）、CAD-群で31 \%（5/16）とCAD+群で有意に低頻度であった（P<.01）。

【結論】Ser447Ter遗伝子多型は、糖尿病患者においても HDL-Cの上昇と関連し、抗動脈硬化的に働くことが示唆された。 
177 アポE2由来ヒトマクロファージは、TG-richリポ蛋白と oxi-LDLに対するcholesterylester合成能を有意に元進させる

川崎医科大学糖尿病内科 斉藤美恵子、街藤雅昭、加来浩平

[目的]TG-richリポ蛋白の主要䅜成蛋白であるアポEには寈伝的多 型性(E2,E3,E4)が存在し、アポE2は川型高脂血症、高レムナント血 症、高TG血症と関連している。今回我々はアポE2を有する者、ア ポE3/3を有する者よりマクロファージを得て、TG-richリポ蛋白 (TRL)およびoxidized LDLの、アポE genotype別マクロファージに 対するコレステロールエステル合成能に及ほす影響を検討した。 [方法]アポE3/3遺伝型を有する健常者、アポE2遺伝型を有する健 常者よりヒト単球をBoyumの方法により分離し、マクロファージを

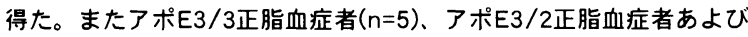
アポE3/2高脂血症者 $(n=5)$ の血鼎より超遠心法にてTRLを分離採取 しマクロファージ培食液中 $100 \mu \mathrm{g} / \mathrm{ml}$ chol湌度に調整し24時間培 責し ${ }^{14}$ Cーオレイン酸とincubationし、細胞中への ${ }^{14}$ Cコレステロー ルエステルへの取り込み能を検討した。[結果]アポE2マクロファ 一ジはアポE3/3マクロファージに比べてE3/2正脂血症者由来TRL に対するコレステロールエステル合成能を六進させ $0.306 \pm 0.011$ $0.257 \pm 0.024 \mathrm{n}$ mole $/ \mathrm{mg}$ cell protein $)(p<0.01)$ 、またアポE3/2高脂 血症者由来TRLに対するコレステロールエステル合成能を最も有意 にえ進させた $(0.526 \pm 0.021: 0.481 \pm 0.113 \mathrm{n}$ mole $/ \mathrm{mg}$ cell protein ) ( $p<0.001)$ 。E3/3正脂血症者由来TRLでは有意差はなかった。ま た、アポE2マクロファージはアポE3/3マクロファージに比べて oxi-LDLに対するコレステロールエステル合成能をえ進させた( $0.533: 0.411 \mathrm{n}$ mole $/ \mathrm{mg}$ cell protein )

[結諭]アポE2マクロファージはアポE3/3マクロファージに比べ てコレステロールエステル合成能をえ進させる。アポE2マクロフ アージのatherogenicityが示唆された。

\section{8 脂肪酸合成と細胞增殖}

帝京大学内科前田朝美、藤巻祐子、森 正樹、 福田良昭、堀江栄子、藤田美峰子、木下誠、寺本民生

【目的】肝細胞の再生増殖期に一過性の細胞内脂肪蓄積 が観察されており、細胞増殖に脂質が重要な役割を果たし ている可能性が示唆される。我々は本学会でこの再生増殖 期に細胞内脂肪酸(FA)の合成え進とトリグリセリドの合成 六進を確認し、報告してきた。本研究では肝細胞增殖期に 細胞内FAの合成え進を確認するためFA合成酵素 (FAS) 活性を測定した。また、FAS 阻害物質添加の細胞増殖に 及ぼす影響について検討し、さらに外因性脂肪酸の影響に ついても検討した。【方法】Wistar 系雄性ラットを用い 部分肝切除後 0,1,2,7 日後のFAS活性をBut t erworth, Kat i yar らの方法で測定した。次に初代培暮肝細胞を用い て、培䓹液にFAS阻害剂のCerul eninを添加し2 時間躬置 し ${ }^{3} \mathrm{H}$ チミジンを添加、DNAへの取り込みで細胞の増殖率を 推定した。また、Cerul enin存在下にオレイン酸、リノー ル酸を0.5,1.0mMの浱度で添加し同様に肝細胞の増殖率を 検討した。【結果】FAS 活性は部分肝切除後2日目に最高 值となり、術前の約3 倍まで有意に上昇していることが確 認された。Ceruleninを添加すると脂肪酸合成の抑制とと もに細胞增殖率も有意に約35\%減少した。Ceruleninで 抑制された細胞增殖率はオレイン酸、リノール酸を $0.5 \mathrm{mM}$ 添加しても回復しなかったが、 $1.0 \mathrm{mM}$ 添加するこ とで完全に回復した。【結論】脂肪酸の存在が細胞增殖に 重要な役割をもつことが示唆された。
179

アテノゥイルスを用いたヒトリポ蛋白リパーゼ通伝子紫入 による实呤的高脂血症の治病

$\begin{array}{lll}\text { 1) 九州大学第三内科 } & \text { 2) Baylor College of Medicine }\end{array}$ 小林 邦久 ", 梅田 文夫 "), 名和田 新 "), Lawrence Chan ${ }^{2)}$ 【目的】リポ蛋白リパーゼは triglyceride-richなリポ㔻白を加水分解 する律速蟀秦である. 我々はマウスにおけるアポ蛋白E欠損

(apoE-I-) およひ LDL 受容体欠損 (LDLR-I-) にともなった高脂血

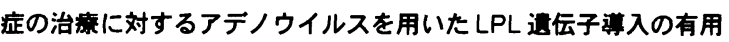
性について検封した.【方法】通常の方法によりヒトLPL CDNAを 含むリコンビナントアデノゥイルス (AdhLPL) を作成した. コン トロールウイルスにはルシフェラーゼウイルス (AdLuc) を用いた 【結果】AdhLPL を感染させた $C H O$ 細胞は活性型の LPL を分泌し た $(73 \mathrm{mU} / \mathrm{ml})$. AdhLPLを投与した野生型マウス (wt) の肝篮て は, LPL mRNA が発現し, 肝䓠における活性は $88.3 \mathrm{mU} / \mathrm{ml}$, ヘパ リン静注後血翡中の活性は $116.1 \mathrm{mU} / \mathrm{ml}$ であった. AdhLPL 投与に

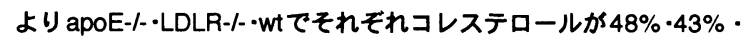
$25 \%$ 低下し，中性脂肪は $63 \% \cdot 40 \% \cdot 70 \%$ 低下した. VLDL/カイ ロミクロン分雨において apoE-/-・LDLR- - -wt でそれぞれコレステ ロールは $83 \% \cdot 84 \% \cdot 58 \%$ 低下しており, 中性脂肪は $92 \% \cdot 86 \%$. 84\%低下していた. AdLucを投与したマウスにおいてはLPL活性 ·

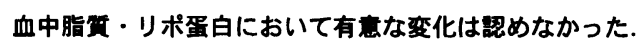

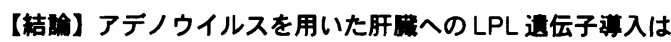

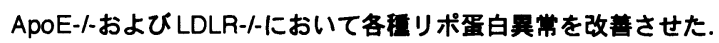

180 ACAT-1欠損腹腔マクロファージにおけるリポタンパク代 謝の検討

東京大学大学院医学系研究科 代謝栄養病態学

北峰哲也、石橋 俊、野牛宏晃、大須賀汻一、Stephane Perrey、 鬼沢隆一、陳 忠、田村嘉章、矢作直也、塩之入太、飯塚陽子、 大橋 健、原田賢治、後藤田貴也、島野 仁、山田信博

【目的】ACATKOマウスの腹腔マクロファージ (MPM)の cholesteryl ester formationは完全に抑制されている事を前回報告し た。今回、MPMを用い、(1)efflux、(2)lipoprotein degradation お よび(3)細胞内コレステロール(Cho)含量の測定を行い、MPMの泡 沫化とACATの関連を検討した。【方法】野生型マウス $(+/+)$ およ びACATKOマウス (-/)から thioglycolate-elicited MPMを採取し、 LPDS添加のDMEMで36時間培養した後、実験に用いた。(1) $\left.{ }^{3} \mathrm{H}\right]-$ cholesteryl oleateで標識したLDL受容体欠損マウス由来 $\beta$-VLDL、 ヒト acetylated LDL(AcLDL)で泡沫化させ、24時間後より、25 $\mu \mathrm{g} / \mathrm{ml} \mathrm{HDL}$ 存在下、非存在下で細胞外へ分泌された放射能を測定

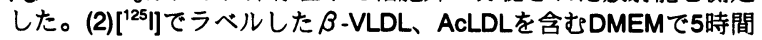
培養し、培養液中に放出されたタンパク質断片および細胞内放射 能を測定した。(3) $20 \mu \mathrm{g} / \mathrm{ml}$ の $\beta$-VLDLで、5時間培養し、細胞内 Cho含量を蛍光法にて測定した。【結果】(1)effluxは+/+および-/ の間で 5 時間、24時間とも有意な差は認められなかった。(2) lipoprotein degradationおよびcell associationにおいて+/+と-/-間で 有意な差は認められなかった。(3)細胞内の遊離型Choは+/+および

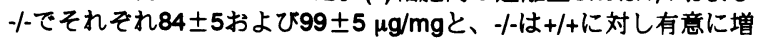

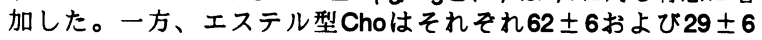
$\mu \mathrm{g} / \mathrm{mg}$ と、ー $/$ は+1+に対し有意に低下していた。【結論】リポタン パクの取り込みと分解およびCho effluxには+/+と-/-で差を認めず、 細胞内に取り込まれたChoは-/-ではエステル化を受けない為、遊離 型の形で細胞内に蓄積すると考えられた。 


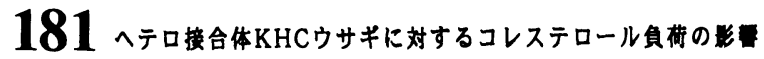

(侏以ムラ中央研究所 ${ }^{1)}$ 、国立健康 - 栄美研究所 ${ }^{2}$



松本明世2 ${ }^{2}$ 、近藤和雄 ${ }^{21}$ 、板倉弘重 ${ }^{2)}$

【目的】高脂血症は心血管系疾患の要因となっている。そこで、 我々はコレステロール負荷に対する感受性を知る目的で、雌また は雄性のLDLreceptor欠損へテロ接合体ウサギ(KHCウサギ)、日 本白色種ウサギ(JWウサギ) を用いて血清生化学的・病理組織学 的・肝楉における脂質代謝関連遺伝子の発現を検捨した。

【方法】雄性及び倠性のJWウサギまたはKHCウサギに対して普


間毎に経時的に採血し血清生化学的パラメーターを測定した。ま

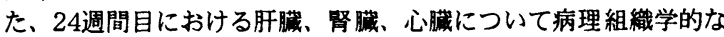
検討と胸部大動脈弓部における称状硬化病変発生面積比について も検討した。更に、肝蔵におけるApoB,ApoE,LDLreceptorの遺

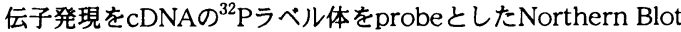
Hybridization法により検討した。

【結果及び考察】普通飼料を与えて飼育した全てのウサギでは、 24调間血中コレステロールの平均値は增加しなかった。しかし、


ロールの平均值は、雄性JWウサギでは $69 \mathrm{mg} / \mathrm{dL}$ 、崔性JWウサギ では $236 \mathrm{mg} / \mathrm{dL}$ 、雄性 KHCウサギでは $119 \mathrm{mg} / \mathrm{dL}$ 、雌性 $\mathrm{KHC}$ サギでは674mg/dLであった。血中リン脂質も血中コレステロー ルと同様のパターンであった。更に、大動脈弓部における强状硬 化病変は雄性JW、KHCウサギのいずれにおいても認められなかっ

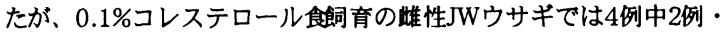
甠性KHCウサギでは全例で强状硬化病変が認められた。

以上の結果より、KHCウサギはJWウサギに比べてコレステロー ル負荷の影響を受けやすく、また、雄よりも继ウサギの方がより 脂質に対する感受性が高いことが示唆された。

\section{2 家族性複合型高脂血症における \\ リポ蛋白リパーゼの検討}

千葉大学第二内科 安房医師会病院 ${ }^{1}$ 済生会船橋済生病院 $^{2}$

平 晃一 武城英明 小林淳二 森崎信尋 青木 謹

原 久弥 ${ }^{1}$ 梅園 忠 $^{1}$ 篠宮正樹 $^{2}$ 鳳藤 康

【目的】家族性複合型高脂血症(FCHL) はIIb型高脂血症を呈する ことを特徵とし、虚血性心疾患の主要な原因の一つである。前回 我々はFCHL患者において頝動脈内膜中膜複合体肥厚度が六進し ている可能性を示した。これまでにFCHLの成因としてリポ蛋白 リパーゼ(LPL)やアポ蛋白遺伝子群との関連が注目されている が、その病態はほとんど明らかになっていない。今回我々は我が 国におけるFCHLの病態および成因を解明する目的でFCHL患者 におけるLPLについて検討した。【方法】対象は千葉県安房地区 FCHL32家系(FCHL群, $\mathrm{n}=32$ ) である。FCHL群と年齢、男女比、 BMI、血清総コレステロール(TC)、LDLーコレステロール(LDLC)およびトリグリセライド(TG)値を一致させた II b 型高脂血症患 者を対照(nonFCHL群, n=42)とした。ヘパリン静注後血奬中LPL 活性はTritonX-100で乳化したTrioleinを基質として測定した。 LPL蛋白量は抗LPLモノクローナル抗体を用いたサンドイッチ EIA法にて測定した。【結果】FCHL群の血清脂質値は $\mathrm{TC} 230 \mathrm{mg} / \mathrm{dl} 、 \mathrm{LDL}-\mathrm{C} 138 \mathrm{mg} / \mathrm{dl} 、 \mathrm{TG} 255 \mathrm{mg} / \mathrm{dl} 、 \mathrm{HDL}$-コレス テロール(HDL-C) $46 \mathrm{mg} / \mathrm{d}$ であり、nonFCHL群に比べHDL-C は有意( $\mathrm{p}<0.05)$ に低值だった。FCHL群におけるヘパリン静注後 LPL蛋白量は $177 \mathrm{ng} / \mathrm{ml}$ であり、nonFCHL群に比べ有意に低値 だった $(227 \mathrm{ng} / \mathrm{ml}, \mathrm{p}<0.005)$ 。またLPL活性は $7.75 \mu \mathrm{mol} / \mathrm{ml} / \mathrm{h}$ で あり、non FCHL群に比較し低值傾向を示した $(8.88 \mu$ $\mathrm{mol} / \mathrm{ml} / \mathrm{h}$ )。【結論】我が国におけるFCHLの病態にLPL異常が 関与する可能性がある。(本研究は厚生省原発性高脂血症調查研究 班(班長北徹)研究の一部である。）
183

L P L 逢伝子ヘテロ变暴( ${ }^{6}{ }^{1} \mathrm{~T}$ y $\left.r \rightarrow s t o p\right)$ を示

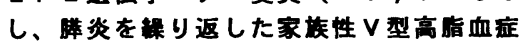

川崎医科大学榙尿病内科、高田中央病院 ${ }^{\prime}$ 、北海道大学医学 部區床検查医学 ${ }^{2}$ 加来浩平、漕上茂 1 、千菜志 ${ }^{2}$

[目的］家族性 V型高詣血应の成因に間してはいまだ不明の 点が多い。リボ蛋白リパーゼ（LPL）逢伝子のヘテロ变暴

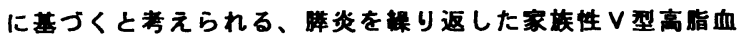

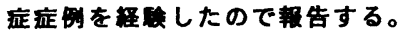

[症例] 50 オの女性である。31才の時、急性睡炎を舞症 し、某医に入院。詳啁は不明。45才の時、某医にて高トリ

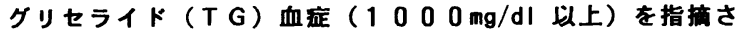
れたか、とくにそれに対して治剚は受けていなかった。時々、 背部蔽があった。48才の時、夕食に油物を食べた。翌朝、 心高部来が持桲し当院内科を受骖した。血中アミラーゼ值か $28231 \cup / 1$, 白血球 21600 と高值であり、急性膦 炎の詅断にて入院した。遇院啳、T G 值が高值のためベサフ ィブラートを内服していた。外来では血中ＴＧ直は２２１～ $1229 \mathrm{mg} / \mathrm{dl}$ と推移していたか、その滕膦炎の発症はなか

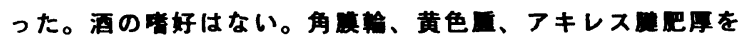
認めない。家族歴は同胞 4 人のうち 3 人が高T G 血应 ( 10 $00 \mathrm{mg} / \mathrm{dl}$ 以上) であった。血策 T G $741 \mathrm{mg} / \mathrm{dl}$ ，コ レステロール $164 \mathrm{mg} / \mathrm{dl}, \mathrm{HDL}-\mathrm{C} 24 \mathrm{mg} / \mathrm{dl}$, ア

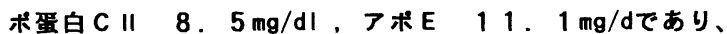

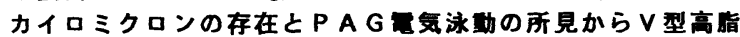
血症と崄断された。ヘパリン負荷後 L P L は $102 \mathrm{ng} / \mathrm{ml}$ と

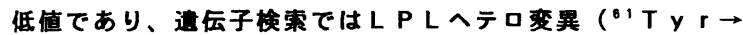
$s t \circ p)$ であった。

[蛣諭] L P L 速伝子ヘテロ変暴( ${ }^{61} \mathrm{~T}$ y $\left.r \rightarrow s t o p\right)$ は 家族性 V型高涽血症の原因の一つとして考えられる。

184 CETP 遺伝子变買/多型の虚血性心聅炰、頝動脈 硬化に対する影響

金沢大学保健学科検查技術 ${ }^{2}$ 、第二内科 2 、高知県衛生研究所 3 、大阪 㭘立成人病センタ一集団検診第 I 部 4 、金沢大学病院総合診療部 5 稲津明広 ${ }^{2}$ 、黄 志平?、寺田有美子!、西村佳子、水野美保子? 楃波康二?、森山ゆり、岡村智教、小泉順二5、馬㴊 宏 ${ }^{2}$

[ 目的 ] CETP 欠損と動脈硬化症との関係を地域住民の遺伝疫学 調相により明らかにする。[ 刘象と方法] 高知県野市町の高柃男


中外)とCETP遗伝子変異/多型（エキソン 15 機能多型 D442G，1 ントロン1多型 TaqIB，イントロン9多型 BamHI）の頻度を決定し た。安静時心電図異常、虚血性心疾患、頚動脈硬化（超音波診断） との関係を検討した。[結果 ] D442G,TaqIB 通伝子型はそれそれ 有意に血清 CETP 値に関連し (ANOVA $P<0.0001, P=0.02$ )、 BamHI は有意でなかった $(P=0.22) 。 D 442 G$ ヘテロ 28 例 $(10 \%)$ ではCETP $1.6 \pm 0.4 \mu \mathrm{g} / \mathrm{ml} （ D 442 \mathrm{G}$ なし2.3 $\pm 0.6 ）$ と低値を示し、 TaqlB +/+（切断あり） 85 例 (33\%) では $2.4 \pm 0.7 、 B a m H I+/+5$ 例 $(2 \%)$ では $2.7 \pm 0.3$ と高値を示した。血清 CETP値に対する標 準回帰係数は、 $D 442 G \wedge テ \square-0.37(P<0.0001), T a q 1 B+/+0.18$ $(P=0.002), B a m H I+1+0.10 \quad(P=0.08)$ であり、 D442G と TaqIB $+/+$ の遗伝子型による分散奇与率は $16 \%$ であり、独立した効果を示 した。血清HDL-C 值は各遗伝子型間で有意差を認めなかった。ST-T 虚血性変化の有所見率は D442G 群で 3 倍に増加していたが ( $21 \%$ 対 D442G なし $7 \%, P=0.006$ ）、TaqlB と BamHIでは有意差を認めな かった。虚血性心疾患の有病率と頝動脈硬化スつアは D442G,TaqIB, BamHI のいずれの逼伝子型とも有意差を認めなかった。[結論 ] ST-T虚血性変化とD442Gの関連が示唆された。 
185 CETP景伝子Taq IB多型の血清CETPおよび脂質に及ぼす影票

広島大学第一内科、同臨床検查医学・、エーザイ笕波探索研究所“* 豊田康影 林幸三 武生英一郎 野村勝彦 片野高広 大田和子 新宮哲司 平賀敬己 大谷晴美 松浦秀夫 椐山梧朗 神辺丧之・ 佐藤俊孝”*

【目的】日本人健常男性におけるコレステリルエステル転送蛋白 (CETP)遣伝子のTaq IB多型の頻度と血清CETP量および脂質レベルに 及ほす影霓を検討する。【対象と方法】検診を受診した健常人男性 173名を対象として空腹時採血を行った。血清脂質は醉素法により、 血清CETP量はELISA法により測定した。道伝子多型は、全血より抽 出したDNAの目的塩基配列をPCR法により增幅したのち Taq I処理を 行いアアガロースゲル電気泳動により分類した。【結果】Taq IB多型 はB1B1 60名(34.7\%), B1B2 87名(50.3\%), B2B2 26名(15.0\%)と、日本人 男性における分布頻度は欧米の報告にほぼ一致するものであった。 血清CETP量はB1B1 > B1B2 > B2B2の順に高值を示した (B1B1 vs. B2B2, B1B2 vs. B2B2; p< 0.05)。血清HDL-Ch値はこの逆順に高値を 示す傾向がみられた(B1B1; $55.7 \pm 10.1 \mathrm{mg} / \mathrm{dL}<\mathrm{B} 1 \mathrm{B2} ; 58.2 \pm 12.7<$ B2B2; 58.7 12.2)が有意差はなかった。血清HDL-Ch值を低下させる 要因である乫煙と上昇させる要因である䣄酒の影第を除外するため、 喫煙者および 1 日25gを越えるアルコール摄取者を除いて検討した場 合、B1B1ではB2B2より有意に血清HDL-Ch值が低値であった。血清 総コレステロール值、トリグリセライド值に有意差は認めなかった。

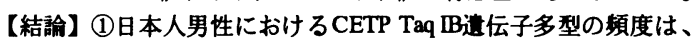
欧米の報告とほほ同粎で人種差は認められなかった。

(2)CETP Taq IB Genotype B1ではB2より血清CETP量が高值となる ことにより血清HDL-Ch值を低下させている可能性が示唆された。

\section{6} 日本人における血清 CETP 量と遭伝子多型の関連 （株）ビー・エム・エル研究開発本部、大阪大学第 2 内科” 長野誠、伊藤 真由芙、提箸 幸子、鲸岡 健、服部 浩明、 江頭徹、山下 静也”、丸山貴生”、松沢 佑次“

【目的】 CETP 遭伝子多型である Intron7+8 (C/T) および aa405 (I/V) と血清 CETP 蛋白量および活性との関連を検討した。

【方法】血清 CETP 蛋白量は 2 種類のモノクローナル抗体を用いたサ

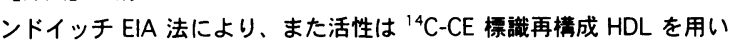
た CE 転送能により測定した。CETP 逢伝子多型および变異解析は白 血球より得た DNA を用いPCR-DGGE 法および-RFLP法により行った。 【結果】 CETP 遗伝子 common 変異が認められなかった 129 名にお ける Intron7+8 多型の出現頻度は C/C 56 名 (43\%)、C/T 59 名 (46\%)、T/T 14 名 (11\%) であり、C/T多型のアレル頻度は、.66/.34 であった。また、aa405 多型は1// 25 名 (19\%)、I/V 60 名 (47\%)、 V/V 44 名 (34\%) であり、I/V 多型のアレル頻度は、.43/.57 であ つた。Intron7+8 多型における CETP 蛋白葍は、 C/C、C/T、T/T 群 それぞれ男性では $2.1 \pm 0.6 、 1.8 \pm 0.7 、 1.7 \pm 0.2 \mu \mathrm{g} / \mathrm{ml}$ 、女性で

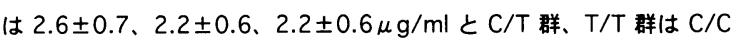
群に比して低值傾向であった。活性も同様な傾向であった。一方、 aa405 多型では、蛋白量および活性ともに V/V 群がやや低值を示す 傾向であった。また、Intron7+8 T/T 群 14 名中 11 名は aa405 V/V を、3名は $1 / V$ を有するなど、2 つの多型間の T-V の出現パターン に弱いながらも傾向がみられた。

【結語】CETP遭伝子多型と血清 CETP 量に関係が認められた。
187 CETP遗伝子発現に及ぼす脂肪酸不飽和度の影稫

国立健康 - 栄暴研究所 ${ }^{1}$ ，お茶大 ·生活環境研也 ${ }^{2}$ 平野玲子 ${ }^{1,2}$, 近藤和雄 ${ }^{1}$, 五十嵐修 ${ }^{2}$, 板食弘重 ${ }^{1}$, 松本明世 ${ }^{1}$

【目的】CETPはコレステロール逆転送系に関わり、リポ蛋白代謝， 特にHDL 代謝を規定する重要な因子である。脂肪酸の各種脂質代謝 関連遺伝子への発現制御作用は知られているが, CETP 発現への効 果についてはほとんど明らかにされていない。本研究では，CETP 発現に及ほす長鎖脂肪酸の調節作用をmRNAレベルおよび蛋白レベ ルから検討した。【方法】HepG2 細胞の培苃液中に、10\%BSA に懸濁した炭素数 18 以上の長鎖脂肪酸; ステアリン酸, オレイン酸, リノール酸、 $\alpha, \gamma$-リノレン酸、アラキドン酸(AA), EPA, DHA を終 搌度 $0.5 \mathrm{mM}$ となるように添加し，48 時間 incubation した。細胞か $ら$ AGPC 法で Total RNA を調製し，CETP cDNA fragment(260bp) をブローブとして Northern Hybridization 法で mRNA を検出し， BAS2000により定量化した。また，培拻液中に分泌された蛋白量 をELISA 法により測定した。【結果】長鎖脂肪酸の不飽和度が增 加するに従い，CETP mRNA 発現量は低下し，特に不飽和度 4 以上 のAA，EPA，DHAではコントロールの発現量に比し，50\%以上の 有意な低下を認めた。蛋白レベルの検討でもAA，EPA，DHA 処理 により，培蛽液中への CETP 分泌量は有意に低下することを認めた。 【結語】長鎖脂肪酸は CETP の遺伝子レベルおよび蛋白レベルにお ける発現を調節し，長鎖脂肪酸の不飽和度が高いほど，CETP 発現 を抑制することが示唆された。

188 精尿病性督症におけるコレステロールエステル転送蛋白の 検討

東京女子医科大学糖尿病センタ一，東京医科菌科大学第三内科* 河原玲子冨樫倫子 吉野正代 宮前至博 渡部ちづる 石川紀 子岩本安彦 田中明*

【目的】コレステロール転送蛋白 (CETP) はHDL 中のコレステ ロールエステルを他のリポ蛋白に転送し脂質交換を促進する．1 ンスリン依存型糖尿病における堅症では CETP 活性が增加したと 報告されているが，インスリン非依存型糖尿病（NIDDM）の堅 症における CETPについてはまだ知られていない，そこで NIDDM 患者の CETP を測定して，惄症の進行や，低 HDL 血症 の成因に関与するか否かを検討した。

【方法】対象はNIDDM 男性 56 名，女性 33 名, 計 89 名で, 年齢 $55.4 \pm 10.2$ 歳, BMI $23.9 \pm 4.9 \mathrm{~kg} / \mathrm{m}^{2}$, 食事療法 9 名, 経口棛 32 名, インスリン 48 名であった.これを早朝尿で正常アルブミン尿群 31 名，微量アルブミン尿群 29 名，蛋白尿群 16 名，惄不全群 13 名の 4 群に分けた。早朝空腹時採血で血清 CETP 量を ELISA 法 （CHUGAI）で，脂質分画をHPLC法で測定した.

【結果】年齢, BMIは 4 群間で差がなかったが, HbA1C は正常ア ルブミン尿群で高く，HDLは蛋白尿群，腎不全群で他の 2 群より 低値であった。 その他の脂質は 4 群間で差がなかった。

CETP 量は督機能の順に $5.02 \pm 1.95 \mu \mathrm{g} / \mathrm{ml}, 5.97 \pm 1.74 \mu \mathrm{g} / \mathrm{ml}$, $5.75 \pm 2.13 \mu \mathrm{g} / \mathrm{ml}, 6.27 \pm 2.12 \mu \mathrm{g} / \mathrm{ml}$ で, 督不全群で高值傾向 であったが、これら 4 群間の差は推計学的に有意ではなかった。

CETP 量と年齢, BMI, 各脂質, リポ蛋白との間に有意な相関 関係はみられなかったが, HbAlc とは軽度の負の相関を有した $(\mathrm{r}$ $=-0.220, \mathrm{p}<0.05)$.

【結論】CETP 量は，NIDDM でとくに留障害を有するものに高 值傾向であったが，低 HDL 血症との関連は認められなかった。 
189 トリダリセリト枟送を選択的に阻害する抗 CETP 単つローン 抗体 14-8F $の$ conformational epitope $の$ 決定 名古屋市立大学医学部生化学 । 横山信治 第一化学筑波研究センター 小堀樹一郎、齊藤和典、真銅満久

[目的] 家鬼 CETP に対する単クローン抗体 14-8F はトリグリセリ ト（TG）枟送を阻害するがコレステリルエステル（CE）枟送を阻 害せず、ヒト CETP に対しても同様の交叉反応を示す（Ko et al., JBC 269，18206，1994）。この抗体の epitope を決定するため、家 鬼及びヒトの CETP の断片ペブチドを固相法により合成して抗体へ の反応性を検即した。

[方法] ペプチドと抗体の結合は、プラスチックに固着したペプチ ドを 14-8Fに反応させ、さらに peroxidase 橿識した抗マウス IgG山 羊抗体を加えて発色反応させて測定した。

[結果] 14-8F の epitope は家鬼 485 - 493 (EHLLVDFLQ) または ヒト 465 - 473 (KHLLVDFLQ) を要求するが (core epitope) これ のみでは抗体と反応せず、さらにその $\mathrm{N}$ 末側または C 末側への 1 残 基以上の延長を必要とした。この延長による反応性獲得は、特に N 末側では残基特異性が低かった。Core epitope か両親媒性ヘリック スを形成した時、その両端は親水性・疎水性の境界に位嘈する。従つ て、N または C 末側への延長は core epitope の両親媒性ヘリックス 䅜造を安定的に発現するために必要であることが示唆され、これに よって epitopic conformation が誘道されることで 14-8F と反応性か 生ずることが推論された。これらの結果は、CE、TG 両脂得の轱送 を阻害するとされる抗ヒト CETP 単クローン抗体 TP2 の epitope 460D プラス 463 - 475 (FPEHLLVDFLQSL) と比較して 14-8F で は抗体の結合の程度か「浅い」ことが想定され、これか親和性の弱 い TG 轱送反応を選択的に阻害する機序であると結論づけられた。

\section{Determination of PLTP mass by sandwich ELISA}

（株）ビー・エム・エル 研究開発本部

Department of Biochemistry,

National Public Health Institute, Finland*

岡 智一郎、伊藤 真由美、江頭 徹、服部 浩明

Matti Jauhiainen*、Jari Metso*、Christian Ehnholm*

【目的】 Phospholipid transfer protein (PLTP)は、コレステロー ル逆転送系に関与する蛋白の一つと考えられているが、そ の臨床的意義については明らかでない。血中 PLTP の検討は 従来、 phosphatidylcholine (PC) liposome から $\mathrm{HDL}_{3} へ$ へ PC transfer 活性の測定によって行われている。しかし PLTP の 蛋白量を測定する系の報告はない。今回我々は血中の PLTP 量を定量するサンドイッチ ELISA の開発を試みた。【方法】 ヒト PLTP CDNA を導入した CHO 細胞株に発現させたりコ ンビナント PLTP (rhPLTP)を抗原として、マウスに免疫し、 PLTP を特異的に認識するモノクローナル抗体を作製した。 サンドイッチ ELISA 測定系は、固相にモノクローナル抗体 \# 114、検出にビオチン化したモノクローナル抗体\#113を 用いて構築した。測定は rhPLTP をスタンダードに、界面活 性剂含有 PBS で 200 倍希釈したヒト血清を用いた。【結果】 本サンドイッチ ELISA は $0.2-10 \mu \mathrm{g} / \mathrm{ml}$ の PLTP を測定可能 であり、日内及び日差変動は CV $10 \%$ 以下であった。健常者 53 名の血中 PLTP 量は、 $3.6 \pm 0.7 \mu \mathrm{g} / \mathrm{ml}$ (平均士標準偏差) であった。【結論】ヒト血中 PLTP を定量的に測定可能なサ ンドイッチ ELISA を開発した。この測定系はヒトPLTP に 特異的であり、再現性も良好であることから PLTP の臨床的 意義の研究に有用と思われる。
191

ヒト全身諸䑏器ならびにマクロファージにおけるAcylCoenzyme A:Cholesterol Acyltransferase(ACAT-1)局在

坂下直実 ${ }^{1)}$, 宮崎 章2), 堀内正公2), 高橋 潔1)

1)熊本大学医学部病理学第二, 2)同 生化学第二

ヒト全身諸䑏器ならびにマクロファージにおけるAcyl-

Coenzyme A:Cholesterol Acyltransferase (ACAT-1)の局在を検 討する目的で、われわれは剖検例から得たヒト全身諸陸器の凍結 標本ならびに健常成人末梢血単球由来マクロファージを対象に、 ヒトACAT-1特異ポリクローナル抗体を用いた免疫組織化学、

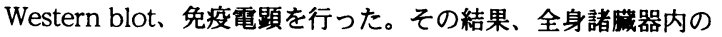
ACAT-1陽性像は (1)ステロイド集合㘂器(小腸上皮, 肝細胞), (2) ステロイドホルモン産生細胞 (副堅皮質細胞、顆粓膜/Leidig細 胞), (3)マクロファージとその関連細胞 (滤胞樹状細胞, 皮庙ラン ゲルハンス細胞), (4)その他 (神経細胞, 心筋細胞, 平滑筋, 中皮細 胞, 移行上皮, 気道上皮, 尿細管上皮, 甲状腺㵒胞上皮, 膵腺房細 胞, 前立腺上皮, 下垂体)に認められた。免度電顥の結果、培養七 トマクロファージでは、ACAT-1は粗面小胞体に局在していたが、 ACAT-1の基質であるコレステロールの負荷によって、約40\%の ACAT-1が粗面小胞体から細胞内小胞に移動した。Western blot による検討の結果、コレステロール負荷後もACAT-1蛋白レベル では細胞内の変動が起こらないことが明らかになった。以上の結 果から、ACAT-1はコレステロール/ステロイドホルモンの代謝 のみならず、全身諸濸器に普遍的に発現しており、基質であるコ レステロールの負荷によって、細胞内局在が変化することが明ら かになった。

192 Sulfonylurea剂glibenclamide(GB)はACAT阴管剂でもある

熊本大·薬、熊本大·医・生化

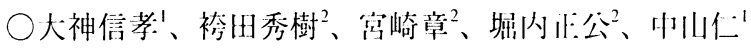

【日的】糖尿病治療薬であるGBがmacrophage $(\mathrm{M} \phi)$ の刖 質代謝に及ぼす効果について検討した。【方法】ヒト 単球-M $\phi$ 由来のTHP-1、マウス M $\phi$ 由来の $\mathrm{J} 774$ 細胞を用 い、(1)蛍光酵素法による細胞内のcholesteryl ester(CE)、 free cholesterol(FC)量の変化、(2) [ $\left.{ }^{3} H\right]$ oleate-BSAを用いた CE合成能、(3)ミクローム法、リポソーム再構成法 によるACAT活性の変化、(4)KM-10を用いたウェス夕 ンブロットでACAT蛋白量の変化について測定を行っ た。【結果】(1)GBは濃度依存的に細胞内のFCを増加 させCEを減少させた。(2)CE合成能も同様に抑制した。 (3)ACAT活性に対して明確な抑制効果を示した。 (4)ACAT蛋白量については影響を及ほささかった。

【結論】 GBはM $\phi$ の泡沫化を抑制し、そのACAT活性 も蛋白量を変化させずに抑制したことから、GBは ACAT 阻害剂でもあることが分かった。 
193 インスリン抵抗性動物での血管内皮 $\mathrm{NO} / \mathrm{O}_{2}$-産生異 常について

滋賀医科大学第三内科 西尾善彦, 柏木厚典, 篠崎一哉, 前 野恭宏,金澤昭雄,吉川隆一

【目的】我々はインスリン抵抗性を伴う高インスリン血 症動物では血管内皮よりの $\mathrm{O}_{2}$ 産生が六進して血管内皮 機能が障害されることを報告した。今回、異なった機序 によるインスリン抵抗性動物を用いて、血管壁でのNO および○一産生を測定し、インスリン抵抗性動物での血 管壁における $\mathrm{NO} / \mathrm{O}_{2}-$ imbalance $の$ 存在の普遍性について 検討した。【方法】インスリン抵抗性モデルとして Dラットを $60 \%$ 果糖含有飼料にて飼育した果糖食ラット 及び遺伝的にインスリン抵抗性を持つZuker Fatty (ZF)ラ ットを用いた。O2-産生はルシゲニン化学発光法にて、 NO産生はNO分析器を用いて行った。【結果】1)胸部大 動脈内皮よりの02-産生はCaイオノフォアー(A23187)に より果糖食ラットで2.9倍、ZFラットで3.2倍それぞれ増 加した $(P<0.01)$ 。2)A23187存在下での $0_{2}$-産生は果糖食 ラットで4倍、ZFラットで3.5倍それぞれの対照群に比較 して増加していた $(P<0.01)$ 。3)NO産生はA23187により 対照では有意な増加 $(P<0.05)$ を認めたが、果糖食ラット ZFラットではともに有意な増加を認めなかった。4） A23187存在下でのNO産生は果糖食ラットで対照の40\% にZFラットで34\%に低下していた $(P<0.05)$ 。【結論】 遺伝的要因あるいは環境的要因によるインスリン抵抗性 ラットモデルの双方において、内皮よりの02産生過剩 およびNO産生の低下を認め、インスリン抵抗性症候群 での血管内皮機能障害の原因として重要と考えられた。

194

HMGCOA逼元醅素阻害戍フルバスタチンの雌性家鬼動脈硬化 症におけるNO分泌促進作用及ひ抗動脈硬化作用

名古屋大学医学部老年科学 角大语、林登志雄、加納初世、浅井友香 子、 Navin Kumar Thakur, Muthuvel Jayachandran, 井口昭久

目的）卵巣摘出雌性（コレステロール食負荷）家鬼動脈硬化症におい てフルバスタチンが血清脂質改善作用以外に抗動脈硬化作用を持つか を検討した。

方法）卵笨摘出雌性ニュージーランド白色家鬼を1) 0.5\%コレステロー ル食群 (Ch群), 2)0.5\%コレステロール食+フルバスタチン (2mg/kg/day) 群(FI群) の二群に分け、12週間飼育後、採血し大動脈を摘出し血液生 化学、脂貫、脂質被酸化性、血管内皮機能及ひ動脈硬化病変（計測及 び免度組織)を検討した。

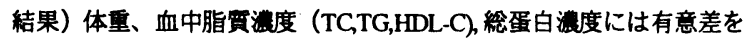
㪊めなかった。Flu群はCh群に比しアセチルコリン及びCa ionophore A23187によるNO分泌刺激反応、L-NMAによるNO分泌基稳反応が有意 に改善し、ニトログリセリンによる内皮非依存性弛緩反応には変化な かった。血管壁CGMP浥度も有意に上昇させた。弓部及ひ胸部大動脈 における動脈硬化面種には有意な差を認めなかったか、、マクロファー ジの染色部位は有意に減少した。血筹から分離したLDLのCuSO,によ る非酸化性も低下する傾向にあった。結論) フルバスタチンが血清脂 實に影帮のない投与量で、卵巣摘出崔性家鬼動脈硬化血管におき、 NO分泌改善作用をもち、硬化病変の安定化に寄与している。

結論) フルバスタチンは、卵巣摘出家鬼においても血清脂賈改善作用 以外に内皮機能改善、硬化病変安定作用を持つ。
195

動脈硬化の危険因子である高血圧、楉尿病、高脂血症では 血管内皮機能障害が生じ klotho mRNA の発現が低下している 群馬大学第 2 内科 斎藤勇一郎、中村哲也、相澤宏樹、松村鐜、 大山良雄、宇都木敏浩、倉林正彦，永井良三

京都大学腫癔生物学 鍋島陽一

テキサス大学病理学 增田浩明、須賀達夫、黒尾誠

【目的と方法】Klotho 欠損マウスは内膜の肥厚や中膜の石灰化を 特徴とする動脈硬化所見を示す。我々は、へテロ個体で血管内皮 細胞の NO 産生の低下が存在することを報告した。しかし、動脈硬 化の危険因子である高血圧、糖尿病、高脂血症の各病態における 血管内皮機能とklotho mRNA 発現の関係は不明である。本研究で は、自然高血圧発症ラット (SHR)、DOCA 食塩高血圧ラット、Dahl 食塩感受性ラットおよび高血圧症、糖尿病、高脂血症の合併する Otsuka Long Evans Tokushima Fatty (OLETF) ラットを用いて、腎 炡における klotho mRNA の発現低下と血管内皮機能障害が同時に 認められるか否かを検討した。【結果】 OLETF ラットの血桾 $354 \pm 44 \mathrm{mg} / \mathrm{dl}$ 、中性脂肪 $351 \pm 46 \mathrm{mg} / \mathrm{dl}$ であり、対照群（LET0）の血 糖 $156 \pm 14 \mathrm{mg} / \mathrm{dl}$ 、中性脂肪 $73 \pm 11 \mathrm{mg} / \mathrm{dl}$ より有意に高值であった。 各病態モデルラットでは、アセチルコリンによる胸部大動脈リン グ状標本の血管内皮依存性驰緩反応が対照群に比べ 有意に低下し ていた(表 1)。腎䐵におけるの klotho mRNA 発現も各病態モデル で低下していたが、内皮機能障害の最も強いDahl ラットでklotho mRNAの発現低下が目立った。【結論】Klotho 遺伝子は、動脈硬化 の成因のひとつである血管内皮機能の調節に重要な役割を果たし ている可能性がある。

表 1. 各病俧モデルラットの収縮期血圧とアセチルコリン $\left(10^{-} \mathrm{M}\right)$ による最大弛緩率

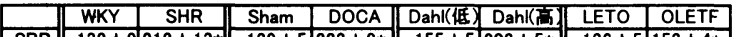

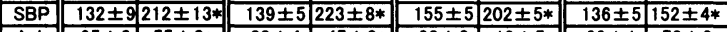


${ }^{*} \mathrm{p}<0.05$ vs 対照群. SBP; 収簿期血压, Ach;アセチルコリン (10-5) WKY; Wistar

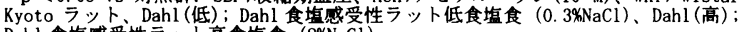
Dahl 食塩感受性ラット高食塩食 $(8 \% \mathrm{NaCl})$

\section{6 タバコ䨪水抽出洨を投与した远伝性高脂血症ウサキの 血管反応性の㚆化とビタミン $\mathrm{E}$ 投与の期}

武庫川女子大学薬学部・薬理学

○籠田智美、山口 優、中村一基、国友 勝

【目的】動脈硬化の危険因子とされる契煙の血管内皮機能への影䇾 を明らかにするため、ニコチン除去夕バコ煄水抽出液 (CSE) または ニコチンを遺伝性高脂血症 (WHHL) ウサギに長期投与し、種々動脈 に生じる血管反応性の変化と、それに及ぼすビタミン $\mathrm{E}(\mathrm{VE})$ 投与 の影䆄を検討した。

【方法】 2 ヶ月齢のWHHL ウサギに CSE $3 \mathrm{ml} /$ day の静脈内投与ま たはニコチン $0.5 \mathrm{mg} /$ day の皮下投与を行い、食㨁として $0.3 \% \mathrm{VE}$ 添加または無添加固形飼料を与えた。5ヶ月間飼有の後、胸部大動 脈、冠状動脈、叒動脈および頚動脈のリング状標本を作製し、マグ ヌス法により張力変化を記録した。

【結果】1) CSE 投与動物の胸部大動脈において、アセチルコリン $(\mathrm{ACh})$ に対する内皮依存性弛綬反応は減弱したか、その減弱はVE 処置により抑制された。2) 冠状動眽において、ACh に対する弛緩 反応はCSE 投与により增強したか、VE 処置により影響を受けなかっ た。3)叒動脈および頚動脈において、ACh に対する弛緩反応は CSE 投与により影䇺をうけなかった。4) 冠状動脈および堅動脈に おいて、ニトロアルギニン存在下の $\mathrm{ACh}$ に対する弛髣反応は CSE 投与により隇弱したが、その減弱はVE 処置により抑制された。5) ニコチン投与動物のいずれの動脈においても ACh に対する弛緅反 応に変化はみられなかった。

【考察】以上の結果、CSE 投与による一酸化窒素（大動脈）およ び内皮由来過分極因子（冠状動脈・叒動眽）の産生低下が VE 攝取 により抑制されること、ニコチン投与は血管反応に影響しないこと が明らかとなった。VEは夕バコ煙中のオキシダントにより生じる 内皮機能低下を防止できると考えられる。 
197 血管内皮細胞におけるリゾホスファチジルコリンによ るPyk2のチロシンリン酸化

神戸大学医学部第一内科 力武良行、川嶋成乃亮、竹下佐織、 井上信孝、横山光宏

【目的】カルシウム依存性チロシンキナーゼのPyk2は血球 系細胞や血管平滑筋細胞などにおいて種々の刺激により活性 化されることが報告されている。我々は、酸化LDL中に存在 するリゾホスファチジルコリン(LPC)が血管内皮細胞内カル シウムを上昇させることを報告したが、Pyk2がLPCにより 活性化されるか否かは明らかではない。今回我々は、血管内 皮細胞においてPyk2がLPCによりチロシンリン酸化される ことを見い出したので、その機序に関し検討した。【方法】 培養ウシ大動脈内皮細胞を用い、Pyk2のチロシンリン酸化 は抗Pyk2抗体による免疫沈降物を抗リン酸化チロシン抗体 を用いたウエスタンブロットにて検討した。【結果】LPCに よりPyk2は濃度依存性、時間依存性にチロシンリン酸化さ れた。カルシウムイオノフォアのA23187によりPyk2はチ ロシンリン酸化され、カルシウムキレーターのBAPTA-AM やEGTAの前処置により、LPCによるPyk2のチロシンリン 酸化は抑制された。また、phorbol esterによってもPyk2 はチロシンリン酸化され、 protein kinase C (PKC)の down regulationあるいは、PKC阻害剤のGF109203Xに より、LPCによるPyk2のチロシンリン酸化は抑制された。 cytochalasin Dにより細胞骨格を破壊すると、LPCによる Pyk2のチロシンリン酸化は抑制されたが、C3毒素処理や Rhoのnegative mutantの過剩発現によっては、チロシン リン酸化は抑制されなかった。【結論】血管内皮細胞におい てPyk2はLPCによりチロシンリン酸化された。LPCによる Pyk2のチロシンリン酸化はカルシウム及びPKC依存性であ り、またそれには細胞骨格の関与が考えられた。

\section{8}

血管平滑筋から産生される Vascular Endothelial Growth Factor (VEGF) による内皮保護作用機構

大阪大学加橉医学講座 烟茂樹、福尾恵介、須原敏充、荻原俊男

（目的）内皮細胞 (EC) に対する特異的増殖因子である vascular endothelial growth factor (VEGF) は、ASO の治療薬として注目され ているが、他方では、糖尿病網膜症などの血管新生を伴った病態 を誘導することが知られている。これに対して血管平滑筋などか ら生理的に産生される VEGF の役割は不明である。我々は、以前、 EC における、nitric oxide (NO) によるアポトーシスの誘導を VEGF が抑制することを報告したが、今回、この機序を明らかにする目 的で NO による p53 の誘導に対する VEGF の影響を検討した。 （方法）細胞培盖 : 七上脚帯静脈 EC を用いた。アポトーシスの検 出 : TUNEL 法による FACscan を用いた。Bcl-2、Bax および p53 の発現 : FACscan およびウエスタンブロット法を用いた。p53 DNA結合活性の解析 : EMSA 法を用いた。(結果) NO は ECに アポトーシスを誘導したが、この時アポトーシス促進蛋白である Bax の発現の促進と、抗アポトーシス蛋白である Bcl-2 の発現の抑 制を同時に伴った。これに対し、VEGF $(10-50 \mathrm{ng} / \mathrm{ml})$ は、このNO による Bcl-2 family 蛋白の変化を抑制した。また、血管平滑筋細胞 (VSMC) の培養上清は、NOによるEC のアポトーシスを抑制した が、この抑制作用は、VEGFに対する中和抗体によって消失した。 p53 はアポトーシスを誘導する癌抑制因子であるが、同時にこれ らの Bcl-2 family 蛋白の転写調節因子であるが、VEGF は NO によ る p53 蛋白の発現量には有意な影響を与えなかったが、p53の DNA 結合活性の NO による促進作用を有意に抑制した。以上の結 果より、VEGF は p53 を介した経路を抑制することによって NO によるアポトーシスを抑制することが示唆された。（結論）生理 的に VSMC から産生される VEGF は大量の NO による内皮傷害を p53 を介したアポトーシスを阻害することにより抑制する可能性 がある。

\section{佐賀医科大学・医・病理}

䣕黎青 佐藤敏美 徳永 藏

【目的、方法】動脈硬化病巣の発生・進展にLDLの蓄積が重要 な役割を果たしている.血中より内膜へのLDL移送経路は内皮細胞 のendocytosis と transcytosisが考えられる。昨年ヒト大動脈に存在 する大型多核のバリアント内皮細胞(MVEC)のLDLの取り込みは 約 5 倍多いことを報告した。今回LDL輸送に関係するバリアント 内皮細胞のcaveolin 発現を免疫学的に検討し、GoldーLDLの取り 込みを電影的に観察した。ヒト大動脈初代培養内皮細胞をアセ卜 ン固定し、抗ヒト caveolin モノクローナル抗体 (Clone C060, Transd Lab)、ローダミン標識二次抗体法で観察した。【結果】 MVECでは細胞表面に多数の微細顆粒状の caveolin が発現されて いたが、単核の典型的内皮細胞（TEC）では細胞あたり、面積あ たり共に少なかった。電顕的にLDLGold粒子は細胞内では単独で 存在するものと、小胞内に集族して認められる場合があり、後者 はvesicle 移送を観察しているものと思われた。【総括】MVECで は前回報告したように多数のLDLリセプターを介してendocytosis により取り込み亢進がおこるとともに、 transcytosisによっても盛 んにLDLを取り込んで動脈壁の脂質沈着に重要な役割を果たして いることが考えられた。

200 培堲血管内皮細胞における可溶性レクチン様酸化 LDL 受容 体(LOX-1)の産生

京都大学医学部老年科*、国立循與器病センター**

村瀬孝利*、久米典昭*、沢村達也 $* *$ 、真崎知生 $* *$ 、北徹*

【目的】レクチン様酸化 LDL 受容体(LOX-1)は血管内皮細胞にお いて、TNF $\alpha$ などの炎症性の刺激や、shear stress などにより発 現が強く誘導される事が示されている。今回我々は、TNF $\alpha$ で刺 激された血管内皮細胞の培養上清中に可溶性の LOX -1 分子が存 在することを見出し、その分子構造及び生成機序につき解析を行 った。【方法】 TNF $\alpha$ 刺激された培養ウシ大動脈内皮細胞(BAEC) 及び LOX-1 を強発現する $\mathrm{CHO}$ 細胞(BLOX-CHO)の培養上清を 用い Immunoblot を行った。BLOX-CHO の培養上清からイオン 交換カラム、ヘパリンカラムなどを経て可溶性 LOX-1 を精製し、 そのN末端アミノ酸配列を解析することにより可溶化に伴う LOX - 1 の切断配列を決定した。【結果】TNF $\alpha$ で刺激された BAEC の培養上清では濃度及び時間依存的に可溶性 LOX -1 が増加し、刺 激後 8 時間で検出可能となった。細胞表面蛋白を予めビオチン化 した細胞を培盖すると培義上清中にビオチン化された LOX-1 が 検出されたことから、可溶性 LOX-1 は細胞膜上の LOX-1 に由来 すると考えられた。BLOX-CHO 細胞の培養上清から可溶性 LOX -1 を精製し、 $\mathrm{N}$ 末端アミノ酸配列を解析した結果、可溶性 LOX-1 は LOX-1 分子の膜貫通領域のやや外側の $\mathrm{Arg}^{86}-\mathrm{Ser}^{87}$ 及び $\mathrm{Lys}^{89}-\mathrm{Ser}^{90}$ の間で切断され、可溶性分子となることが明らかとな った。【結論】酸化 LDL 受容体 LOX-1 は細胞表面に発現される のみならず、その一部が可溶性分子として細胞外に放出されるこ とが明らかとなった。生体内に存在する可溶性 LOX -1 がそのリカ ンドと受容体との結合を阻害する可能性、また、その血中濃度が 病態を反映しうる可能性などが示唆された。 
201 Progesteroneによる容量性 $\mathrm{Ca}^{2+}$ 流入の抑制

九州大学医学部心臟血管研究施設 分子細胞情報学部門 十島純子、平野勝也、西村淳二、金出英夫

【目的】 estrogenが内皮依存性血管弛緩反応を増強する報告は多い。 progesterone(PG)の内皮機能に及ぼす影響に関しては不明な点が多い。 内皮由来驰緩物質の産生は細胞質 $\mathrm{Ca}^{2+}$ 濃度 $\left(\left[\mathrm{Ca}^{2+}\right]_{\mathrm{i}}\right)$ によって制 御されており $\left[\mathrm{Ca}^{2+}\right]_{\mathrm{i}}$ の上昇には容量性 $\mathrm{Ca}^{2+}$ 流入が重要な役割を果 たすと考えられる。本研究では内皮細胞の容量性 $\mathrm{Ca}^{2+}$ 流入に及ぼす PGおよび17 $\beta$-estradiolの効果を明らかにする。【方法】fura-2負荷ブ 夕大動脈弁条片を用いて、表面蛍光測定法により内皮細胞の $\left[\mathrm{Ca}^{2+}\right]_{\mathrm{i}}$ を測定した。【結果】大動脈弁内皮細胞を1mM thapsigargin(TG)で 刺激すると、 $\left[\mathrm{Ca}^{2+}\right]_{\mathrm{i}}$ は急速に上昇後、持続的上昇を示した。この持 続的 $\left[\mathrm{Ca}^{2+}\right]_{\mathrm{i}}$ 上昇は細胞外に $\mathrm{Ca}^{2+}$ が無いと認められなかった。この $\left[\mathrm{Ca}^{2+}\right]_{\mathrm{i}}$ 上昇の持続相はPGによって濃度依存性 ( $\mathrm{IC}_{50}$ 值: $49.7 \mathrm{mM}$ ) に抑制された。PGの作用は1mMから認められ、100mM PGは投与 直前の $\left[\mathrm{Ca}^{2+}\right]_{\mathrm{i}}$ レベルを約 $26.7 \pm 5.0 \%$ まで低下させた。細胞外にCa ${ }^{2}$ が無い場合にTGが引き起こす一過性の $\left[\mathrm{Ca}^{2+}\right]_{\mathrm{i}}$ 上昇には、PGは影響 しなかった。一方、TGによる $\left[\mathrm{Ca}^{2+}\right]_{\mathrm{i}}$ 上昇の持続相に $17 \beta$-estradiolを 投与すると一過性に $\left[\mathrm{Ca}^{2+}\right]_{\mathrm{i}}$ は上昇し、引き続いてわずかに低下した。 Fura-2蛍光の $\mathrm{Mn}^{2+}$ quenchingによる $\mathrm{Ca}^{2+}$ 流入速度を測定したところ、 $\mathrm{TG} よ る\left[\mathrm{Ca}^{2+}\right]_{\mathrm{i}}$ 持続的上昇は $\mathrm{Ca}^{2+}$ 流入速度の促進として観察され た。PGはTGによるこの促進作用を抑制した【結論】PGは内皮細胞 における容量性 $\mathrm{Ca}^{2+}$ 流入を抑制することが明らかとなった。PGは 内皮由来驰緩物質の産生を抑制することが示唆される。

\section{2}

血清肝細胞增殖因子(HGF) と 糖尿病患者の網膜血管新生動態

東邦大学理学部生物分子科学 ${ }^{1}$, 同医学部付属佐倉病院臨床検査 医学 ${ }^{2}$, 同内科 ${ }^{3}$, 同眼科 ${ }^{4}$ 神吉昭子 ${ }^{1}$, 渡圐 促 $^{2}$, 村野武義 ${ }^{2}$,橋口 正一郎 ${ }^{3}$, ,塚光哉 ${ }^{3}$, 宮下 洋 ${ }^{3}$,八木文彦 ${ }^{4}$,竹内 忍 ${ }^{4}$, 白井厚治 ${ }^{2}$

【目的】肝細胞增殖因子(HGF)は血管内皮細胞の增殖作用、 血管新生作用を有し、血中でも検出されると報告されている。 血清中のHGFが糖尿病網膜症の血管新生動態で変動する可能 性を明らかにするために、1)培養系で、内皮細胞周期とHGF 分泌の関係、2)糖尿病患者における網膜血管新生動態と血清 HGF濃度の関係を検討した。

【方法】内皮細胞は上卜腈帯静脈内皮細胞(HUVEC)を用い、 增殖各段階のメディウム中のHGF謈度を測定した。糖尿病患 者は54名で、糖尿病網膜症は、網膜症を有さない糖尿病患者 (NDR)、単純糖尿病網膜症(SDR)、前增殖糖尿病網膜症 (PPDR)、增殖糖尿病網膜症(PDR)に分類した。PDRはレーザ 一治療前の症例とした。HGFの測定にはELISA法を用いた。

【結果】1)培養内皮細胞をホモジナイズした上清にHGFは認 められなかった。内皮細胞の培養メディウム中のHGFは、定 常期に比して增殖期に多く見られた。2)糖尿病網膜症別に血 清HGF值を見ると、NDR、SDR、PPDR間には有意な差は見 られなかった。非增殖性の糖尿病網膜症であるSDR、PPDR に比して、血管新生の認められたPDRで血清HGF值の高值傾 向が認められた。

【結論】HGFは内皮細胞增殖期に分泌され、糖尿病網膜症で は、網膜の血管内皮細胞增殖期に血中HGF高值の可能性が示 唆された。
203 サイクリン依存性キナーゼ阻害物質p21Waf-1を介した血管 平滑筋細胞の增殖と肥大の調節

久留米大学医学部病理学講座

岡本研一、加藤誠也、和田至弘、宮本哲哉、森松棇

（目的）血管賃害性の刺激は血管平滑笳細胞の過剩な增殖や肥大 を生し、動脈硬化性の合併症の原因となる。しかし、刺激に対応 して細胞が示す增殖と肥大への選択機転は明らかでない。今回、 我々は細胞周期の調節因子であるサイクリン依存性キナーゼ阻害 物質 $\mathrm{p} 21$ Waf-1の肥大機転への関与を検討した。

（方法）ラットの培盖平滑筋細胞を用い、PDGF及び Angiotensin II 刺激物質として、細胞增殖と肥大を各々 ${ }^{3} \mathrm{H}$-Thymidine、 ${ }^{3}$ H-Leucineの Up-takeで、細胞周期を Flow-cytometryで測定した。 p21Waf-1の発現は、Westem blottingで評価した。またAdenovirus vectorを用いたp21Waf-1の遺伝子導入を施行した。

(結果) PDGF $(10 \mathrm{ng} / \mathrm{ml})$ 刺激下では、 ${ }^{3} \mathrm{H}$-Thymidine、 ${ }^{3} \mathrm{H}$-Leucineの Up-takeは各 $481 \pm 64 \% 、 288 \pm 36 \%$ 增加し、增殖唖位に作用したが、 Angiotensin $\Pi\left(10^{-7} \mathrm{M}\right)$ は Insulin $10^{-8} \mathrm{M}$ の Pre-treatmentの条件下で各 $158 \pm 23 \% 、 426 \pm 54 \%$ と肥大優位に作用した。いずれの刺激物質 も単独で、細胞周期の G $1 / S$ 移行期に一一致して、一過性のp21Waf- 1 、 p27Kip-1の発現增加を示したが、InsulinのPre-treatmentは細胞增殖 作用が明らかでない濃度で、これらの発現を各2.6、1.6倍增加さ せた。更にp21Waf-1の遺伝子道入(500MOI)は、細胞增殖をControl

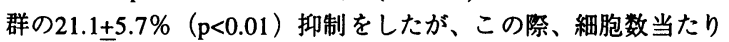
の蛋白合成は $140 \pm 17.5 \%(\mathrm{p}<0.01)$ とむしろ增加させた。

(結論) p 21 Waf-1による細胞周期の調節は、血管平滑筋紐胞の增 殖だけではなく、肥大形質の発現にも関与している可能性が示唆 された。

204 抗酸化率は、p21WAF1/CIP1を誘導し血管平滑筋細胞 の細胞周期を停止する。

東京大学 大学院医学系研究科加踰医学・老年病科阿古潤哉、吉 栖正雄、金承籍、江頭正人、橋本正良、飯島勝矢、梁一強、須藤紀 子、渡边德光、大池裕美子、秋下雅弘、鳥羽研二、大内尉義

【目的】抗酸化剂が、血管平滑筋細胞の細胞周期に与える影 響を検討した。【方法】ラット大動脈平滑筋細胞(RASMC)を 細胞密度を一定にして植元換え、24時間後に抗酸化郕である PDTC (py rrolidinedithiocarbamate)を培養液に添加した。細胞の DNA合成能を、 ${ }^{3} H$ H thymidineの細胞への取り込みにより、細 胞周期関連遗伝子発現を Northern blot法で解析した。【結果】 細胞密度が低い時 $\left(1 \times 10^{4} / \mathrm{cm}^{2}\right)$ は、既報のようにPDTC添加によ りRASMCに apoptosisを生じた。一方、細胞密度が高い時(5× $\left.10^{4} / \mathrm{cm}^{2}\right)$ は、PDTCの添加により、用量依存的に thymidineの取

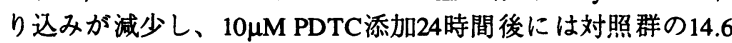
$\pm 0.5 \%$ に低下した。このPDTCによる細胞周期停止の経過中、 サイクリン(cyclin D1, cyclin A)のmRNAレベルの低下を認めな かったが、サイクリン・サイクリン依存性キナーゼのインヒ ビターである 21 WAF1/CIP1 mRNAレベルは、PDTC添加後8 時間て、9倍以上に上㫒した。PDTCによる細胞周期停止の可 逆性を検討するため、培盖液からPDTCを除去したところ、除 去後48時間で thymidineの取り込みはcontrolの75\%まで回復し た。【総括】抗酸化剤の添加で、血管平滑筋細胞の細胞周期 を可逆的に停止することが可能であった。抗酸化剂による細 胞周期の停止には $21 \mathrm{WAF} 1 / \mathrm{CIP} 1$ 鹪与している可能性があ る。 
205 p 21 Rasを介したシグナリングによる血管平滑筋細胞 アポトーシスの制御

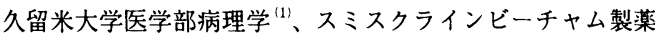
臨床薬理部門 2

宮本哲哉 (1)、加藤誠也 ${ }^{(1)} 、$ 森松稔 ${ }^{(1)} 、 J o n a t h a n$ C. Fox ${ }^{(2)}$

[目的]血管平滑筋細胞(VSMC)のアポトーシスは血管りモデリング や䋆状硬化の病変形成過程で認められる。我々はこれまでに dominant negative FGF受容体(DNFR)がMAP kinase(MAPK)の 活性化を介したFGFのシグナリングをblockすることでVSMCのア ポトーシスを誘導し、且つ他の增殖因子によるDNFR誘導性アポ トーシスの制御がRas伝達経路のマーカーであるMAPKの活性化に 関与することを示してきた。今回我々はRasの活性化そのものがア ポトーシスの制御に関わっているかどうかを検討した。

[方法] adenovirus vectorを用いた遺伝子導入法で種々の条件の下 constitutiveに活性化されたRas mutant(Ras[L61])とdominan negative Ras(Ras[N17])を各々VSMCに過剩発現させた後、 Western blotでMAPKの活性化を、定量的TUNEL法でapoptotic cellの数量を比較検討した。

[結果]Ras[L61]の発現はVSMCにおおけるMAPKの活性化を持続さ せ、DNFR誘導によるアポトーシスを抑制した(TUNEL陽性細胞

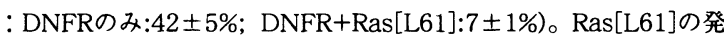
現によって細胞数は增加しなかった。一方Ras[N17]の発現は各増 殖因子によるMAPKの活性化をblockし、それ自身濃度依存性にア

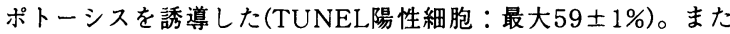
PDGFやEGFによるDNFR誘導性アポトーシスの抑制をblockした。 [結論]Rasの活性化はFGFのシグナリングによるVSMCのアポトー シス制御に必要且つ十分な要素である。

206 サイクリックAMP (CAMP) による血管平滑筋細胞 堌殖抑制：癌抑制遗伝子p53及びp21増加を介した細 胞周期停止とアポトーシス誘導

大阪大学第四内科 青木元邦、中村俊紀、森下竜一、林真 一郎、松下英腩、中神敬徳、谷山義明、守口篤、相垣実男、 荻原俊男

（目的）cAMPは重要なsecond messengerであり平滑筋細胞 の增殖に対する阻害作用が報告されているか、、その增殖抑制 作用の分子機構は不明である。本研究では、培美ヒ卜平滑筋 細胞を用いてCAMPの增殖及び細胞死に及ぼす作用を㭘討し た。(方法) PDGF增殖刺激下で、 phosphodiesterase type 3 に 対する特異的阻害䒩 (cilostazol) 及び cAMP analogue (forscolin、8-bromo-cAMP) 添加による細胞数変化、アポトー シス練胞数、DNA fragmentationについて検討した。また、 p53およびp21の蛋白量はウエスタンブロット法にて測定した。

(結果) PDGF增殖刺激に比して、cilostazol は細胞周期停止 を伴い、細胞增加を湌度依存的に有意に抑制した $(\mathrm{p}<0.01)$ 。 また、cilostazol、forscolinおよび8-bromo-cAMPはp53蛋白の発 現量を有意に增加させ $(\mathrm{P}<0.01)$ 、cilostazolはp21蛋白の発 現も濨度传存的に有意に增加させた（ $\mathrm{p}<0.01 ） 。 \mathrm{p} 53$ 及び p21遭伀子はアポトーシスを誘導することが知られているた め、cAMP增強によるアポトーシスを検討した。興味深いこ とに、cilostazolおよびforscolinは有意にアポトーシス細胞数及 ひDNAの断片化率を有意に增加させた $(\mathrm{P}<0.01)$ 。（結論） cAMPはがん抑制遗伝子p53および 21を介する細胞周期停止 及びアポトーシスを誘導し、ヒト平滑筋細胞增殖を直接抑制 する事が明らかになり、cAMP増強郕の動脈硬化病変治療へ の応用が示唆された。
207 オキシステロールによるOLET-Fラット血管平 滑笳細胞のアポトーシス誘導効果

東邦大学佐倉病院内科、同臨床検査医学 $*$

宮下洋、小山朝一、戸塚光哉、関東 渡邉仁、白井厚治*、 㫫岡玖夫

【目的】我々は、ヒト動脈硬化巣に存在するオキシステ ロールが血管平滑筋細胞にアポトーシスを誘導すること を報告し、硬化巣脆弱化の一要因と考えている。今回糖 尿病モデル動物であるOLET-Fラットの血管平滑筋細胞 を用い、オキシステロールに対するアポトーシス感受性 を検討した。【方法】細胞はLETO及びOLET-F血管平 滑筋細胞、オキシステロールは7-ketocholesterol (7keto)を用いた。アポトーシスはTUNEL法とDNA ladder で観察し、その定量は細胞剥離率とELISA法による断片 化DNAの測定で行った。【結果】7-keto添加により、 LETO及びOLET-Fの血管平滑筋細胞の核はTUNEL陽性 を示し、抽出DNAはladder patternを認めた。7-keto添 加後、細胞剥離率と断片化DNAは、7-ketoの蛑度依存 性および経時的に上界したが、その上界はOLET-F血管 平滑胼細胞でLETOに比し有意であった。【考察】糖尿 病状態の血管平滑筋細胞は、7-ketoによるアポトーシス 誘算作用に対する感受性が上界していることが示唆され た。

208 バルーンカテーテルによるラット頸動脈内膜肥厚に 対するニフェジピンの抑制効果

山形大学医学部臨床検査医学 ${ }^{1}$ 、同第 3 内科 ${ }^{2}$ 、同附属病院検査部 ${ }^{3}$

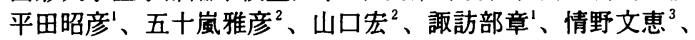
鈴木俊紀 $^{3}$ 、布施恒和 ${ }^{3} 、{\text { 加藤丈夫 }{ }^{2} \text { 、富永真琴 }}^{1}$

【目的】ニフェジピンの抗動脈硬化作用を、ラット紷顏動脈内膜 肥厚病変を用いて形態学的手法およびラット血管平滑筋細胞 (VSMC)での [ $\left.{ }^{3} \mathrm{H}\right]$-thymidine取り这みで检討した。【方法】約 $400 \mathrm{~g}$ の雄 S D ラットをコントロール群(C群)、ニフェジピン $0.3 \mathrm{mg} / \mathrm{kg} /$ 日投与群(LD群)、ニフェジピン $3 \mathrm{mg} / \mathrm{kg} /$ 日投与群( $(\mathrm{HD}$ 群) の3群(各群でn=9)に分け、ALZETの浸透圧ポンプを背部皮下に埋 め込み18日間持続皮下投与した。皮下投与4日目に、麻醉下に左 大腿動脈より Forgaty $2 \mathrm{Fr}$ のバルーンカテーテルを逆行性に左総頸 動脈(LCA)まで挿入し、バルーンを膨らませて同部を 3 回擦過し 内膜賃害モデルを作製した。内膜障害後15日目にLCAを摘出し、 $3 \mathrm{~mm}$ 間隔で 4 segment/匹に各々の組織標本を作製した。標本は Elastica-Masson(EM) と抗 $\alpha$-smooth muscle actin抗体(SMA)で染色し た。肥厚内膜面積/中膜面積 (I/M) 比は、顕微鏡画像処理装置 を用いてEM染色で内弾性板を境界として算定した。また、vitro の系としてVSMCの $\left[{ }^{3} \mathrm{H}\right]$-thymidine取り込み量を測定し細胞增

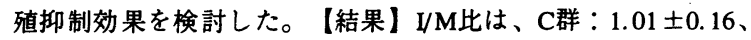

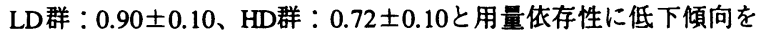
示し、特にHD群ではC群に比べ有意に低下した $(\mathrm{p}<0.05)$ 。内膜肥 厚病変部はSMA染色で强陽性を示しほほ全体が平滑筋細胞で占 められていた。また、2\%FBS刺激下のVSMCの $\left[{ }^{3} \mathrm{H}\right]$-thymidine 取り込み量は、ニフェジピン添加により瀑度依存性に低下した。 【結論】ニフェジピンは、VSMCの增殖抑制作用を有し、バルー ンカテーテル擦過によるラットの䅡動脈内膜肥厚病変部に対して も抑制作用があることが示唆された。 
209 血管平滑筋細胞の增殖とMatrix metalloproteinase-1(MMP-1) 発現に対するカルシウム拮抗薬(Diltiazem)の影㛙

久留米大学医学部病理学講座

和田至弘、加藤諴也、岡本研一、宮本哲哉、森松稳

（目的）カルシウム拮抗薬は、高血圧症や狭心症の治療薬として 広く使用され、L型カルシウムチャンネルに作用し血管収縮を抑 制するとされてきたが、プロテインキナーゼCを介した細胞增殖 抑制など、血管トーヌスの調節以外の作用も報告されている。ま た最近の大規模臨床研究では、本莧刜の投与で心血管事故の危険 度が増すとの報告もあり、本片の莱効を見直す必要性も論じられ ている。今回、我々は短時間作用型カルシウム拮抗菓(Diltiazem) の血管平滑筋細胞の增殖と間量を規定する因子である Tissue Collagenese(MMP-1)発現への影篦を検討した。（方法）ヒト大動 脈の培養平滑筋細胞を用いて、細胞増殖を細胞数計湘、 ${ }^{3} \mathrm{H}$-ThymidineのUp-takeで、蛋白合成を ${ }^{3} \mathrm{H}$-LeucineのUp-takeで測定 した。MMP-1の発現はWestem blottingをDensitometryで解析した。

(結果) Diltiazem単独では、細胞増殖への影䇾は明らかでなかっ た。ヒト平滑筋細胞では、PDGF(10ng/ml)の24時間刺激下で、細 胞数は 2.4 20.8 倍增加、同時にMMP-1の発現は、1.51倍增加し、 いずれもDiltiazem $\left(10^{-7}-10^{-5} \mathrm{M}\right)$ 添加により浱度依存性に抑制された。 ラットの平滑筋細胞でも PDGF $(10 \mathrm{ng} / \mathrm{ml})$ による ${ }^{3} \mathrm{H}$-Thymidineの Up-takeの増加は、Diltiazem添加により湌度依存性に抑制された。 またPDGFはLeucine Uptake も增加させたが、Ditliazem添加による 抑制効果は明らかでなかった。（䊅論）カルシウム拮抗莱は、血 管平滑筋細胞の增殖や間空分解醭素の発現を抑制するなど、血管 壁リモデリングに関与する可能性が示唆された。

210

ラット顐動脈のバルーン摖過におけるMT1-MMP発現の 経時的変化の検討

名古屋大学医学部老年科

神田茂、葛谷雅文、小池晃彦、井口昭久

【目的】動脈硬化進展過程において matrix metalloproteinase (MMP) 特に MMP-2 の重要な役割が指摘されてきた。近年 MMP-2 活性化の調節因子としてmembrane type MMP (MTMMP) が注目されている。私達は頝動脈擦過後の MT1-MMP の 蛋白レベルの発現ならびに免疫染色を利用したその局在を経時的 に観察した。【方法】体重約 $400 \mathrm{~g}$ の雄SDラットの左絵䅡動脈を バルンカテーテルで 3回擦過し、1、3、5、7、14日後、左総䅡動 脈を環流した後摘出し、外膜を除去した。これをhomogenizeし 上清を採取してタンパク渡度を各検体で均一にした後、抗 MT1MMP マウスモノクローナル抗体で immunoblotting を、また gelatin zymographyで MMP-2 の钲察を行った。さらに homogenizeする前の一部の組織を使って immunoblotting と同し 抗体で MT1-MMP の免度組織染色も行った。【結果】バルーン 摖過を行わない䫟動脈では MT1-MMP タンバクの発現を検出す ることはできないが、㨞過後 1 日には $66 \mathrm{kDa}$ 近傍及び $45 \mathrm{kDa}$ 近 傍に MT1-MMP の発現が認められるようになり $66 \mathrm{kDa}$ 近傍のバ ンドが主体であった。擦過後 5 日になると $45 \mathrm{kDa}$ 近傍のバンドが 主体となり、その後14日まで MT1-MMP の発現は持続していた。 また、活性化型 MMP-2 の比率は摖過後 5日から上昇した。さら に免疫組織染色でも肥厚した内膜内に MT1-MMP 陽性に染まる 平滑筋細胞が確認された。【結論】ラット頝動脈バルーン摖過に よる内膜肥厚は、MT1-MMP の発現を伴い、さらに MT1-MMP が擦過後経時的に prosessing をうけて約 $66 \mathrm{kDa}$ 加ら約 $45 \mathrm{kDa}$ なることか5 MMP-2 活性化に関与していることが示唆された。
211

ラット大動脈培養平滑筋細胞の増殖に伴う電位依存性及び 容量性 $\mathrm{Ca}^{2}+$ 流入機構の変化

九州大学医学部付属心管研究施設 分子細胞情報学部門 ${ }^{1}$ 、第 3 内科 ${ }^{2}$ 伊原栄吉 ${ }^{1}$ 平野勝也 $^{1}$ 西村淳二 $^{1}$ 名和田新 $^{2}$ 金出英夫 $^{1}$

【目的】分化した生体血管の平滑筋において電位依存性 $\mathrm{Ca}^{2+}$ 流入 は、細胞質 $\mathrm{Ca}$ 濃度 $\left(\left[\mathrm{Ca}^{2+}\right] \mathrm{i}\right)$ 上昇を引き起こし、収縮に関与する。 一方、容量性 $\mathrm{Ca}^{2+}$ 流入機構の生理的役割は明かでない。本研究で は、血管平滑筇細胞の增殖能変化に伴う電位依存性及び容量性 $\mathrm{Ca}^{2+}$ 流入機構の発現変化を明かにし細胞增殖におけるC $\mathrm{a}^{2+}$ 流入 の役割を検討する。【方法】ラット大動脈初代培養平滑筋細胞を 用いた。全細胞に対するBromodeoxyuridine(BrdU)取り込み細胞の 割合で增殖能を評価した。fura-2表面蛍光測光法により、 $100 \mathrm{mM}$ $\mathrm{K}^{+}$脱分極刺激及び30 $\mu \mathrm{M}$ Cyclopiazonic acid(CPA)による[C $\left.{ }^{2+}\right] \mathrm{i}$ 上 昇反応を記録し、それぞれ電位依存性及び容量性 $\mathrm{Ca}^{2}+$ 流入機構の 発現を機能的に評価した。 $\left[\mathrm{Ca}^{2+}\right] \mathrm{i}$ は、無刺激時を $0 \% 、 25 \mu \mathrm{M}$ Ionom ycin投与後の反応を $100 \%$ とした。【結果】10\%血清を含む 培地で培養した場合、平滑筋細胞は、7-8日でConfluentに達した。 $\mathrm{BrdU}$ 取り込みは、3日目を最大 $(52 \pm 6 \%)$ に、 $41 \pm 5 \%(5$ 日目)、20士 $8 \%$ (7日目)、9 $9 \pm 4 \%$ (Confluent)と培養日数とともに低下した。高 $\mathrm{K}^{+}$が引き起こす持続的な $\left[\mathrm{C} \mathrm{a}^{2+}\right] \mathrm{i}$ 上昇反応は、 $0.86 \pm 0.2 \%(5$ 日目)、 $3.9 \pm 0.5 \%$ (7日目)、 $3.9 \pm 0.5 \%(11$ 日目)と渐増し、培養日数とと もに電位依存性 $\mathrm{Ca}^{2+}$ 流入が增大した。一方、CPAによる $\left[\mathrm{Ca}^{2+}\right] \mathrm{i}$ 上昇反応は、約10分でPeakに達し、その後徐々に低下するため、

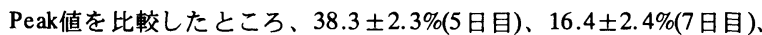
$15.9 \pm 1.2 \%$ (11日目)と渐隇し、培養日数とともに容量性 $\mathrm{Ca}^{2+}$ 流入 は低下した。【結論】ラット大動脈初代培養平滑筋細胞において 容量性 $\mathrm{Ca}^{2}+$ 流入機構の活性は増殖性と相関し、電位依存性 $\mathrm{Ca}^{2+}$ 流入は、増殖性の低下と細胞の成熟度に伴って增大した。容量性 $\mathrm{Ca}^{2+}$ 流入が平滑筋細胞の増殖に関与することが示唆された。

212 ヒト血管平滑筋細胞におけるチアソリジン誘算体による 血管内皮增殖因子 (VEGF) の産生作用

大阪市立大学第二内科、 ${ }^{*}$ 大阪市立絰合医凊センター内科

**大阪市立大学老年医学研究部門循聚器血管分野

山川律次郎、*細井雅之、小山英則、田中新二、福本まりこ、

神田博之、桧本正䓌、川岸隆彦、**奥野泰久、西沢良記、森井浩世

【背景】閒塞性趿脈硬化症、心筋梗塞に対する血管内皮增殖因子 (VEGF) による血管新生寮法が、注目されている。我々は上卜大 䖝脈血管平清能細胞 (HSMC)において、チアソリジン誘導体がVEGF 産生に及ぼす影管を検封した。

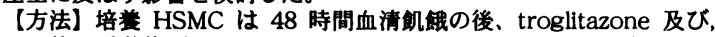
その他の誘望体 (ploglitazone, LY 171883, Wy-14653, 8(S)HETE, bezafibrate) を添加した後, medium 中の VEGF 灣度を ELISA 法 を用い测定した。また Northern blotting 法にて VEGF mRNA レ ベルを㭲㣥した。また蛣尿病患者において troglitazone $400 \mathrm{mg} /$ day 内服 3 ヶ月後の血中 VEGF流度も検讨した。

[结果] troglitazone $10 \mu \mathrm{M}$ 添加後，6，12，24，48 時間の VEGF 算度は $64 \pm 6.9,115 \pm 8.8,205 \pm 8.0,322 \pm 18 \mathrm{pg} / \mathrm{ml}$ 之時間㑈存性 に上昇した。また troglitazone $0-25 \mu \mathrm{M}$ 添加により 24 時間後の

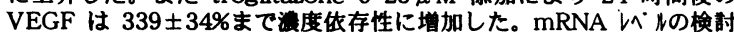
でも同様であった。他の PPAR rアゴニスト (ploglitazone, LY 171883)でも VEGF 産生增加作用が認められたが、PPAR $\alpha$ アゴニ スト (8(S)HETE, Wy-14653, bezafibrate) では影萸がなかった。 また HSMC において PPAR $\gamma$ の造伝子発現を RT-PCR 法により碗 现した。彭尿病患者 28 名の検封では、troglitazone 内服前の血中 VEGF 瀄度は $84.2 \pm 62.2 \mathrm{pg} / \mathrm{ml}$ であったのに対し 3 ヶ月後は 91.0 $\pm 75.9 \mathrm{pg} / \mathrm{ml}$ と有意な变化を示さなかった.

【結語】血管平消紡細胞におけて、チアソリジン誘道体が PPAR r を介して VEGF の産生を六進することが示された。この作用は血管 局所で生じる可能性がある。 
213 エンドセリンA/B非選択的受容体捛抗薬TAK044による内 皮特異的增殖因子VEGF産生促進作用

大阪大学加柃医学 西牧弘行、福尾恵介、須原敏充、荻原俊男

（目的）バルーン障害血管における新生内膜肥厚の抑制には血 管平滑筋練胞の増殖抑制とともに内皮再生が重要である。我々は 本学会においてエンドセリンA/B非選択的受容体拮抗薬TAK044 がバルーン障害後の内皮再生を促進することを報告したが、今回 この機序を明らかにする目的でAK044が内皮特異的增殖因子 VEGFの産生にどのような影響を及ぼすかを検討した。（方法） ラットをTAK044投与群とcontrol群に分け、(1)血管断面におけ るIntima/Media比を比較検討した。(2)Evans blueを用い内皮再 生を評価した。(3)障害後新生内膜におけるETA/ETB receptor、 Vesicular Endothelial Growth Factor(VEGF) 、内因性ET-1の 発現を免疫組織学的に比較検討した。(4)摘出血管からのVEGFの 分泌をELSA法にて測定した。（5)培養平滑筋にTAK044を刺激し 24hのVEGFmRNAの発現をcontrolと比較した。（結果）バルー ン障害後血管断面のI/M比は有意に減少した。Evans blue評価に よる内皮再生は有意に促進した。障害後新生内膜において ETA/ETB receptor, VEGF, ET-1の発現はTAK044投与群におい て増強した。障害血管からのVEGFの分泌はTAK044投与群にお いて增強した(ELISA法)。培養平滑筋にTAK044を刺激すると24h 後のVEGFmRNA発現はcontrolよりも増強していた(Northern Blot 法)。（結論）TAK044は障害後新生内膜において内因性 ET-1の発現を増強し、新生内膜に発現しているETAもしくはETB receptorに作動し、その結果内皮特異的なVEGFが分泌され内皮 再生を促進する結果、バルーン障害後新生内膜肥厚が抑制された 可能性がある。

\section{4}

C-reactive protein (CRP)による血管平滑笳細胞遊走抑制作用

名古屋大学大学院医学研究科発育・加齢医学講座老年医学

内藤通孝、野村秀樹、加藤由利子、井口昭久

【目的】CRPは急性相反応蛋白のうちの主要なものの一つで、その 作用には炎症促進作用と抗炎症作用の二面性が指摘されている か、その病態生理学的意義については不明な点が多い。一方、CRP は粥状硬化病変に早期より沈着していることが最近明らかにされ ており、慢性炎症としての側面を有する粥状硬化の発生、進展に おいてもCRPが何らかの役割を演じている可能性が示唆される. 本研究では、血管平滑筋細胞（SMC）の遊走に対するCRPの作用 を検討した。【方法】SMCは牛胎児胸部大動脈中膜より explant法 により継代培養した。SMCの遊走はBoyden chamber 法によって定 量した. 走化因子としては fibrinogen $(300 \mu \mathrm{g} / \mathrm{ml})$ とPDGF-BB (50 $\mathrm{ng} / \mathrm{ml})$ を用いた。【結果】ヒト recombinant CRP $(\sim 200 \mu \mathrm{g} / \mathrm{ml})$ は fibrinogen およびPDGF-BBによるSMCの遊走を濃度依存性に抑制 した。CRP自身にはSMCに対する走化活性はなかった。

【結論】CRPは一方では、補体活性化などの炎症促進作用が知られ ているか、今回の結果は、CRPが平滑筋細胞の遊走を抑制すること によって、他方では抗炎症性に働く可能性があることを示してい る. CRPが動脈壁においてその炎症性機序に影響することにより、 㢷状硬化の発生・進展に関与している可能性が示唆される.
215

ヒト大動脈平滑笳細胞における酸化L $D L$ 受容体CD36 の意義

大阪大学大学院分子制御内科学 松本健吾、平野賢一、野 崎秀一、西田誠、中川裕美子、大屋健、Mohamed Janabi、 船橋徹、山下静也、松澤佑次

[目的]我々はCD36欠損マクロファージ $(M \phi)$ を用いて酸化い し受容体としてCD36が重要な役割を果たすこと、ヒト大動 脈動脈硬化巣ではCD36を強く発現する泡沫化M $\phi$ とスカべ ンジャー受容体クラスA(SRA)を発現するM 違があることを報告した。一方、粥状硬化巣には平滑筋細 胞(SMC)由来の泡沫細胞も存在することがいわれているが、 詳細は明かではない。我々はヒト大動脈由来SMC(HASMC) にCD36が発現していることを発見し、今回その意義につい て検討した。[方法1CD36の発現はRT-PCRを用いて検討した。 免疫染色(HASMC、ヒ卜大動脈凍結切片)及ひ 法はOKM5(anti-CD36 antibody)、抗ヒト $\alpha$-smooth musde actin を用いた。細胞内脂質蓄積はHeider法及びOilPedO染色にて 検討した。[結果]1)5人から得られた平滑筋細胞にCD36mR NAの発現を認め、FACS及び免疫組織学検討にてCD36蛋白 の発現を確認した。2)CD36(+)œ11は1251-OXDLと特異的結 合を示し、泡沫細胞となることを確認した。特異的結合及 ひ細胞内脂質蓄積はOKMSにて有意に抑制された。CD36(-)c ell゙はOXDLによる泡沫化は認められなかった。3)CD36(+)

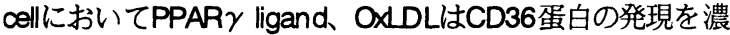
度依存性に有意に増加させた。4) ヒト大動脈動脈硬化巣にC D36/a-smooth muscle actin陽性泡沫細胞を認めた。[結論]HA SMCの泡沫化にはCD36が関与していることが示され た。

\section{6 培養血管平滑筋細胞による一酸化窒素の産生 -SHR とWKYの比較一}

和歌山県立医科大学循環器内科 湴田昌範 坊岡進一 佐谷 修 浦 雅子 羽野卓三 西尾一郎

【目的】我々はこれまで内皮障害モデルを用いた灌流実 験で、高血圧自然発症ラット(SHR)ではWistar Kyoto rat (WKY)に比し内皮依存性の血管拡張が障害されており、 また培䔄内皮細胞からのnitrogen oxide(NOx)合成が SHRで有意に低值である結果を示してきた。今回は培養 血管平滑筋のNO産生に差があるか否かを比較した。

【方法】SHR-SP, SHR-SRならびにWKY(いずれも14週 雄 $i z m) よ り$ 培養血管平滑筋細胞を作成した。NO合成刺 激として、interleukin-1 $\beta$ (IL-1 $\beta, 0 \sim 2 \mathrm{ng} / \mathrm{ml})$ 及び lipopolysaccharide(LPS, $0 \sim 100 \mu \mathrm{g} / \mathrm{ml})$ を用い 24時間培養後、培養液中のNOxをGriess法で測定した。 またWestern blottingでNOSの発現を測定した。

【結果】IL-1 $\beta 2 \mathrm{ng} / \mathrm{m} \mid$ 刺激によるNOx合成はSHR-SP; $114 \pm 10$, SHR-SR; $187 \pm 22$, WKY; $368 \pm 52 \mu \mathrm{M} / \mathrm{mg}$ protein, $(n=4)$ でWKYで有意に高値であった。LPS $100 \mu$ $\mathrm{g} / \mathrm{m} \mid \mathrm{W}_{1}$ 激ではSHR-SP; $726 \pm 57$, SHR-SR; $653 \pm 99$, WKY; $545 \pm 89 \mu \mathrm{M} / \mathrm{mg}$ protein, $(n=4)$ と3群間に有意差 を認めなかった。Western blottingも上記の結果を支持 する結果であった。【結論】SHR-SR, SHR-SPでは WKYに比しIL-1 $\beta$ receptorを介したNOx合成が障害さ れている可能性が考えられる。 
217 単球・マクロファージにおけるレニン・アンジオテンシン系 の血管壁血栓形成に及ぼす影整

福岛県立医科大学医学部第一内科

永田兼司、石橋敏幸 中里和彦、清野義㐬、丸山幸夫

帝京大学医学部内科寺本民生

【目的】急性冠動脈症候群におけるプラーク破綻にマクロファー シは重要な役割を担い、プラーク破綻に際しての血栓形成にマク ロファージの関与が示唆されている。我々は昨年の本学会冬季大 会でヒト単球・マクロファージにおけるレニン・アンジオテンシ ン系(RAS)の存在を明らかにした。そこで今回、マクロファージに おける RAS の役割を明らかにするために血管壁血栓形成との関連 に着目し、単球・マクロファージの組織因子(TF)、プラスミノゲ ンアクチベーターインヒビター(PAI-1)産生能とそれに及ぼすア ンジオテンシン変换醭素(ACE)阻害薬、アンジオテンシン II type1 受容体(AT1)拮抗薬の影箱を検討した。

【方法】健常人末梢血より比重遗心法、プラスチック付着法で単 球を分離した。同種 lipoproteln deficient serum(LPDS) $2 \mathrm{mg} / \mathrm{ml}$ および酸化 $\mathrm{LDL} 100 \mu \mathrm{g} / \mathrm{ml}$ 存在下で $1 \times 10^{5}$ 個 $/ \mathrm{ml}$ の灌度で培養 した。培素系にアンジオテンシン II(AngII)、ACE 阻害薬、AT1 拮 抗薬を添加し、培養上清中の $\mathrm{TF}$ および PAI-1 濃度を ELISA 法で 経時的に測定した。

【結果】AngII $\left(10^{-8} \mathrm{M}\right)$ 添加により TF、PAI-1 の産生能が有意に上 昇した。ACE 阻害薬 $\left(10^{-9} \sim 10^{-8} \mathrm{M}\right)$ の添加によって漕度依存性に培 義上清中の TF、PAI-1 濃度は低下した。また、AT1 拮抗薬(10${ }^{10} \sim 10^{-8} \mathrm{M}$ )の添加によっても TF、PAI-1 浱度は低下した。

【総括】単球・マクロファージの RAS は TF、PAI-1 の産生能に 関与し、ACE 阻害薬、AT1 拮抗薬による単球・マクロファージ RAS の阻害は血管壁血栓形成の予防に有効である可能性が示唆さ れた。

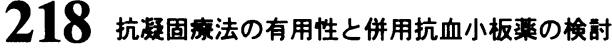

佐賀医科大学内科

大森答造、高息敏伸、江村 正

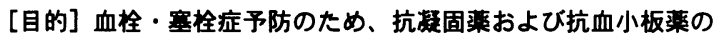
投与が広く行われているか、投与の基隼はそれほど明確でない。 それらをいかなる病態に用いると有用であるかを知ることを目的 として、まずワーファリン投与の実態と有用性を検村した。 [方法] 対象は佐賀医科大学付属病院にて、ワーファリンを投与 された154症例である。内訳は、心浯并膜疾患15例、并是換術後 72例、急性心筋梗塞12例、陳旧性心荕梗塞15例、狭心症 3 例、

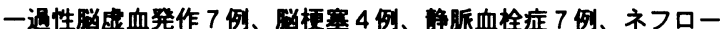
せ症候群10例、その他の疾患 9 例である。各疾患別に、ワーファ リンの投与量と期间、併用した抗血小板菜、血栓・塞栓症および 出血性副作用の発生について検証した。

[結果］ワーファリンの投与吾は $2 \sim 6 \mathrm{mg}$ で平均 $2.9 \mathrm{mg}$ 、投与 期间は平均32ケ月であった。心㶓井膜疾患ではアスピリン併用か 2 例、ジピリタモール併用か 5 例あり、併用なしの 1 例で下血か みられた。弁雷換術後ではアスピリン併用か 9 例、チクロピジン 併用か 3 例、ジピリタモール併用か50例あり、ジピリタモール 併用例で血栓弁、䁖塞栓が各 1 例みられた。急性心筋梗塞では、 チクロピジン併用か 3 例、ジピリタモール併用が 1 例あり、血栓 . 塞栓、副作用ともにみられなかった。棟旧性心筋梗塞では、アス ピリン、ジピリタモール併用の 1 例で心篆梗塞再発がみられた。 一過性媨虚血発作では、アスピリン併用が 2 例、チクロピジン併 用が 4 例、篮梗塞、出血性副作用ともにみられなかった。

[結諭] ワーファリンによる抗准固素法を行った154症例のうち、 血栓・塞栓の発生が 4 例、出血性の副作用が 4 例みられたが、 致死性のものはなく、比較的安全な治淩法と考えられた。
219

Bins wanger 脳症における血小板凝集・凝固系の検討

名古屋第一赤十字病院 神経内科

渡辺正樹、浜田健介、岡田洋平、真野和夫、渡邉英夫

【目的】Binswanger 脳症の病態に血小板凝集や疑固系がいかに 関与するかを検討した。

【対象】Binswanger 脳症（B群） 47例（M/F=26/21; 平均年齡 $70.4 \pm 7.1$ 歳） ラクナ脳梗塞（L群） 150 例（同 $93 / 57 ； 68.6 \pm 7.9$ 歳）。両群とも慢性期例。

【方法】顠動脈超音波検査（B-mode 法）にてプラークスコア (PS)、内膜中膜複合体（IMT）を、MR angiography（TOF 法） にて狭窄スコア（SS）を求め、頭顠部の大血管病変の程度を評 価した。しかる後に $\beta$-thromboglobulin（ $\beta$ TG；ng/ml）、 thrombin-antithrombin IIIcomplex（TAT; $\mathrm{ng} / \mathrm{ml} ）$ 、von Will ebrand 因子活性（vWF；\%）を測定し、而群で比較した。 【結果】1）PS、IMT、SS は両群で差がなかった。2）B群/L 群て $\beta$ TG ; 43.1 $\pm 29.0 / 33.7 \pm 25.2 、 \mathrm{TAT} ; 4.1 \pm 3.0 / 3.2 \pm 3.4$ 、 vWF；186.8 $448.0 / 157.4 \pm 44.9$ といずれもB群の方が高値であ った。

【結論】B群において血小板凝集や凝固系は六進していた。これ はvWFの上昇すなわち動脈硬化（内皮細胞損傷）の進行を認め、 頭频部の大血管狭窄性病変の程度はL群と差を認めないことから、 頭頸部以外の全身動脈硬化あるいは大脳白質を中心とする小動脈 病変に起因すると考えられた。従って抗血小板療法や抗凝固療法 を行うことで、全身状態あるいは大脳白質病変の増悪を予防し得 るといえた。

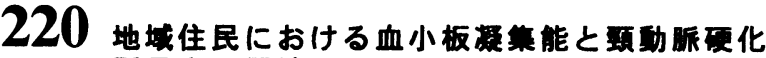
所見との閶連

大阪府立成人扁センター1) 筑波大学社会医学系 ${ }^{2)}$

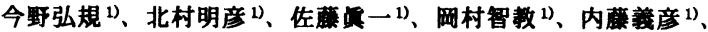

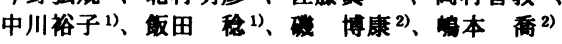

【目的】血小板始集能が心觔梗塞や脳梗塞の危険因子である可 能性が指畝されているが、血小板准集能と動腺硬化所見との 関連は明らかでない。本研究では地域住民を対象として、血 小板准集能と頚趿脈硬化所見の関連について検封を試みた。 【方法】対象者は秋田県 I町およひ茨城県 $\mathrm{K}$ 町の住民検診をを 受診した $50 \sim 74$ 歳の男性 391 人である。ただし、そのうち 抗血小板郕を服薬している等の理由から27人を集計から除外 した。血小板凝集能は、 4 灌度の ADPを用いて、比法法によ り血小板准集能閶值係数(PATI; 血小板が不可逆的疑集を惹起 すると考えられる ADPの最低湌度)を求め指標とした。頡䵢 脈硬化の進展度は、超音波検査により、被䁌者の左右それぞ れの総頚動係および分岐部から内頡動豚にかけてのIMTMAX を求め、指標とした。あわせて、血圧、総コレステロー ル、HDLーコレステロール、随時血桾の测定および問診によ る契煙習慣の確認を行った。

【結果】PATIはほほ対数正規分布を示した。ロジスティック 回㷌分析により年軨、血圧值、総コレステロール、随時血糖、 HDLーコレステロール、契煌習頃を調整したところ、血小板 凝集能と到勳脈硬化所見の有無との間に有意な関連は認めら れなかった。この㑯向は、降圧郕服用者 88 人を除いた解析に おいても同様の倾向であった。

【結論】血圧值を始めとした従来の循蕀器疾患発症危倹因子 が、到動脈硬化所見と関連していたのに対し、血小板准集能 之頚動脈硬化所見との関連は認められず、血小板准集能の充 進は動脈硬化の進展に関与するよりも血栓形成に関与する可 能性が示された。 


\section{1} アデノシンの血小板凝集抑制作用に対する急性運動の协果

東京医科歯科大学第三内科澤田三紀、岸 幸夫、粕谷奈都子、 辰巳政弘、先田信哉、渡辺智幸、足利贵志、粕谷健司、沼野藤夫

【目的】アデノシンは虚血に対する防御機構のメデイエーターとし て知られている。最近アデノシン $\mathrm{A}_{2 \mathrm{a}}$ 受容体欠損マウスにおいて 血小板凝集能の克進が認められたことから、血小板に対する内因 性アデノシンの役割が注目される。我々はこれまで、NO、プロ スタサイクリン等の内因性抗血小板物質に対する血小板感受性に ついて運動の急性および僈性効果を追求してきた。今回、アデノ シンの血小板凝集抑制効果に対する急性運動の影響とその機序に


してBruce 法により、トレッドミル負荷試酫を施行、その前後で 採血し、直ちに多血小板血 デノシン $2.5 \mu \mathrm{M}$ 存在下および非存在下で $0.1-10 \mu \mathrm{g} / \mathrm{ml}$ のコラー グンを刺激物質として血小板凝集能を吸光度法で測定、用量反応 曲線を作製した。それぞれの $\mathrm{EC}_{50}$ 值を求め、その比 $\mathrm{R}$ をアデノシ ン感受性の指標とした。また、安静時採血したPRPに対して運動 後の血中䈨度に近似した $0.5 \mathrm{ng} / \mathrm{ml}$ エピネフリン存在下で stirring 負荷 (1000 回転、12 分間)を加えたのち同様な検討を行 った。【結果】(1) 被験者全員 Bruce StageIII-IVに到達し(平均負 荷時間 10 分 37 秒)、虚血性変化その他の異常所見を認めなかった。 (2) 負荷後、血小板凝集能の用量反応曲線は㹩度左方にシフトし、 $\mathrm{R}$ 値の有意な低下が認められた(負荷前 $2.13 \pm 0.11$ 、負荷後 1.68 $\pm 0.09 ; \mathrm{P}<0.001)$ 。(3) stirring、エピネフリン前処置した血小 板のアデノシン感受性は减弱した。【結論】運動負荷により、アデ ノシンの血小板凝集抑制効果は堿弱した。その機序として運動負 荷に伴う機械的ストレスやカテコラミンの分泌增加が考えられた。

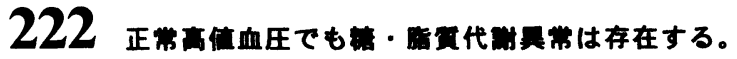

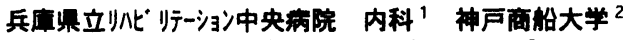

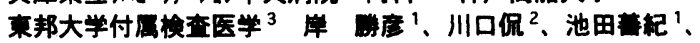

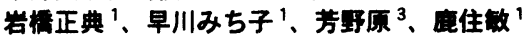

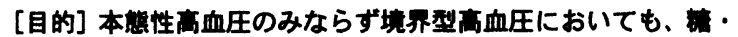
墌代代罢常の存在することが知られている。今回、正常血圧の

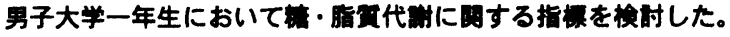
[方法] 对尖は男子大学一年生 198 名（98\%は 18 才、BM I $21.6 \pm 3.6$ [S D ] k g/m ${ }^{2}$ ) 。一夜䋓食後、坐位血压、体目と

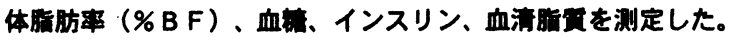

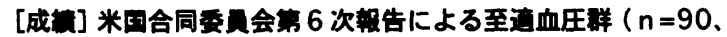
OP) と比聥すると、正常高值群 $(n=46, H N)$ ではB M I (23.1 \pm 4.8 [S D] V S $\left.20.4 \pm 2.2 \mathrm{~K} \mathrm{~g} / \mathrm{m}^{2}\right)$.\% B F $(20.9 \pm 7.7$ VS $16.3 \pm 4.2 \%)$ TG $(69 \pm 32$ VS $55 \pm 21 \mathrm{mg} / \mathrm{d}$ I) 。 RLPーコレステロール (C) $(4.3 \pm 0.7 \vee S 4.0 \pm 0.7 \mathrm{mg} /$ d l ) とTG/HDL - C (1.29 $0.75 \vee S 0.98 \pm 0.45)$ は 禹かったか、Lp（a)、LDLとHDLコレステロール（C） は 2 群问で童はなかった。さらにHNの空晒時血耤 $(91 \pm 7$ V $\mathrm{s} 88 \pm 8 \mathrm{mg} / \mathrm{d}$ l) 、インスリン $(9.5 \pm 5.2 \vee \mathrm{s} 7.1 \pm 2.0$

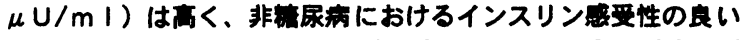

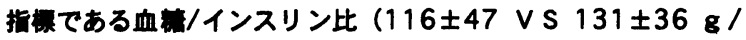
U）は低かった。正常血圧群 $(n=52)$ ではOPとHNの中仙の 结果であり、禹血圧詳 $(n=10)$ のB I $(26.5 \pm 6.5 \mathrm{~kg} / \mathrm{m}$ 2) 、\%BF $(25.6 \pm 8.8 \%) 、 T G(96 \pm 84 \mathrm{mg} / \mathrm{d} \mathrm{I}) 、 R$ L P - C $(5.8 \pm 4.0 \mathrm{mg} / \mathrm{d} \mathrm{I})$ 、インスリン $(11.4 \pm 4.9 \mu$ $\mathrm{U} / \mathrm{m}$ I) はHNよりさらに禹く、血满/インスリン比はさらに低

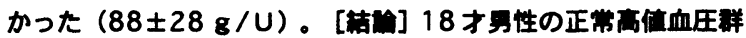

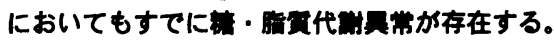

\section{3 高血圧性動脈病変の成因について}

群馬大学医学部保健学科病理 日本抗体研究所*

鈴木慶二 福田利夫 *中嶋克行

[目的］高血圧性動脈病変の成り立ちについて高血圧ラッ卜を用い光顕

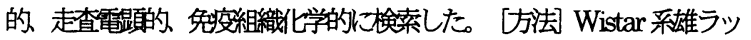

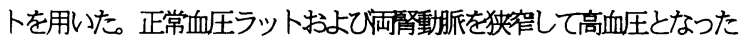
術後 1〜6週のラット腸間膜動脈の凍結切片、パラフィン切片を作製し、

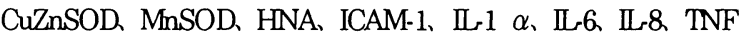
$\alpha$ の免窪染色を行なつた。更に $0.2 \% \mathrm{NBT}$ 溶液を屠殺前に静注し活性 酸素と反応したホルマザンを観察した。また、屠殺前へパリン生食、グ ルタールアルデヒトで潅流定後パラフィン切片を作製し、病変部、非 病変部をパラフィンプロックより切りだして走査電影て観察した。[結 果 走查電顕的に高血圧ラットにおいて非病変部の内皮緗包に配列の不 規則化や変性像が見られ、病変部には著明な白血球力内皮細胞一の付着、 内皮䌈砲の変性、脱落力淮察された NBT 静注高血圧ラットにおいて、 肉眼的に病変部は青色か著明となつていたが 非病変部は弱 ) 青色を示 した。光顕的に類線維素変性を示した病変部では自血球や内皮細胞にホ ルマザンか観察され、非病変部内皮細胞にもホルマザンが少みられた。 HNA は病変部にのみ観察された。CuZnSOD.MnSOD の発現は正 常血圧ラットの内皮細胞においては軽微であったが 高血圧ラットの非

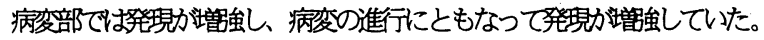
正常血圧ラットにおいて内皮細胞にICAM-1、I-1 $\alpha$ 、 IL-6、 IL-8. TNF $\alpha$ の発現がごく軽度であったが 高血圧ラットの病変部および非病変部 においてICAM-1、I-1 $\alpha 、$ I-6、I-8. TNF $\alpha$ 強く発現していた。

[結論] 高血圧病変の成り立ちに接着因子やサイトカインの発現増強 活性酸素の産生か関与すると考えられた。

\section{4 傏尿病大血管障害（MA）の現況について}

1) 第二岡本総合病院糖尿病科，2 滋賀医大第三内科 紀田康雄 ${ }^{1}$, , 原田夏樹 ${ }^{1}$, 柏木厚典 ${ }^{2)}$, 吉川隆一 ${ }^{2}$ )

【目的と方法】一定の基準で血栓性脳梗塞 ( $\mathrm{CI}$ ), 虚血性心疾患 （IHD），下肢閉塞性動哌硬化症（ASO）の 3 つのMAの有無を判 定できた 2 型煻尿病 842 例（男508例，女334例， $58 \pm 12$ 歳, 煻尿 病歴 $8 \pm 8$ 年 ) を対象として, 各々の頻度, 相互関係, 臨床像, 危 険因子，予後を調べた。CIはCTまたはMRIによる画像診断で， IHDは心電図所見から，ASOは既に報告してきたfoot examination により判定した。

【結果】IHDは285例（34\%），CIは269例（32\%）, ASOは88例 (10\%) 飞認めた。422例（50\%）がいずれかを合併し，40例（5 \%) は全てのMAを合併していた。特にASOを有する88例のうち 63例がIHDを，54例がCIを合併し，ASOは全身の動脈硬化の進展 を示唆する所見と考えられた。多変量解析では， 3 種類の MA の 全てに共通の危険因子として加龄, 裾尿病歴, 高血圧, HDL-C 低下が重要であった。てれらに加えIHDには総CHOが, ASOには 喫煙が重要であった。合併するMAの数と自律神経機能, 腎症の 程度も密接汇関係し, MAが多いほど予後も悪がった。約 4 年間 の観察期間での死亡率はMAを合併しなかった群に比べると全て のMAを合併していた群では約20倍高く，心血管障害による死亡 が多かった。

【結論】 2 型糖尿病患者の半数は何らかのMAを合併しており， MAを多く有する例ほど予後も悪かった。いずれのMAも自覚症状 亿現れない無症候の例す多く, 細小血管障害を合垪する例や榶尿 病歴の長い例は下肢の診察や非侵襲的検查を用いた積極的な MA の評価が重要である。また, 血糖コントロールと同時に他の危険 因子の制御むMAの進展予防のため重要と考えられた。 
225

2型糖尿病患者におけるC Tを用いた腹部大動脈石灰化率と 危険因子、合併症との関係

清水市立病院内科 ${ }^{1)}$ 慶應義塾大学医学部内科 ${ }^{2}$ 中検 ${ }^{3)}$ 老年科 ${ }^{4)}$ 国立循環器病センター内科 5) 武井直之1) 2) 武井泉 ${ }^{2}$ 3) 山内 晃 $^{1)}$ 江口豊寿 ${ }^{1)}$ 広瀬信義 ${ }^{3}$ 都島基夫 ${ }^{4)}$ 渡辺清明 ${ }^{3)}$ 猿田享男 ${ }^{2)}$ 【目的】動脈硬化度を非侵襲的、定量的に測定する方法として腹 部大動脈のC T検索の応用がなされ、動脈硬化性血管障害の発症と 腹部大動脈石灰化との関連が指摘されている。2型糖尿病患者におい てもMacroangiopathyの進展抑制は長期予後を決定する因子として重 要である。そこで今回我々は2型糖尿病患者において腹部 C Tを施行 し腹部大動脈硬化度と危険因子、また合併症との関連を男女別に検 討した。【方法】対象は2型糖尿病患者男性90例、女性70例(各々

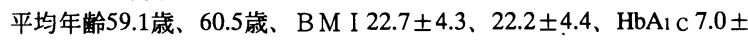
1.3、7.2 $\pm 1.2 \%$ ）。C Tによる腹部大動脈断面全体に対する壁内石 灰沈着部面積を石灰化率として計算した。対象を男女の 2 群に分け、 各々石灰化率と各種パラメーターや高血圧、喫煙、Macroangiopathy 既往、Microangiopathy合併の有無との関連を検討した。

【结果】 1 男女間で年齢、F P G、BM I、HbA 1 c に有意差はな かった。石灰化率は男性で高い傾向を認めた。2 男性の石灰化率は 年齢と正の相関を認め $(\mathrm{r}=0.22 \mathrm{p}<0.05)$ 、罪病期間長期化と血中 $\mathrm{HD} \mathrm{L}$ - C 低下に伴い高値傾向を認めた。Microangiopathy合併群は 石灰化率が有意に高かった $(\mathrm{p}<0.05)$ 。3 女性では、年齢と正の 相関を $(r=0.38 \quad p<0.05)$ 、血中HD L - C と負の相関を $(r=-0.25$ $\mathrm{p}<0.05)$ 認め、血中TG上昇に伴い高值傾向を認めた。高血圧合 併群、Macroangiopathy既往群は石灰化率が有意に高かった（それぞ れ $\mathrm{p}<0.01$ と $<0.05)$ 。

【苦到】2糖㽷病患者において腹部大動脈石灰化率は男性で高い 傾向を認めた。男性で加齢、女性で加齢、HD L - C 低值は腹部大 動脈石灰化進展に関与する可能性が示唆された。女性で Macroangiopathy既往群は腹部大動脈石灰化率が有意に高かった。

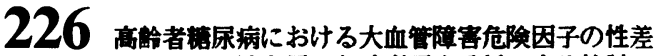
一H P L C 法を用いたりホホ蛋白分析による模㣙一

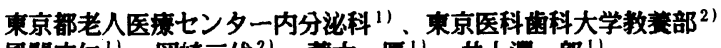

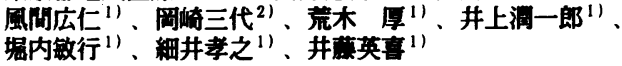

【目的】高榆者嫆尿病における大血管障害危険因子の性差を、

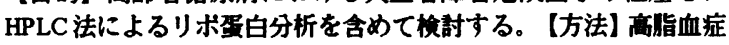

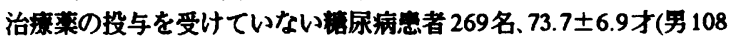

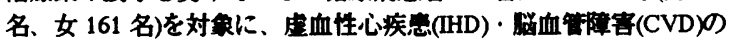

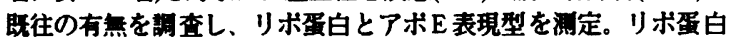
分析にはHPLC 法を用い各りホ榲白分西のコレステロール(C)、ト リクリセライド(TG)含量を定量した。LDL·HDLについては粒子 サイスにより1，m、nに亜分画しC含量をガウス近似法で求めた。 【結果】1)HD・CVDの再急軍に性とアボE 表現形による差を琶め ず。2)女性 IHD 急者の LDL-m-C、LDL-1-C、LDL-s -C、LDL-TG、 HbAlc およひ収綟期血圧は有意または有意俱向で高值、HDL-m-C は有意に低值。3)男性 IHD 急者の HDL-s -C と HDL-m-Cはともに 低值、年解、㹡张期血圧は高值。4)女性 CVD 急者の LDL-m-Cは、 有意に高值、HDL-m-C は低值相向であった。5)男性 CVD 意者の

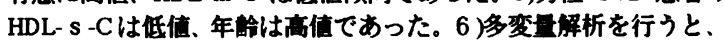
IHD では女性で LDL-m-C、HDL-m-C、HbAlc、叹絾期血圧が、男 性で抬張期血圧が有意な独立した䦌遥因子であり、CVD では女性

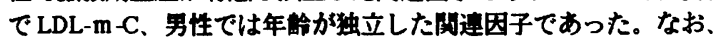

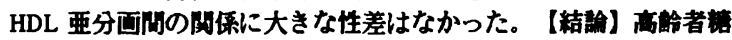

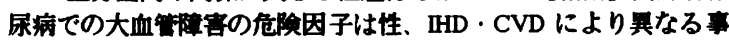
か明らかとなった。特に、男性では HDL- $\mathrm{s}-\mathrm{C}$ 低值、女性では HDL-

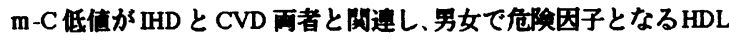
柆子サイスが翼なるという知見を得た。女性では、LDL-m-CがIHD だけでなく CVDとも間連することか明らかとなった。
227 血糖コントロールと䅡動脈内中膜䙡合体肥厚病変の進展 -KUMAMOTO STUDY 10年後における横断調査から一 熊本大学代謝内科 笹原誉之, 堺政和, 松田浩史, 阿南敬親, 竹村 亨,松村剛, 枇杷剛, 西川武史, 和気仲庸, 岸川秀樹, 七里元亮

【目的】我々はKUMAMOTO STUDY(KS)にてインスリン頻回 注射㙩法(MIT)の筷格な血糖コントロールにより細小血管合併症 の進展が抑えられることを示した. また、頝動脈の内中膜複合体 肥厚(Intima-Media Thickness; IMT)の增加が糖尿病患者で報告 された．今回、血栯コントロールの大血管合併症への影㸷を検鿾 するため、KS 10年後の患者でMTを測定し、横断調查の結果か らMITの意義を検封した. 【方法】 KSに登錄 10年後のNIDDM 患者(CIT(従来注射寮法)群 25名, MIT群 23名, 性・年鈴を Match)を対象に，高解像度超音波断層装罯を用い、描出された IMTを測定した.【成續】 HbA1cはCIT群で $8.8 \pm 0.8 \%$, MIT群で $7.2 \pm 1.0 \%$ MIT样で有意に低值であった。この際の大血管合併 症のイベント発生率はCIT群：MIT群で1.8: 0.9(/100患者・年) であった. 最大IMTはCIT群で $2.05 \pm 1.18 \mathrm{~mm}, \mathrm{MIT}$ 群で $1.35 \pm$ $0.55 \mathrm{~mm}$ でMIT群で有意 $(\mathrm{p}<0.01)$ に低值であった. 平均IMTも同 様の結果であった.【結論】KS対象患者は研究開始時無作為に 割り付けており、両群で研究開始時にIMTの有意差は無かったと 推定され、今回の両群における差は10年間におけるIMT進展の差 と考えられた。MITにより預動脈病変の進行がCITよりも抑えら れる事が示唆され、笅格な血糖コントロールの大血管合併症に対 する有用性が示された。

\section{8 各種 $\beta$ 遮断薬のインスリン抵抗性に及ぼす影雾}

国立循瑟器病センター 動脈硬化代謝部門

木村祐子、長谷川雅昭、小松良哉、鈴木正昭、洪秀樹、

西大条靖子、都岛基夫、原納優

【目的】 $\beta$ 遮断薬はインスリン抵抗性を増大させ、その程度 は $\beta 1$ 選択性薬が非選択性薬に比べて柽度であり、 $\beta 2$ 刺激性 のある $\beta 1$ 選択性菜はインスリン抵抗性を改善するとの報告も ある。その機序として $\beta 2$ 受容体を介する末梢血流增加の関与 が示唆されるが明礁でない。今回我々は各種 $\beta$ 遮断薬のイン

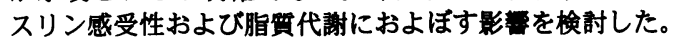

【方法】本態性高血圧患者に、 $\beta 1$ 非選択性で ISA のあるボ ピンドロール(囚サンドノーム, $\mathrm{n}=14) 、 \beta 1$ 非選択性で ISA の ない弱いカリウムチャンネル開口作用のあるチリソロール(® セレカル $\mathrm{n}=7) 、 \beta 1$ 選択性で ISA と $\beta 2$ 刺激性のあるセリプ ロロール（®セレクトール， $\mathrm{n}=9$ ) 、 $\beta 1$ 選択性で ISA のないメ トプロロール(®ロプレソール n=4)をそれぞれ 2-4 カ月内服投 与し、投与前後のインスリン感受性 (SSPG 法) ,75gOGTT, 血 中脂質を比較した。【結果】1.血圧は各種 $\beta$ 遮断藥で低下した。 2.SSPG 值はチリソロールで低下し（前 $212 \pm 48$, 後 $166 \pm 40$ $\mathrm{mg} / \mathrm{dl}$, mean $\pm \mathrm{SE}, \mathrm{P}<0.05)$ 、ボピンドロールとセリプロロ ールで変化せず、メトプロロールで悪化㑯向を認めた。3. 75gOGTT におけるフドウ榶面掼、インスリン面㮴は有意に変 化を認めず、血中総コレステロール値、中性脂肪値は有意に 変化を認めなかった。【総括】インスリン感受性はチリソロ ールで改善し、ボピンドロール、セリプロロールて変化せず、 メトプロロールで悪化攧向を認めた。 $\beta$ 遮断薬の種類によっ てインスリン感受性に及ほすす影算は異った。 
229

血清肝細胞増殖因子(HGF)濃度と動脈硬化の指標(大動脈 Pulse Wave Velocity :PWV)の高血圧患者における相関 大阪大学医学部加噛医学

松本圭子 守口篤 森下竜一 駒井則夫 檜垣実男 荻原俊男

<目的> 肝細胞增殖因子（HGF）は、強力な内皮增殖作用と内皮 保護作用を有する。更に内皮細胞において AngII と TGF-b が局所 の HGF の産生を減少させることも報告してきた。一方、血清 HGF 濃度は高血圧の合併症と相関し、診断の指標となることも明らかに した。本研究では、封筒法にて本態性高血圧患者を対象に ACE 阻 害薬(シラザプリル)と遮断薬(アテノロール)を 6 ヶ月間投与し前後 で比較検討を行った。また血清 H G F 濃度を測定し、血圧臓器障害 との関連について検討すると共に Pulse Wave Velocity (PWV)を指 標とした動脈硬化との関連についても検討した。

<方法>ACE 阻害薬(シラザプリル;1.0〜2.0 mg/日)と遮断薬(アテ ノロール;50 100mg/日)を本態性高血圧患者(男性 9 人, 女性 6 人)に 6 ヶ月投与した。その前後で動脈硬化(PWV;FCP-4731 Fukuda Denshi) と血清H G F 濃度を醉素免疫学的测定法(EIA)にて測定し、 その相関を検討した。糖尿病、肝緊心肺疾患のあるものは除外した。 <結果 >収縮期血圧及び払張期血圧は両群共同等に有意な下降を 認めた(p<0.01)。大動脈 PWV はシラザプリル投与群で有意な改善 を認めた $(\mathrm{p}<0.05)$ 。血清 HGF 濃度ではシラザプリル投与群で有意な 減少がみられた(p<0.05)。

〈考察〉シラザプリル投与群では高血圧で増加した血清 HGF 濃度 の低下と大動脈 PWV の改善がみられた。以上より大動脈 PWV と 血清 HGF 濃度は動脈硬化進展とともに增加することより、動脈硬 化の指標となりうると考えられた。

230

ブドウ糖経口負荷後の血清遊離脂肪酸濃度の変動からみた インスリン抵抗性の臨床的評価について

国立循環器病センター 内科動脈硬化代謝部門

洪 秀樹, 都島基夫, 大原せつ, 木村祐子, 長谷川雅昭, 小松良哉, 鈴木正昭, 西大條靖子, 原納 優

目的 : ブドウ糖経口負荷後の遊離脂肪酸 (NEFA) の変動から、イ ンスリン抵抗性の臨床的な評価を試みる。

方法 : 69 歳以下の入院症例 112 例を対象とした。BMI 25 以上を obese、それより下をleanとした。肝、堅機能障害合併例、およ び経口剂、インスリン使用例は対象から除外した。入院後、2012 $\mathrm{kcal} / \mathrm{d}, \mathrm{CHO} 299 \mathrm{~g}$ の標準食を $3 \sim 4$ 日間投与後、早朝空腹時に $75 \mathrm{gOGTT}$ を実施、fasting, $30,60,90,120,180 \mathrm{~min}$ に静脈採血、血 糖 (Glucose)、血清IRI, NEFA 濃度を測定した。75gOGTT の結 果は、ADA 基準（1997）により判定した。

結果 : 対象はlean 50 例 (平均BMI : 21.8)、obese 62 例 (平均BMI : 29.6）に分類され, さらにlean Normal (N) 11 例, lean IGT 13例, lean DM 26 例, obese N 13 例, obese IGT 25例, obese DM 24 例, に細分された。IRI 反応は lean DM $<$ lean $\mathrm{N}<$ obese $\mathrm{DM}<$ obese $\mathrm{N}<$ lean IGT< obese IGTの順に六進していた。また、fasting IRI と fasting NEFA とは正に相関した $(r=0.237, n=109, p=0.0133)$ 。 一方、OGTT後の NEFA の変動を見ると、N群やIGT 群では、糖 負荷後 $30 \mathrm{~min}$ においてNEFAは明らかに抑制されたか、 lean DMお よびobese DMでは、その抑制はみられなかった。そこで、 (NEFA (fasting) - NEFA (30min)\} と $\Sigma$ dGlucose との関係をみると、 $\mathrm{r}=$ $-0.395, n=109, p<0.0001$ と有意の負の相関をみとめたため、lean と obeseについても各々検討したところ、 leanでは $\mathrm{r}=-0.491, \mathrm{n}=$ $48, p=0.0004$ 、obese ではr $=-0.299, n=61, p=0.0191$, と各々、有 意な負の相関をみとめた。

結論：糖負荷後 30min において血清 NEFA 濃度が抑制されるか否 かは、インスリン抵抗性の臨床的指標として有用と考えられる。
231 インスリン抵抗性における高血圧発症機序ーエイコサペンタ エン酸(EPA)が $\mathrm{Na}^{+} / \mathrm{H}^{+}$exchanger活性に与える影響一 兵庫医科大学第一内科正井美帆、藤岡由夫、奥村隆啓、 森本真史、藤原正義、三好 彩、鈴木 洋、岩崎忠昭 自衛隊阪神病院内科”細合浩司

【目的】我々は食塩感受性を有する高血圧境界型ラット(BHR) において、高インスリン血症、高中性脂肪血症で $\mathrm{Na}^{+} / \mathrm{H}^{+}$ exchanger(NHE)活性立進を認め、昇圧することを確認してい る。今回、脂質代謝改善、血圧降下作用を有するEPA(Ethyl icosapentate)を投与し、NHE活性の変動を検討した。【方法】 8 週齢雄性BHRに60\%フルクトース食を負荷し(F)、4週後に2 群に分けF-E(-)群(EPA非投与)、F-E(+)群(EPA $1000 \mathrm{mg}$ $/ \mathrm{kg} / \mathrm{day} 、 4$ 週間投与)とした。その間、血圧の変動を観察、16 週齢に採血し、血糖、血中インスリン值(IRI)、血清コレステ ロール(TC)、血清中性脂肪(TG)を測定した。血小板を分離し、 既存の方法により細胞内 $\mathrm{Na}^{+} 、 \mathrm{Ca}^{2+} \mathrm{pH}$ とプロピオン酸 $\mathrm{Na}$ よる細胞内酸性化条件において Vmaxを測定し、NHE活性の指 標とした。また、標準食を与えたBHR(C)においても同様の検 討を行った(C-E(-)群、C-E(+)群)。【結果】IRIはFで有意に高 値であった。血圧は $\mathrm{C} 、 \mathrm{~F}$ ともにEPA投与で有意に低下した。 TGはEPA投与で低下したが、EPAは血糖、IRIに影響を与えな かった。細胞内 $\mathrm{Na}^{+}$は差が無く、細胞内 $\mathrm{Ca}^{2+}$ はF-E(+)群では F-E(-)群に比べ有意に低值であったが、C-E(+)群とC-E(-)群に 差はなかった。細胞内 $\mathrm{pH}$ はEPAによる影響はみられず、また VmaxはFにおいてEPA投与で低下する傾向を認めるものの有 意差は認めなかった。【結語】高インスリン血症における NHE活性光進に対し、EPAの有する血圧降下作用が与える影 響は少ないと考えられた。

232 血糖コントロールによる 2 型糖尿病患者の過酸化脂質お よび可溶性接着分子の変動

清水市立病院内科 ${ }^{1)}$ 慶應義塾大学医学部内科 ${ }^{2}$

山内 晃1) 武井直之 ${ }^{1,2)}$ 江口豊寿 ${ }^{1)}$ 猿田熟男 ${ }^{2)}$

【目的】糖尿病患者の大血管障害進展抑制は，長期予後を決定す る因子として重要である。近年糖尿病性大血管障害の進展と血清 可溶性接着分子の関連が指摘されている。今回我々は, NDDM 患者の入院治療前後で可溶性接着分子 (ICAM-1, VCAM-1) お よびその発現に関与すると考えられている過酸化脂質(LPO)濃度 を測定し，血糖コントロールによる可溶性接着分子およびPOの 変動について検討した.

【方法】対象は、NIDDM患者9例（男性6例、女性3例、年齢58.3 歳、BM26.1 $\pm 5.2, \mathrm{HbA}_{1} \mathrm{c} 10.4 \pm 2.9 \%$ )。体重 (BMI) , FPG, 空腹時脂質 (TC, TG, HDL-C)，LPOおよび血清ICAM-1, VCAM-1を入院治療前後で測定し，比較検討した。

【結果】 1 入院治療により, BMI $(26.1 \rightarrow 25.0, \mathrm{p}<0.01)$, FPG $(200 \rightarrow 141 \mathrm{mg} / \mathrm{dl}, \mathrm{p}<0.05), \mathrm{TC}(219 \rightarrow 189 \mathrm{mg} / \mathrm{dl}, \mathrm{p}<0.01)$ は有 意に低下したが, TG, HDL-Cは, 有意な変動を認めなかった。 2 LPOは, 血糖コントローにより, 低下傾向を認めた。(3.8 $\rightarrow 3.4 \mathrm{nMol} / \mathrm{ml}, \mathrm{p}<0.1$ )

3 ICAM-1は血糖コントロールにより，有意に低下した（257 $\rightarrow$ $222 \mathrm{ng} / \mathrm{ml}, \mathrm{p}<0.05)$ が, VCAM-1は血糖コントロール前後で有意 な変動を認めなかった。

4 VCAM-1の低下率は, 血糖改善率, TC低下率およひLPOの低 下率のいずれとも関連を認めなかった。

【結論】 2 型糖尿病患者において, 血糖コントロールにより, 大 血管障害進展の危険因子である過酸化脂質および血清可溶性接着 分子ICAM-1の濃度は低下した。過酸化脂質とICAM-1 との関連は 不明であった。 
233 糖尿病性大血管障害発症進展におけるミトコンドリア由 来 free radical の意義

熊本大学医学部代謝内科 西川武志、七里元亮

Albert Einstein College of Medicine Brownlee, M.

【目的】糖尿病患者において free radical の增加が認められるこ とは以前より示されており、糖尿病性大血管障害の機序の一つと して注目されているが、 free radical増加の機序にはまだ不明の 点が多い。今回我々は、ミトコンドリア由来 free radicalが高糖 濃度培養下の内皮細胞において增加しているか否かについて検討 した。【方法】human smooth muscle cells(HSMC)およびbovine aortic endothelial cells(BAEC)を $5 \mathrm{mM} よ ひ ゙ 30 \mathrm{mM} \mathrm{glu-}$ cose 下で 1-7 日間培養。fluorescent probe C2938を用いた flowcytometory 法、およびTBARS 法により細胞内 $\mathrm{H}_{2} \mathrm{O}_{2}$ およ び過酸化脂質を定量、同様の実験を酸化的リン酸化抑制剤である thenoyltrifluoroacetonson(TTFA), carbonyl cyanide mchlorophenylhydrazone(CCCP)存在下でも行った。また、ミト コンドリア由来 free radical と intracellular AGE との関連につ いても検討した。【結果】 $30 \mathrm{mM}$ glucose 24 時間の培養にて $\mathrm{BAEC}$ 内 $\mathrm{H}_{2} \mathrm{O}_{2}$ の有為な増加が $(100 \pm 1.39$ vs. $157.19 \pm 1.91$ $, \mathrm{p}<0.001) 、 7$ 日間の培盖にてBAEC内過酸化脂質の有為な増加

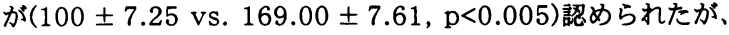
HSMC では認められなかった。また、この増加はTTFA および CCCPの投与により完全に抑制された。同様に $30 \mathrm{mM}$ glucose 7 日間の培養にて BAEC 内 AGEの増加が(1.15 \pm 0.10 vs. $2.01 \pm$ $0.15, p<0.01)$ 認められ、TTFAおよびCCCPの投与により抑制 された。【結論】高糖濃度培養下の内皮細胞においてミトコンド リア由来 free radical が増加し、また、この free radicalにより intracellular AGE も増加している事が示され、ミトコンドリア 由来 free radical と糖尿病性大血管障害の関与が示唆された。

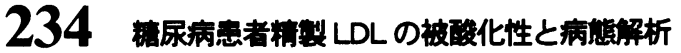

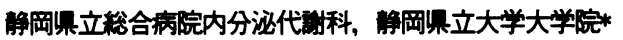

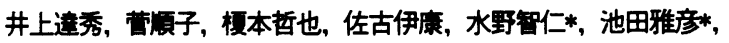
宣田多量子*


られることが報告され, in vitro しLL 化が glucose の存在でえ 進することが示されている.しかしこれまでの研究では粗裂され たしL を用いての研究が少ないため本研究では、急者血策より LL 画分を精製し， $\mathrm{Cu}^{2+}$-酸化時の diene の生成， ApoB 断片化 について睤べ，血筷ビタミンC (VC), $\alpha$-トコフェロール $(\alpha-T o c)$

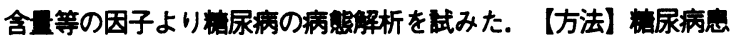
者 (NIDOM)より早朝空凌時に採血し，不速統密度勾眍超息心法 を 2 回行いしLL画分を得，透析した. LD 画分を $5 \mu \mathrm{M} \mathrm{Cu}{ }^{2+}$ 存 在下酸化し diene の生成, ADOB断片化を梌期した.【結果] LL 画分は ADOB 蛋白のみを含有することを SDS-PAGE で礁配した. 急者の平均年数，BMI，HoA1C (\%)はそれぞれ 64，22，9.7であ った. lag time は ADoB断片化時问 (t 1/2), VC, $\alpha$-Toc と高度 の相関を示し, $t 1 / 2$ は血然 TBARS, $\alpha$-Toc と有意な相関を示

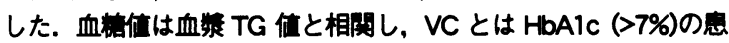
者でのみ負の相閶を示した．また合併症を伴う急者では，伴わな

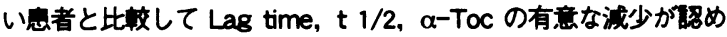

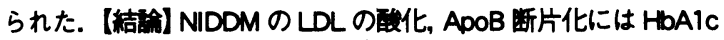
よりも $\alpha-T o c, V C$ 娍少か強く関与していると考えられる.
235 NIDDM患者の血糖コントロールと赤血球のSOD 様活性, ピタミン Eとの関連

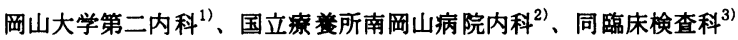
久山文子 ${ }^{1)}$ 、三島康男 ${ }^{21}$ 、木烟正義 ${ }^{22}$ 、安藤充 ${ }^{3)}$ 、竹山雅美 ${ }^{3)}$

【目的】赤血球のSOD様活性は抗酸化活性を反映しているが ESR法で測定しうる。赤血球のSOD様活性は, 高血糖状怒で グリケーションを受け活性が低下する。この様な活性低下は 糖尿病や老化に関与しているといわれている。

今回, 我々はNIDDM患者において赤血球のSOD様活性と抗 酸化物糞としてビタミンE（以下vitE）との関連について検 討した。【方法】NIDDM患者 100 名(平均年齢 57 歳, 男性 67 名, 女性 33 名, 平均 $\mathrm{HbA} 1 \mathrm{c} 7.6 \%$ ) と健常人 43 名（平均年龄 43 歳, 男性 20 名, 女性23名）について赤血球中の蛋白量当た りのSOD様活性をESR法を用いて測定し，vitEを觉光法で測 定した。また, 高脂血症の影製を除くためvitE/TC（総コレ ステロール）で検討した。【成繶】健常人をC群，NIDDM患 者をDM群として検邿したところvitE/TCに有意差は認めら れなかったが, 赤血球のSOD様活性はDM群で有意に低下し ていた。 $(\mathrm{P}=0.0002)$ また, DM群のうち HbA1c8.0\%末满の 患者を $\mathrm{Dl}$ 群， $8.0 \%$ 以上の患者を $\mathrm{Dh}$ 群として検討したところ， C 群, DI 群では赤血球のSOD様活性とvitE/TCに相関は認め られなかったが Dh群では強い正の相関を認めた。 $(\mathrm{p}=0.002)$ 【考察および結語】糖尿病患者では健常人にくら ベ, 赤血球のSOD様活性は有意に低下していた。糖尿病のコ ントロール不良な例では健常例, 軽症例とくらべSOD様活性 とvitE/TCの協调関係が顕著であった。これによりコントロー ル不良例でvitEの補充の意義が示唆された。

\section{6}

培養ヒト単核球における Advanced Glycation End Products (AGE) によるCD36 遭伝子の発現

1)旭川医科大学 臨床薬理、2)佐野病院 内科、

3) 川崎医科大学榶尿病内科

岩島保法1)、2)、岡田瑞穂2)、衛籐雅昭3)、佐野博昭2)

【目的】脂肪細胞分化において中心的役割を担う核内受容体である Peroxisome proliferator-activated receptor $\gamma($ PPAR $r$ ) は. その発現から脂肪、エネルギー代謝のみならず、炎症、兔疫、血管 リモデリング、大腸癌等、種々の病態に広く関与すると想定されて いる。最近、PPAR $r$ のリガンドである Thiazolidinedione や15deoxy prostaglandin J2 は、マママロファージ (M申)活性化の negative regulator であり、炎症性サイトカインを初めとした種々 の遭伝子発現を抑制するにもかかわらず単核球の分化を促進し、酸 化 LDL 受容体とされる CD36 の遗伝子発現を誘導することが報告 された。一方、CD36 の promoter はPPAR $r$ 蛋白複合体の直接の 槚的であること、ヒ卜動脈硬化䉾におけるM申由来の泡沫細胞に AGE やPPAR $\curlyvee$ が集積していること、AGE は Granulocyte/ Macrophage Colony Stimulating Factor の発現を介してM $\phi$ の 增殖を促進し、M 細胞膜上の AGE 受容体と反応することによ り、種々の遗伝子発現に影敀を与えることが報告されている。そこ で、培養ヒト単核球を用いて、AGEによるCD36の遗伝子発現に ついて検討した。【方法】(1) 細胞培養: 健常七ト末梢血から、 Ficoll-Paque (Pharmacia) により単核球を得た。(2) RT-PCR による CD36 および Scavenger receptor A (SR-A) の寈伝子発 現：ヒト単核球を、 $100 \mu \mathrm{g} / \mathrm{ml}$ の AGE-BSA あるいは $10 \mu \mathrm{M} の$ Troglitazone (T) を含有する $10 \%$ FBS 加 RPMI 1640 で 24 時 間および 6 日間培養したものから、AGPC 法により Total RNA を 抽出し、CDNAを合成した。【結果】(1)AGEおよびTは, plate に付着した単核球を增大させた。(2) RT-PCR の結果、AGE およ びTは、 6 日間培養したヒト単核球において CD36 mRNA 発現を 誘迸したか、SR-A mRNA の発現は認められなかった。24 時間の 培養では、いずれの発現も認めなかった。【結論】培養ヒ卜単核球 において、AGEは細胞の增大とともにCD36 mRNA の発現を誘導 した。PPAR $r$ をしたCD36 発現增大による酸化 LDL 取り込みの 增加は、M申の泡沫化をさらに促進し、棦状動脈硬化症の進展に関 与している可能性が示唆された。 
237 肥满女性を対象とした隇量プログラムにおけるレプチンと $\beta$ 3 アト・レ゙リ受容体遺伝子変異との関連

東京大学医学系研究科健康增進科学 李 廷秀、川久保清

東京大学医学部検查部 橋本佳明

【目的】肥満度とレプチンの関連が検討されているが、 $\beta 3$ アドレリリ $(\beta 3 \mathrm{AR})$ 受容体変異との関連でみた検討は少ない。本研究では、地域 で行なわれた減量プログラム前後のレ゚チ変化と $\beta 3$ AR 遺伝子変異 型との関連をみることを目的とした。

【方法】12 週間の減量プログ 弘を完了した女性 23 人 (平均年齢 48.2 歳)を対象とした。減量プログうムは運動指導と個別の栄養指導とした。 $7^{\circ}$ 口 $\eta^{*}$ 前前後に血液検查、体組成、体力検查をおこない、 $\beta 3$ AR 受容 体遺伝子変異別(正常、へテロ、杔)に変化を検討した。

【結果】指導前後で、体重は $2.6 \mathrm{~kg}$ 減量し、BMI は 26.9 から 25.8 に減少した。1 日歩数は 4221 歩增加し、搷取工祃ギ 量は $360 \mathrm{kcal}$ 減 少した。 $\beta 3$ AR 遺伝子正常型は 12 人、変異へテ听 10 人、变異杔が 1 人であった。指導前のBMI とレプチ莀度の間には、有意な正の相関が あった $\left(\mathrm{R}^{2}=0.48\right)$ が、 $\beta 3 \mathrm{AR}$ 遺伝子正常型における相関が高かった。 $\beta 3$ AR 遺伝子変異別には、BMI、レプチには有意差はなかった。指導 後の体重変化量には遺伝子変異別に差がなかったが、ウ工仆师毞は 正常型の群で減少した。血液検査値の変化量には差がなかった。体


の相関は主に $\beta 3 A R$ 遺伝子正常型によるものであった。

【結論】減量プログう前には、BMI とレフチ濃度には有意な正の相関 があったが、この関倸は $\beta 3 A R$ 遺伝子変異正常型に強かった。減量7 听 弘は、遺伝子変異によらず有効であったが、体重変化量とに゚゙ 変化量の正の相関は主に遺伝子変異正常型によるものであった。

238 高血圧患者における体脂肪分布と血中レプチンおよび PAI-1活性の開保について

杏林大学医学部 高齢医学

大荷満生、蒔田隆二、柳田 幸、山村尚子、水川真二郎、

中島久実子、秦 臀哉

(目的)脂肪細胞は、単にエネルギーをトリグリセライドとして 蓄えるだけではなく、レプチンなどの様々な液性因子を産生、分 泌する。これらの液性因子は、摄食行動やエネルギ一消費、桾・ 脂質代謝、インスリン作用などに影管を与え、動脈硬化に深く関 係している。この研究では、高血圧患者を対象に、体脂肪分布と レプチンおよびPAI-1活性の関係を検討した。

(対象および方法)糖尿病をもたない高血圧患者53例(男性22例、 女性 31 例、平均年橉 $65 \pm 10$ 嵅)を対象にした。早朝空腹時に採血 し、血清脂質、アポ蛋白、インスリン、レプチン、PAI-1活性を測 定した。同時に腹部CT検查をおこない、臍レベルでの内臓脂肪面 積 $(\mathrm{V})$ と皮下脂肪面積 $(\mathrm{S})$ を測定し、V/S比を算出した。

(結果)(1)血中レプチン濃度はBMI と有意の正相関を示した $(\mathrm{r}=0.633 、 \mathrm{p}<0.001)$ 。しかし、血中レプチン濃度は内䑏脂肪面積 やV/S比と有意な関係を示さなかった。(2)PAI-1活性は、BMIが大 きくなるにしたがい上昇する傾向がみられたが有意の関係ではな かった。しかし、PAI-1活性は、内䑏脂肪面積ならびにV/S比とい ずれも有意の正相関を示した $(\mathrm{r}=0.724 、 \mathrm{p}<0.001 、 \mathrm{r}=0.509$ 、 $\mathrm{p}<0.01$ )。

(考案)レプチンとPAI-1は、同じ脂肪細胞から分泌される夜性因 子でありながら、レプチンは体脂肪量と、PAI-1活性は内㖪脂肪量 に関係すると考えられた。
239 老年入院患者の予後からみた血清コレステロール値(第 2 報)

宮崎愛和病院 内科・成人病研究室、同栄盖科*、同検査科**、 同苗科***、滋賀医大第 1 内科****

齊藤 昇、八田文裕子、櫻井英雄、長友英博、齊藤三郎、中島一郎、 村田 比、安永孝高、内野勝子*、中山清児 ${ }^{* *}$ 、神谷美紀 ${ }^{* *}$ 、

須田牧夫***、佐山晴美 ${ }^{* * * *}$

【目的】臨床経過における血清コレステロール值の変動から、患者 の予後を推定しうるかどうかを調べた。

【方法】死亡した 51 例につき、死亡前 1 力月以内、 $2 \sim 4$ 力月、 5 〜10 カ月と 11〜20 カ月における血清コレステロールなどの臨床検 查値を調べた。死亡例の栄養補給状態によって群別した。病院食摂 取の 8 例（男性 6 例、女性 2 例）、経管栄養の流動食 23 例（11 例、 12 例）、静脈栄養 9 例 (4 例、 5 例) と中心静脈栄養 11 例（5 例、 6 例）であった。対照の退院出来た 16 例（2 例、14例）はすべて病 院食摂取であった。これら症例につき、早朝空腹時に採血し、生化 学検査を行った。

【結果】死亡例は死亡前 1 カ月以内に血清コレステロール、HDLC、TP と Alb が減少傾向だが、静脈栄養例と中心静脈栄養例ではこ れらとへモグロビン $(\mathrm{Hb})$ は有意に減少していた。䜩下障害から病 院食以外の方法で栄盖摄取している例で、死亡前のこれらの值の減 少が著明であった。病院食摂取例の死亡は病状の急変の場合もあり、 有意な変化ではなかった。死亡前 $11 \sim 20$ カ月に比較して、死亡前 1 カ月以内では血清コレステロールは病院食例で $22 \%$ 、経管栄養で $28 \%$ 、静脈栄養で $46 \%$ 、中心静脈で $48 \%$ の減少、退院例では $6 \%$ の減少であった。この時血清 Alb は $20 \% 、 30 \% 、 37 \%$ と $44 \%$ の減 少、退院例で $1 \%$ の増加であった。

【結論】死亡前 1 カ月以内では血清コレステロール、HDL-C、TP とAlb が減少する傾向で、病院食摂取不可能例て減少していた。

\section{0 血清脂質に対する食事内容の自己規制効果の検証}

国立病院九州医療センター内科、九州大学第二内科*

江藤仁香、上野道雄、冨永光裕、宮城めぐみ、

土橋卓也*、中村義人*、後藤健一*、佐内 透

【目的】血清脂質に対する食事内容の自己規制効果を検 証する。【方法】福岡国税局の成人男子職員 860 名 (平 均年齢 $30 \pm 6$ 歳) を対象に、1984年から1997年までに毎 年血液検査と食事規制に関する調查を行った。

【結果】13年間の追跡期間中に脂質摄取をまったく自己 規制していない群 $(\mathrm{A}$ 群) 、時々規制している群 $(\mathrm{B}$ 群) では、血清コレステロールはA群：19.5 $21.6 \mathrm{mg} / \mathrm{dl} 、 \mathrm{~B}$

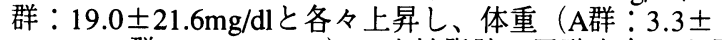
$4.3 \mathrm{~kg} 、 \mathrm{~B}$ 群: $3.2 \pm 4.4 \mathrm{~kg}$ )、中性脂肪、尿酸も各々上昇 した。脂質摂取を毎年規制している群 (C群) では、期 間中の血清コレステロール $(4.1 \pm 31.1 \mathrm{mg} / \mathrm{dl})$ 、中性脂 肪、体重 $(0.7 \pm 4.4 \mathrm{~kg})$ の有意の増加は認めず、尿酸は 有意に下降した。年茂、調査開始時の血清コレステロー

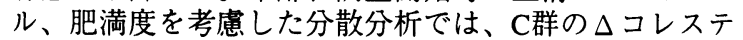
ロール、 $\Delta$ 中性脂肪、 $\Delta$ 体重、 $\Delta$ 尿酸が、他群に比較し 有意に小さかった。 $\Delta$ 血圧には差異を認めなかった。ま たC群では、常習的な飲酒、喫煙率が低く、定期的運動 実施率が高かった。さらに期間中の $\Delta$ 変化に対する多変

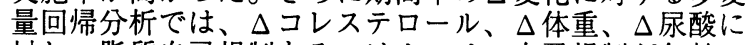
対し、脂質自己規制あるいはカロリー自己规制が年齢、 飲酒量、運動習慣とともに有意の説明変数として検出さ れた。

【結論】食事内容の自己規制が血清脂質、体重、尿酸の 長期的上昇を改善することを示した。 
241 高脂血症患者の食事療法におけるアポ $\mathrm{E} の$ 影響に ついてーアポE 2、4、5、7を中心に一

弘前大学第 3 内科、村上 宏、松井淳、王澤直樹、 須田俊宏

弘前大学臨床検查医学講座、井上文楮、保嶋 実

[目的] 高脂血症患者において、食事療法による血清脂

質の変動をアポEフェノタイプの差異について検討した。 特にアポE 2、4、5、7を有する患者とアポ E 3 を有 する患者とを比較検討した。

[方法］１。当科の高脂血症患者のうち、入院または外 来で食事指導（カロリー制限食）を行った患者について、 治療前後 4 6 週の、血清脂質の変動を比較検討した。

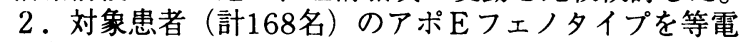
点免疫泳動法で決定した。

[結果] 1. 対象患者のアポEフェノタイプは、2/3 群 が12名、4/3 群が24名、2/4群が 8 例、 $5 / 3+$ $5 / 4$ 群が 9 名、 $7 / 3+7 / 4$ 群が 6 名、そして $3 / 3$ 群 が111名であった。

2. 総コレステロール值の改善は、E $3 / 3$ 群と比較し て、E $5 / 3+5 / 4$ 群、E $7 / 3+7 / 4$ 群、E $2 / 4$ の 群でともに低かった。中性脂肪值は、E $7 / 3+7 / 4$ 群 で治療前に高值を呈したが、食事療法に反応し良好な改 善をみた。それに対してE 5/3+5/4 群、E $2 / 4$ の 群では中性脂肪值の改善はみられなかった。

[結論] アポ $\mathrm{E} 3$ 以外の変異アポ $\mathrm{E}$ は、日本人に比較的 高頻度に認められるため、高脂血症の治療に際し、アポ Eフェノタイプを含めた質的診断が必要であると考えら れた。

【目的】従来より、大豆蛋白によるコレステロール低下作用につ

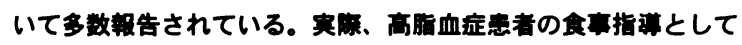
豆鹿などの大豆製品の撒取か推算されているにもかかからず、そ

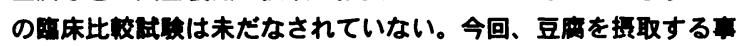



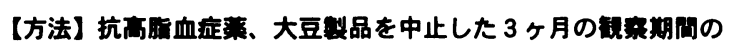

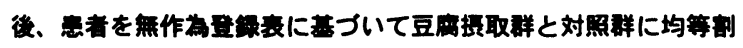

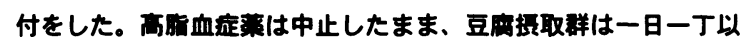

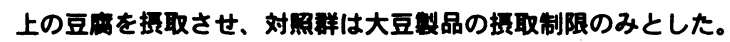

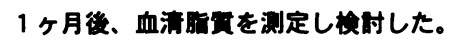

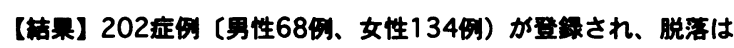
10 例(5.0\%)であった。豆麗拱取前德のTC、LDL-C、RLP-C、

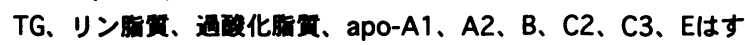
ベて5\%以下の变勒て $p>0.05$ であった。 L $p(a)$ は10.4\%( $p=$ 0.009)、NEFAは16.2\%( $\mathrm{p}=0.011)$ 增加した。HDL-Cは2.3\% $(\mathrm{p}=0.002)$ 塄加を慨めた。

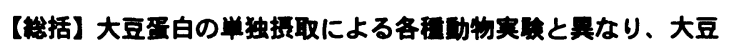

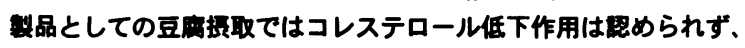

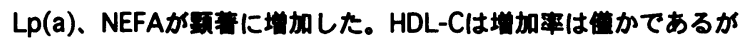

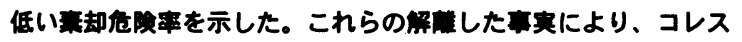
テロール低下作用を相数する大豆成分の存在が示晙される。
243

脂質低下作用を有する機能性食品開発の試み

- キトサン入り即席麺のLDL-コレステロール低下作用 -

1)滋賀医科大学第三内科, 2)同 栄養管理室, 3)日清食品株式会社中央 研究所食品開発部, 小島秀人”, 柏木厚典", 永井義夫", 山田臯 ${ }^{11}$, 中村 高秋", 栗原美香 ${ }^{2}$, 水野由佳 ${ }^{2}$, 畦西克己 ${ }^{22}$, 中西直子 ${ }^{21}$, 岩川裕美 ${ }^{2}$, 福井

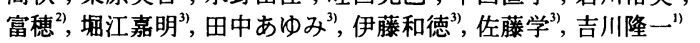

[目的] 甲殼類より生成される食品キトサンは、コレステロール吸収 を抑制することより、食事療法への応用が期待される。今回、キト サン含有スナック麺を作成し、高コレステロール者の食事療法に併 用し、その効果を検討した。[万法] 血清総コレステロール (T-Chol) が200-300 mg/dlである18人 (男16/女2) の未治療高コレステロール者 を盲検法にて2群に分類し、栄養士による食事指導後4週間の前観察 期、6週間の試験食摂取期及びその後3週間の後観察期でのT-Chol 、 中性脂肪 (TG) 、LDL-Chol、HDL-Chol、ApoA-I、Bを測定した。同 時に栄養士による食生活の変化を調査した。キトサン摂取群(キトサ ン群) はキトサン1g含有するカップ入り即席麺 (55g) を、キトサン非 摄取群 (プラセボ群) はキトサン非含有麺 $(54 \mathrm{~g})$ を、毎日一回主食と して6週間継続拱取した。なお、両者は外見からは区別できない。

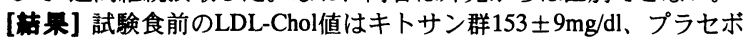
群 $143 \pm 11 \mathrm{mg} / \mathrm{dl}$ と両群間で差を示さず、試験食摂取にてキトサン群 $121 \pm 6 \mathrm{mg} / \mathrm{dl}(-20 \%) 、$ 、プラセボ群 $139 \pm 10 \mathrm{mg} / \mathrm{dl}(-2 \%)$ とキトサン群で 著明に低下し、両群間にも有意差が認められた $(\mathrm{p}<0.01)$ 。さらにキ トサン群ではT-Cholが13\%、ApoBが13\%有意に低下したのに比し、 プラセボ群では変化しなかった。またTG、ApoA-Iは両群とも変化せ ず、HDL-Cholはキトサン群で低下傾向を示すものの、摂取後両群間 に差がなく、過酸化脂質、ビタミン、電解質も変化しなかった。食 生活調査でもスナック麺導入による栄養素バランス及び健康志向に 対し影響しなかった。[結田] キトサン入りのスナック兡は食事療法 に併用することにより著明なLDL-Chol低下作用を示し、高コレステ ロール者への実生活に即した臨床応用が期待される。

\section{4 米油の血中コレステロール低下作用 \\ 川埼医療福祉大学健康体育学科 辻说子}

【目的】植物油による血中総コレステロール(TC)の低下は油脂を 構成する脂肪酸の影響が強い。中でもリノール酸の多いサフラワ 一油(S)がこれまで有用とされてきたがHDL-Cの低下ももたらすこ とが明らかになった。一方、植物油中の不ケン化物の影謷も大き く、不ヶン化物の多い米油(R)の血中TC低下作用も知られる。特 にRとSが7:3の調合油の血中TC低下作用は大きく、しかもHDL-C は低下しないことを被検者試臥の結果から既に報告してきた。そ こで、Rやその調合油の血中TC低下作用の機序を知るためにラッ トの血中脂質への影䇺を検討した。

【方法】SD系雄ラットを用いラードを脂質源とした高コレステロ

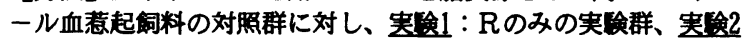
:RとSをそれぞれ100:0、70:30、50:50、30:70、0:100に混合した5 群、実検3：RとSをそれぞれ100:0、85:15、70:30、50:50、0:100に 混合した5群を設けた。実鍳期間は全て3週間とした。実䋡終了後 約10時間絶食させ、エーテル麻醉下で腹部大動脈穿刺により採血 した。なお、実験1・3では実検期間中の血洯TCの経日変化も調べた。

【結果】いずれの実絤も飼料掫取量、体重増加量や終体重に群間 の有意差はなかった。実検1では、対照群の血中TCは著しく上昇 したが米油群では明らかに低下した。実鉰2、3では対照群の血中 TCの高値に比べ、RとSの混合比70:30の群で顕著に低下し、R を50\%以上含む調合油の実険群でも低下した。HDL-Cは対照群で 最も減少し、Rを含む実倹群では増加した。

【結論】Rの血中TC低下作用はラットでも明らかに示され、脂肪 酸以外の要因として、各種の不ヶン化物の影臸が大きいものと思 われ、R中の不ヶン化物につき更に検討を要すると考えられる。 


\section{LDL の参加に及ぼす catechins の影響}

神戸大学·医·保険学科，同第一内科 †

五味川修三, 石川雄一, 内 正子, 土肥加津子, 谷口隆弘 †

【目的】近年，酸化 LDL は動脈硬化発症の一要因と考えられてい る。一方，お茶 catechinsは，抗酸化作用を有する事が知られている。 そこで，今回，LDLの参加の及ほす epicantechin (EC) と epigallocatechin gallate (EGCg) の影響を in vitro で検討した。さらに抹 茶飲用後における血漿 catechins 濃度と LDLの酸化 $\left(\mathrm{CuSO}_{4}\right)$ について も調べた。

【方法】LDL に対する EC， EGCg の抗酸化性は，被験者（健康な

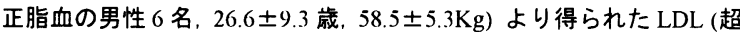
遠心分離法) に EC, $\mathrm{EGCg}$ を加え $5 \mu \mathrm{M} \mathrm{CuSO}$ 、で酸化した際の共役 ジェン及び，その lag time (234nm : Esterbauer 法), lipid hydroperoxide (LPO : 酵素法), agarose 電気泳動度から検討した。血㫽 catechins 濃度 は 12 時間空腹後の被験者に抹茶 $5 \mathrm{~g} / 200 \mathrm{ml}$ を飲用させた後，血浆中の catechins を酢酸エチルで抽出し HPLC (ODS-P-5 カラム) で分析した。 また，この時 lag time も調べた。

【結果】 $\mathrm{EC}(0.25,0.5,1.0,1.5 \mu \mathrm{M}), \mathrm{EGCg}(0.25,0.5,1.0 \mu \mathrm{M})$ は 浱度に依存して $\mathrm{CuSO}_{4}$ による LDL $(50 \mu \mathrm{g} / \mathrm{ml})$ の酸化を抑制し共役ジ エン，LPO の生成を減少させ， lag time を增加させた。また， EGCg は，EC と比べて lag time をより增大させた。LDL の agarose 電気泳動 度についても，EC，EGCg とも LDL の mobility を減少させ，その効 果は EGCgでより強かった。抹茶飲用後血壯中に catechins が钼察さ れ， lag timeについては増加する傾向を示したが，個人差が認められ た。

【結論】緑茶成分である EC，EGCg は in vitro において LDL の酸 化を抑制した。抹茶の飲用は in vivo において LDL の酸化を減少させ 可能性がある。

\section{6 くさや長期摂取における動脈硬化・脂質パラメーターへ の影響（八丈島住民の疫学調査の検討）}

福生吉裕 1 )、佐藤朋子 2)、平野勉 3)、足立満 3)、板部洋之 4) 日本医科大学 第二内科 1) 日本未病医学研究所 2)

昭和大学医学部第一内科 3) 帝京大学薬学部 4)

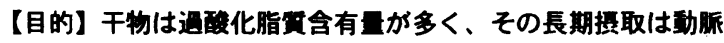

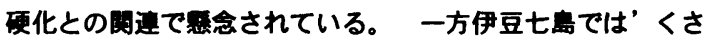
やという独特の干物か瑷用されているが長期㮛取者の疫学調 查は知られていない。今回八丈島住民においてくさや長期摄取

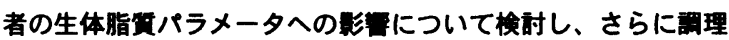
による模村も加えたのて報告する。【方法】1)住民模路時に间 診にてi)長期高雅度提取群，ii)非提取群を抽出した。2)各群の

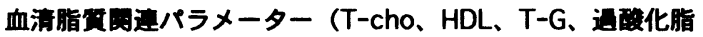

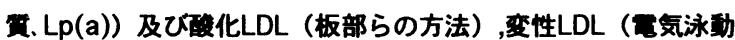
移動度）を模时した。3）くさやの成分分析を（生）と（焼 く)で行った。【結果】 808 名の解检者のうち高颣度晎取样 （每日，10 年以上）は23名、非提取者は22名胃いだされた。

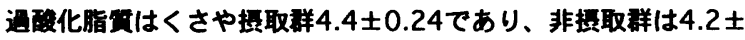
0.42士と有畫差は概められなかった。他の脂宽バラメータ， LDLの策泳勤上移勒度も有意差は見られなかった。酸化LDLは

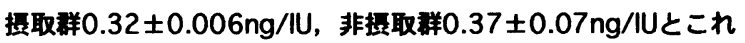

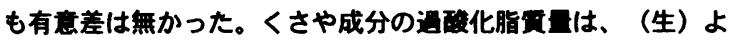

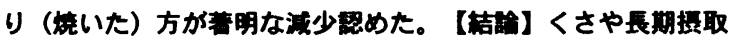



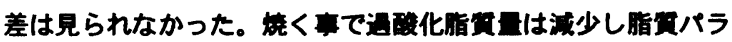
メーターへの影零は少なかったものと示睖された。
247 血清レムナント様リポタンパクコレステロール (RLP-C) に对する運動療法の効果

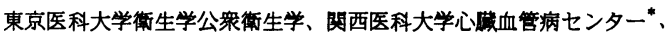
日本抗体研究所 $(\text { 株 })^{* *}$

高波嘉一、下光耀一、木村 秘"、川合ゆかり、中野隆光"*，勝村俊仁

【目的】レムナント粒子はLDL之同様、動脈硬化の形成に深く関与するリ术 タンパクである。運動はトリグリセライド(TG)代斯を促進し、リポ蛋白代鿾 に好ましい影䇺をおよぼすとされているか、レムナント粒子に対する効果に ついてはほとんど報告がない。そこで今回血清 RIP-C檤を指標として、3ヶ 月間の運動療法が血清中レムナント粒子におよぼす影䈏について検討した。

【方法】血清RLP-C值が基汼值の $7.5 \mathrm{mg} / \mathrm{d}$ 以上を示し、大阪简易保换総合健 診センターにおいて運動庱法を希望した中高年者31名（男性9名、女性22名、 平均年龄54.2歳）を対象とした。対象者全員に運動負荷武倠を施行して嫌気 性代斯間值(AT)を求め、AT時の心拍数を運動処方に用いた。運動療法のプロ グラムは有酸素運動を 30 分、ストレッチ等を 30 分で合計60分間、週 2 回、3ヶ 月間実施した。採血は運動㞠法開始前と実施 3 ヶ月後の一晚絶食後早朝空腹 時に行った。血清RLP-Cは抗アポA-I、抗アポB-100抗体固相化イムノアフィ ニティーゲルに血清を添加し、非結合分画中のコレステロールを湘定するこ とにより求めた。さらに血清高レムナントの原因の1つとされるインスリン 抵抗性に対する効果ついても检討した。

【結果】 3 ヶ月間の運動㙩法により、血糖值、血清インスリン湌度は有意に 低下し、インスリン抵抗性の指標であるHOMA-Rは運動療法前 $2.76 \pm 1.91$ 、 運動療法後 $2.09 \pm 0.91$ と有意な改善か認められた $(\mathrm{p}<0.02) 。 一$ 方、血清総コ レステロール值、HDLコレステロール值に有意な変化は認められなかったか、、 血清 $\mathrm{TG}$ 值は有意な低下を示した $(133.0 \pm 40.5 \mathrm{mg} / \mathrm{dl}$ vs. $116.9 \pm 40.6 \mathrm{mg} / \mathrm{dl}$, $\mathrm{p}<0.05$ )。また血清RLP-C值は運動療法前 $11.4 \pm 3.8 \mathrm{mg} / \mathrm{d}$ であったが、運動療

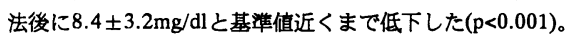

【結論】有酸素運動を中心とした運動療法は、インスリン抵抗性を改善する だけでなく、血清 TG值およびRLP-C值を低下させ、血清高レムナントの改善 に有効である可能性が示唆された。

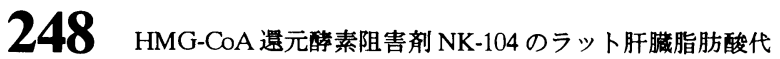
謝に及ぼす影響

(宮崎大学農学部 ${ }^{1}$ 、佐賀医科大学代謝分泌内科 ${ }^{2}$ ) 福田亘博 ${ }^{1}$ 、 窄野昌信 ${ }^{1}$ 、戸高直樹 ${ }^{1}$ 、後藤宏美 ${ }^{1}$ 、山本匡介 ${ }^{2}$ 、小川洋子 ${ }^{2}$

【目的】HMG-CoA 賟元酻素阻害郕である NK-104 の血清トリグリ セリド (TG) 濃度低下作用の機序を解明するため、ラット肝臟にお ける脂肪酸代謝を調べた。

【方法】ウィスター系雄ラットを用いて単離肝臓灌流実験を行った。 外因性脂肪酸として ${ }^{14} \mathrm{C}$-オレイン酸を灌流開始時に $100 \mu \mathrm{mol}$ 、その 後 1 時間当たり $90 \mu \mathrm{mol} / \mathrm{h}$ 連続的に添加した。 NK-104 は、1\%DMSO を含む $0.9 \%$ 生理食塩水に溶解し、灌流開始時に $8 \mu \mathrm{mol} 、 1$ 時間ごと に $2 \mu \mathrm{mol}$ 添加した。肝臓からの脂質分泌量、ケトン体生成量、肝臓 脂質濃度、各脂質画分への放射能活性の取り込みを測定した。

【結果】 ${ }^{14} \mathrm{C}$-オレイン酸の肝臟による取り込みは、両群間で差異は なかった。NK-104 は、ケトン体生成量およびケトン体への ${ }^{14} \mathrm{C}$-オ レイン酸の取り込みを增加させる傾向を示した。一方、肝臟からの $\mathrm{TG}$ 分泌量および ${ }^{14} \mathrm{C}$-オレイン酸の灌流液 TG への取り込みは、 NK-104 添加により著しく減少した。肝臓 TG 濃度も同様に減少した。 ${ }^{14} \mathrm{C}$-オレイン酸の酸化系とエステル化系の代謝運命の解析から、 NK-104 は、外因性脂肪酸の酸化系への代謝を六進させ、一方、エス テル化系への流れを減少させることが明らかになった。以上の結果 から、NK-104 投与による血清 TG 濃度の低下は、肝臟における脂肪 酸代謝の变化を介して引き起こされていることが示唆された。 
249 HMG-CoA 還元阻害剂(HCRI)による筋細胞死のシグナル伝 達機構

福井医大第 2 内科 中川広人、武藤多津郎、熊野貴規、栗山 勝

目的 : HCRIは、副作用として横紋筋融解症などの筋障害を引き 起こすことが知られている。我々はその発症機序を解明するため にラット筋細胞L6 myoblasts (L6)をモデル系としてHCRIの 1 つで あるsimvastatin (SV)を用いて L6細胞内情報伝達系に及ぼす影響を 検討し、同薬䯇により筋細胞にapoptosisの誘導があり、その細胞 死のシグナル伝達のメカニズムに、Rasを介した

phosphatidylinositol-3-kinase (PI3K)の活性低下が重要な役割を果た す可能性を報告してきた。今回は、その機序解明のためRasおよ びPI3Kの細胞内局在変化を検討した。

方法：L6に種々の濃度の SVを投与し、Rasのプロセシングおよ びPI3Kの活性を検討した。PI3Kの活性は、110kDの触媒サブユニ ット(p110)、85kDの調節サブユニット(p85)およびRasに対する抗体 を用いた免疫沈降物で行い、各々の免疫沈降物はさらに上記の 3 種の抗体を用いてウェスタンブロットを行った。また常法により 細胞質画分と細胞膜画分に分け、それぞれの画分について同様の 检討を行った。さらに、L6を SV、30 $\mathrm{g} / \mathrm{ml}$ で 10分間処理し、常 法に従い免疫組織染色を行った。1 次抗体性抗pan-Ras 抗体、2 次抗体にはFITCでラベルされた抗マウス免疫グロブリン抗体を用 い、共焦点レーザー影微鏡及び蛍光影微鏡で観察した。

結果：SV投与により1) 細胞質分画の Ras とp110が增加した。2) 細胞膜分画の Rasに結合する PI3Kの活性が低下した。3)Rasの細 胞内局在の変化も免疫組織学的に確認された。

考察 : Rasの翻訳後修飾に伴う細胞内局在がSVにより変化する 可能性が示唆され、本菜剂による細胞死の発症機構の一因と考え られた。 福岛県立医科大学第一内科石橋敏幸、永田兼司

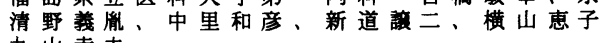
丸山幸夫

帝京大学医学部内科寺本民生

【目的】プラーク破綻時の血栓形成は急性冠趿脈症 候群の病態に檑めて重要であり、組織因子( $\mathrm{t}$ is sue factor:TF) とプラスミノゲンアクチベーターイン 七ビタ一 ( PAI-1) は易血栓形成性に深く関与してい る。 H M G-CoA 還元䤃阻害菜プラバスタチンの大 規模臨床試略においてコレステロール值を除外して も、対照群に比較しプラバス夕チン群で心血管イベ

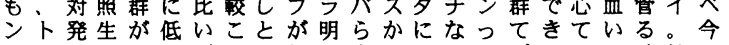
回その文力不台を解明するためにプラーク破輐に

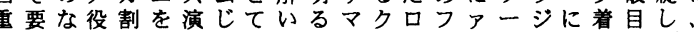
マクロファージのTFおよびPA I-1 産生能に及ほす プラバスタチンの影䈏を徐封した。

【方法】健常人末梢血より単球を比重遠心法および プラスチック付着法にて分離した。得られた細胞は CD $14 、$ CD 36 名ほほ100\%の細胞で、同種 LPDS $(2 \mathrm{mg} / \mathrm{ml})$ および酸化 $\mathrm{LDL}(100 \mu \mathrm{g} / \mathrm{ml})$ の存在下

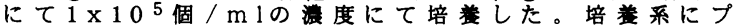
ラバスタチン $(100 \mathrm{ng} / \mathrm{ml} \sim 10 \mu \mathrm{g} / \mathrm{ml})$ を添加し、 培美上清のTFおよびPAI-1を 1 E L ISA 法にて経時 的测定した。

【結果】プラパスタチンは培美 3 日（day 3 )以降に マクロファージから産生されるTF、PAI-1 湿度を 有意に低下させ、1 $10 \mathrm{mg} / \mathrm{m} 1$ の湌度で最大活性を 示した。TFはd a y 3 で $16 \%$, d a y 7 で $22 \%$ の低下 を認め $(\mathrm{n}=4) 、 \mathrm{PA} \mathrm{I}-1$ はd a y 3 で $28 \%$, d a y 7 で $22 \%$ の低下を認めた $(\mathrm{n}=5)$ 。

【結論】ブラバスタチンはヒト単球由来マクロファ 一浮のTF、PAI-1産生を娍少させた。プラバス多 チシによる心血管イ令卡登生㧕制効果のメ力三ス ムのひとつとして、プラバスタチンがプラーク内、 クロファージにおける易血栓形成性を抑制する可能 性が示睃された。
251 Fluvastatinの培養血管平滑筋細胞におけるangiotensin II 誘発superoxide生成の抑制効果についての検討 福岡大学第二内科 ${ }^{1}$ 臨床検查医学 2 )

久木真理 ${ }^{1,2)}$ 、松永 彰 ${ }^{1)}$ 、小野順子 ${ }^{2)}$ 、佐々木 淳 ${ }^{1)}$ 、荒川規矩男 ${ }^{1)}$

[目的] 枵状動脈硬化は、酸化LDL/泡沫化マクロファージの形成 により発生し、進展することが知られている。in vitroでは、 angiotensin II(AG II)が、マクロファージを含む種々の細胞に作用 し、superoxide生成により酸化LDLの形成に関与していることが示 唆されている。HMG-CoA還元酻素阻害薬であるfluvastatinはLDL 低下作用に加え抗酸化作用が示唆されている。今回は、fluvastatin によるAG II 誘発酸化ストレス抑制効果を検討した。

[万法] 培養血管平滑筋細胞（正常ヒト大動脈血管平滑筋細胞: HASMC) にAG II 100nMを添加し、同時にfluvastatinまたは simvastatinを加え、24時間後にlucigenin chemiluminesence法に て、生成するsuperoxideを測定した。

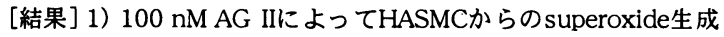
は投与前の約3倍誘発された。2）約3倍に增加したsuperoxideの生 成は、 $50 \mathrm{nM}$ fluvastatinにより平均 $30 \%$ 抑制され、100 nM fluvastatinでは平均 $52 \%$ 抑制された。3) $100 \mathrm{nM}$ simvastatinでは superoxide生成の抑制効果はみられなかった。

[結論] fluvastatinは生理的浱度て AG 誘発superoxideの生成を 抑制することが示唆された。

\section{2}

フルバスタチンの抗酸化作用ーヒト前骨饸球系細胞と ヒト血管内皮細胞を用いた検討

東京女子医科大学内分泌センタ一内科

宇治原 誠、野村缓、高松 めぐみ、出村博

【目的】フルバスタチン(Flu)はコレステロール低下作用に加え、 LDL酸化抑制などの抗酸化作用を示すことが報告されている。今 回我々は、(1)FluがMфからのスーパーオキサイド $\left(\mathrm{O}_{2}\right)$ 放出を抑制 するか否か、(2)ラジカルによる酸化的細胞障害をFluが抑制する か否かを検討することを目的として、ヒト前骨随球系細胞(HL60) の高分化能 subline (HL60/DU-1)とヒト腤帯静脈血管内皮細胞 (HUVEC)を培養し、Fluおよびその代謝物を添加し実験を行った。 【方法】 $\mathrm{HL60} / \mathrm{DU}-1 を 1 \alpha, 25(\mathrm{OH})_{2} \mathrm{VD}_{3}$ でM $\phi$ 様細胞へ分化誘導し、 Fluおよびその代謝物を培養上清に添加し、PMA刺激による 出に対する効果を検討した。 $\mathrm{O}_{2}$ はルシフェリンアナログ(MCLA) およびnitro blue tetrazolium (NBT)を用いて測定した。またHUVEC を培養し細胞内oxidative activityのプローブであるCM- $\mathrm{H}_{2} \mathrm{DCFDA}$ をloadした後、水溶性ラジカル放出剤のAAPHを添加し、細胞内 oxidative activityを蛍光影微鏡による観察と蛍光ブレートリーダー による虽光強度の経時的な測定で検討した。またAAPH添加後の 細胞内GSHも測定した。Fluおよびその代謝物を培養上清に添加 し、AAPH添加後のoxidative activityおよびGSHの変動に対する効 果を検討した。【結果】Fluおよびその代謝物は、M $\mathbf{\phi}$ 様細胞へ分 化したHL60/DU-1からのO 2 放出を抑制した。またAAPHによる HUVECのoxidative activityの増加とGSHの低下はFluの代謝物

（M2, M3）添加で抑制された。【考察】フルバスタチンとその 代謝物は $\mathrm{M} \phi$ 様細胞、ヒト血管内皮細胞を用いた細胞培養系で抗 酸化作用を示した。 
253 HMG-CoA還元醳素阻害䯇フルバスタチンの 抗酸化物代謝改善作用

大阪市立大学医学部第一生化学

○鈴村邦治，笠原恵美子，簡光章，王屹，井上正康

【目的】高脂血症における病態の悪化と酸化ストレスは密接な関 伱があると考えられる. 従って内因性抗酸化物による体内の還元 状態の維持は, LDLの酸化変性や動脈硬化初期病巣進展の抑制上, 重要と思われる. 我々は最近 Watanabe 高脂血症ウサギ(WHHLウ サギ)を用いた検討で，本病態下ではクルタチオン (GSH)及びア スコルビン酸(AsA)の代謝回転が抑制されていることを明かにし た. 今回, 高脂血症治療薬であるフルバスタチン(FLV)およびプ ラバスタチン(PRV)のWHHLウサギの抗酸化物代謝に与える影響 について解析した.

【方法】 WHHL ウサギ（5 ケ月踴，雄）に FLV，PRV を 30 $\mathrm{mg} / \mathrm{kg} / \mathrm{day}$ で 4 週間経口投与した. GSH の代謝回転速度はGSH の合成阻害剤（ブチオニンスルフォキシミン）を静脈内投与した 後の臓器中 GSH の半減期から解析した. AsA については, AsA の静脈内投与後の血中クリアランスを比較した.

【結果】FLVはWHHLウサギにおける GSH, AsA の代謝回転を著 明に改善した. 一方 PRVはほとんど作用を示さなかった. FLVに 認められた抗酸化物代謝改善作用のメカニズムに関しては解析中 であるが，両薬物は血根脂質レベルに関しては同程度の低下作用 を示していたので，主作用である脂質低下作用以外の化合物の特 徵であると考えられる。

【結論】FLVに認められた AsA, GSH の代謝回転改善作用は高脂 血症病態における体内の酸化罢元状態の改善に有用と思われる.

254 回渴胆汁酸トランスポーター(IBAT)阻害詴, S-8921の サルにおけるLDLコレステロール低下作用

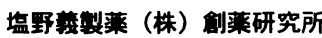

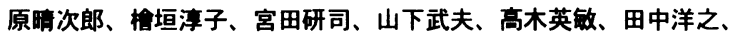
水井卓司

【目的】IBAT阻害郕であるS-8921の血清コレステロール低下作用 をサルを用いて検㣙する。

【方法】成熟雄性及び䧳性カニクイザルを実駼に用いた。S-8921

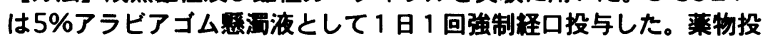
与の前後及び投菜期間中に採血を行ったか、投菜期間中は菜物投与 前に探血した。血海VLDL, LDL及びHDLコレステロールを超蚞心法 により測定した。烡便は操血の前日 1 日分を採取し、HPLC法により 胆汁酸含吾を測定した。また実検には同じサルを綝り返して使用し たが、 1 回の莱物処置終了後、次の莱物処置まで少なくとも 4 週間 の休乘を行った。

【結果】通常食铝育サルにS-8921(3-30 mg/ $\mathrm{kg})$ を10日間投与 すると用贯依存的にLDLコレステロールの低下が認められた（最大 21\%)。この時VLDL及びHDLコレステロールは不変であった。ま

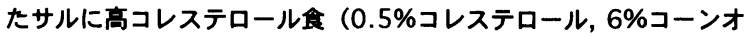
イル）を10日間与えるとLDLコレステロールが著明に上昇し、HDL コレステロールは低下した。S-8921 (30 mg/kg)の同時投与は、 LDLコレステロールの上昇を約 $50 \%$ 抑制し、HDLコレステロールの 低下をほほ完全に抑制した。コレステロール非負荷及び負荷のいず

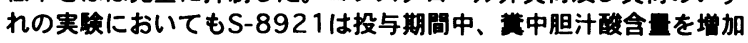
させた。

【結詥】S-8921は 1 日 1 回の経口投与で、IBAT阻害作用に基づく と考えられる強いLDLコレステロール低下作用を示し、高コレステ ロール血症の治瘃に有用であると考えられた。
255 コレステロール食角荷家鬼の実験的枵状硬化の対 するgliclazideの効果

名古屋大学大学院医学研究科老年医学

野村 秀樹、内藤 通孝、加藤 由利子、井口昭久

【目的】SU剤のひとつであるgliclazideは、その血糖降 下作用とは別に抗酸化作用を持つことが報告されており、 動脈硬化の進展に予防的に働く可能性が考えられる。今 回、我々は、コレステロール食負荷家鬼の実験的動脈硬 化においてその効果を検討したので報告をする。

【方法】雄性ニュージーランド白色種家兔を1\%コレステ ロール食にて10週飼育し、実験群（G群）には同時に gliclazide $20 \mathrm{mg} / \mathrm{kg} /$ day を投与した。10週後に血清コレ ステロール濃度( TC)、胸部大動脈における動脈硬化面積 \%、銅によるLDL酸化について lag timeを测定した。

【結果】10週後のTCはコントロール群 (C群)1134 1312 $\mathrm{mg} / \mathrm{dl} 、 \mathrm{G}$ 群 $1131 \pm 389 \mathrm{mg} / \mathrm{dl}(\mathrm{mean} \pm \mathrm{SD})$ と差を認めな かった。動脈硬化面積％は、C群38.8 $17.3 \%$ 、G群

$30.5 \pm 14.9 \%$ とG群にて平均值の低下を認めたが有意差

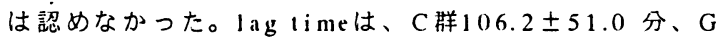
群 $145.2 \pm 44.2$ 分と、平均值はG群にて延長していたが、 有意差は認めなかった。

【結論】今回の実験では、動脈硬化面積％は平均值とし ては、低下を認めた。また、銅によるLDL酸化において lag timeの平均値の延長を認めた。これらから gliclazideが抗動脈硬化作用・抗酸化作用を有する可能 性が示唆された。

\section{6 コレステロール負荷ウサギにおける paclitaxel の} バルーン賃害後の内膜肥厚抑制効果

第一製薬(株) 創薬第二研究所

渋谷朋子、森下 敖、伊藤 綾、西田健一

【目的】抗癌剤である paclitaxel(Taxol)は、正脂血動物でパルーン 傷害後の血管内膜肥厚を抑制することが知られており、PTCA 後再狭窄予防効果が期待されている。しかし、正脂血動物の血 管病変は主に平滑筋細胞(SMC)から成り、脂質やマクロファージも 存在するヒ卜坫状硬化と質的に異なっている。本研究では、より ヒト病態に類似したコレステロール(Chol)負荷ウサギを用い、 paclitaxel の内膜肥厚抑制作用を検討した。【方法】 $0.3 \% \mathrm{Chol}$ 含有飼料 を雄性 NZWウサギに給慨し、2週間後に2Fバルーンカテーテルで左総

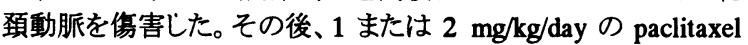
を計 5 回隔日投与し、甥害 3 週間後(実験開始 5 週間後)に内膜 肥厚度を評価した。また、ヒト大動脈由来培養 SMC を用いて細 胞増殖 $\left({ }^{3} \mathrm{H}\right]$ チシジン取り込み、MTTアッセ价よび転写因子 NFкBに対する paclitaxel の作用を検討した。結果】Chol 負荷と パルーン傷害により血管には SMC、泡沫化マクロファージ、細胞内外 脂質を含む内膜が形成された。Paclitaxel はいずれの用量でも 内膜肥厚を抑制した(I/M 值 39-47\%抑制、 p<0.05)。この効果は 内膜 SMC とマクロファージの両方の減少 $(\mathrm{p}<0.05)$ によるものであっ た。Paclitaxel $2 \mathrm{mg} / \mathrm{kg} /$ day 投与により末梢血好中球が著明に 减少したが、 $1 \mathrm{mg} / \mathrm{kg} / \mathrm{day}$ 投与では重篤な副作用は認められな かった。実験終了時の血清 Chol 值は 533-710 mg/dlで、各群 間に有意差はなかった。また、paclitaxel は培養 SMCにおいて、 血清刺激による細胞増殖 $\left(\mathrm{IC}_{50}=20-50 \mathrm{nM}\right)$ および NF-kB 活性 化を用量依存的に阻害した。【結語】Paclitaxel は高脂血動物 において、SMC のみならずマクロファージの内膜浸潤も抑制し、バ ルーン傷害後内膜肥厚を抑制することが示された。 
257 エンドセリンの動脈硬化におよぼす影穓

ーエンドセリン A受容体拮抗薬による検討一

奈良県立医科大学第 1 内科, “同薬理学

西野俊彦, 椎木英夫, 土肥和紘, 米谷行男 ${ }^{*}$, 中鴄敏勝 ${ }^{*}$

【目的】エンドセリンが動脈硬化を促進するか否かについて、エ ンドセリンA受容体拮抗薬 (R277) による大動脈硬化抑制作用の有 無から検討した.【方法】対象は，1\%コレステロール添加飼料 100g/日とR277を同時に 4 週投与した10週龄の雄日本白色家鬼30羽 である. 対象を, R277の投与量から $10 \mathrm{mg} / \mathrm{kg}$ /日 投与群 (DR10群) 10 羽, $20 \mathrm{mg} / \mathrm{kg}$ /日投与群 (DR20群) 10 羽，および $30 \mathrm{mg} / \mathrm{kg}$ /日投 与群 (DR30群) 10羽の 3 群に分けた. 対照は, $1 \%$ コレステロール 添加飼料のみを 4 週投与した 10 羽 (HL群)である．各群の上行大動 脈横断面での内膜/中膜面積比 ( I / M ), および内膜の泡沫細胞 1 個あたりの面積 ( SF )を算出した. また, 各群の上行大動脈を抗 エンドセリン-1抗体および抗マクロファージ抗体で免疫組織化学 的に二重染色した。【結果】 I / M は, HL群が $0.072 \pm 0.10, D R 10$ 群が $0.044 \pm 0.075$, DR20群が $0.027 \pm 0.053$, DR30群が $0.026 \pm$ 0.010であり，HL群に比してDR20群およびDR30群で有意に小で あった.しかし, I/ M は, HL群とDR10群の両群間, およびDR20 群とDR30群の両群間に差がなかった. また, SFは, HL群が243 士 $38\left(\mu \mathrm{m}^{2}\right), \mathrm{DR} 10$ 群が203士32, DR20 群が157士28, DR30群が 149 土21であり，HL群に比してDR20群およびDR30群で有意に小で あった.しかし，SFは，HL群とDR10群の両群間，およびDR20群 とDR30群の両群間に差がなかった. さらに, エンドセリン-1の発 現は, HL群, DR10群, DR20群, およびDR30群のいずれの群で も, 肥厚した内膜の泡沫細胞細胞質に観察された. 【結論】エン ドセリンA受容体拮抗薬は, 鬼大動脈の動脈硬化抑制作用を示し た. したがって，エンドセリンは動脈硬化を促進することが示㖫 される。

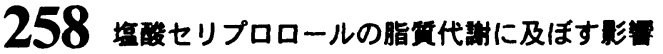 一特にLDLのサイズに及ほす影量—}

東邦大学医学部付属佐合病院内科、同䧗床検查医学*、国保国吉病 院**国保鋸南病院***

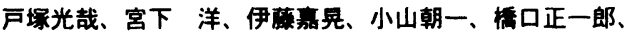

渡透 仁:、白井厚治*、伴俊明 $*$ 、石原弘行“*、山本和男”、川野 栄一郎"*、金親正敏"**、森上"***

【目的】ある程の $\beta$-blockerの使用によりLDLが小粒子化す ることが報告されている。今回我々はB2選択性の高いSAを

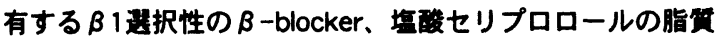

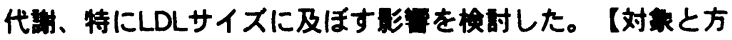

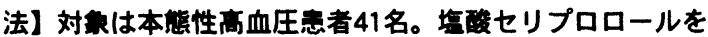
$200 \mathrm{mg} /$ 日投与し12迵にわたり血清脂而位、総コレステロー ル(TC), 中性脂肪(TG),HDLコレステロール(HDL-C),LDLコレ ステロール(LDL-C)とLDLサイスの変化を梌时した。LDLサ

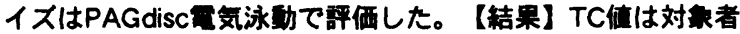
全体で投与4,8海後に有意に低下。高TC血者(TC>220 ms/d) では投与4,8,12迥後に有意に低下。TG值は対無者全体で有意 な变動は示さなかったが、高TG血者(TG>150mg/d)では投 与4,8迥後に有意に低下。HDL-C伹は有意な变勤は示さなか

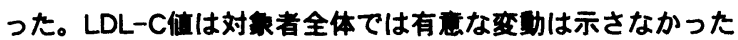
か、高LDL-C血者(LDL-C>150mg/d)では投与4,8,12週後に 有意に低下。LDLサイスは投与前に比し有意な变化は示さな かった。【教察】塩磞セリプロロールはLDLの柆子サイスに

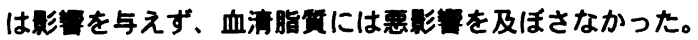

東京都老人医療センター循環器科、内分泌科“

上田清悟、片㭣真奈美、西村敬史、松本佳久、松下哲、荒木厚 * 井藤英亳”、小澤利男，折茂㹂

【目的】高脂血症患者では血小板凝集が充進する。今回、老年者 高脂血症において抗高脂血症莱により、血小板の $\mathrm{N} O$ 依存性凝集 の改善を認め、その機序について検討した。

【方法】本院入院及び外来の老年者高脂血症 ( $\mathrm{TChol} \geqq 240$ $\mathrm{mg} / \mathrm{dl})(\mathrm{n}=8$, 平均年齢 78 藏）および正常脂澌の老年者 $(\mathrm{n}$ $=16$, 平均年龄 75 藏) より 3 時間空腹安静状態で探血し、 platelet rich plasma (PRP)を得た。PRPのepinephrine血小板凝 集を测定し,0.1-2.5 m M L-arginineの血小板准集抑制を $\mathrm{N} O$ 依 存性血小板凝集抑制とした。また、抗高脂血症菜（シンバスタチ ン、ブラバスタチン) 服用開始3个月後に同様の測定を行った。

【結果】(1) 正常脂贺の老年者コントロール（血中TChol 201 $\pm 40 \mathrm{mg} / \mathrm{dl})$ では、0.1-2.5mM L-arginineに対し容是依存性に血 小板凝集抑制（100\%凝集抑制）を認めた。高脂血症患者（266 $\pm 28 \mathrm{mg} / \mathrm{dl})$ では、 $2.5 \mathrm{mM}$ L-arginineに対し $53 \pm 14 \%$ 凝集抑制 を示した（p<0.01 vs コントロール）。(2) 抗高脂血症菜服 用開始 3 个月後では、高脂血症患者 (服用後 $219 \pm 50 \mathrm{mg} / \mathrm{dl}$ ) て $2.5 \mathrm{mM}$ L-arginineに対し86士7\% と数集抑制の改善を示し た（ $\mathrm{p}<0.02$ vs 服用前）。(3)PRPへの抗高脂血症菜の添加で は7\%にのみ准集抑制の改善がみられた。

【結論】老年者高脂血症はL-arginine依存性血小板凝集抑制異常 を示し、血小板自身の N O 産生低下を示した。抗高脂血症薬によ り凝集抑制異常は、改善された。准集抑制改善効果は抗高脂血症 来の抗酸化作用よりも、血中脂䓄の低下作用による方がより強い ことを示した。抗高脂血症莱による血小板抑制への作用は、冠動 脈の再狭察の抑制効果の機序を示すものと考えられる。

260 維持透析患者のシャント不全の病理組織学的検討 静脈血管壁の特徵的閒塞性動脈硬化病変とその薬物療法

医諴会クリニック

松井 豊

【目的】シャント不全は毎回の血液透析で綝り返される採血針の 穿刺による血管堲伤害・血栓形成とその修復で生じた狭窟性病変 のために血流量が不足し、透析困覲に宿いる病怒で維持透析患者 のQOLを著しく低下させる合併症のひとつである。その病理組織 学的検砷と薬物療法について検討したので報告する。【方法】シ ヤント造影や手術所見により伆合部や僈性的直接穿刺部位以外 の閉塞が原因であったシャント不全 22例(男 11 女 11 平均 59.3歳) を対象とし、病理組織標本の染色法はHE. Azan Elastica-VanGieson Aldehyde-Fucsin HE·Kossa反応重染色とマウス抗 $\alpha$-actinモノクロ 一ナル抗体(American Research Product 社弊)を用いた西秦抗体法に よる染色である。また全症例の末梢白血球より抽出した DNA を 用いて PCR を実施し、得られた PCR 産物をアガロースゲル電気 泳動法により ACE 遗厷子多型(DD、II，ID)を検出した。【結果】シ ヤント不全の病変血管は全例で三同權造を示す功脈化静脈であ つた。血栓を伴う惯性觧脈炎で内膜は著しい線維性肥厚で泡沫化 緇胞を認めないことと線維性硬化を伴う出血性外膜炎が特徽的 であった。中膜の平滑施細胞は腫大や変性、増殖と様々な形態を 示し、平滑筋細胞が肥厚内膜で壇殖した像も抗 $\alpha$-actinモノクロー ナル抗体による免疫組織化学標本で得られた。ACE遗伝子多型は II と ID各 10 例で DDはなかった。【結倫】紼り返された穿刺が起 因する持䌇した血管炎が血管保萑因子が枯渴した維持远析患者 の特殊な条件から血管病㚆を意起したのであろうと推測された。

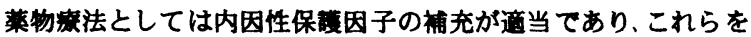
阻害する菓凨は投与すべきでない。 
261 糦尿病性内皮機能障害と ACE 阻害薬(キナプリル)及び ATII type1 受容体拮抗薬(GA0113)の血管抁張能改善

大阪大学第四内科

松本圭子 森下童一 守口篤 晹井則夫 檜垣実男 荻原俊男

環境バイリス 左近上博司

<目的>糖尿病性動脈硬化進展のトリカーーとして高血糖による内 皮機能障害は重要であるが、その分子機構は未だ明らかてない。 我々は、培義ヒ十内皮細胞を用いて高グルコース添加により内皮特 異的增殖因子である HGF 産生低下が内皮甥害に関与していること を報告した。(Diabetes, Diabetologia)また、糖尿病モデルマウスにお いて局所 HGF 産生低下も明らかにした。(J.Hypertension)本研究て は、まず精尿病モデルラットへの ACE 阻害薬及び ATII type1 受容 体楛抗薬投与による内皮機能改善について検封した。

<方法>16 週令雄性 SHR にストレプトソシン (STZ) $45 \mathrm{mg} / \mathrm{kg}$ に て糖尿病を誘発し、10 日後より ACE 阻害薬(キナルプリル; $10 \mathrm{mg} / \mathrm{kg}$ ) 及び ATII type1 受容体拮抗薬(GA0113; 0.1 $\mathrm{mg} / \mathrm{kg}$ )を経口にて 28 日間 投与した。非㓋血的に血圧測定後、䑏器を摘出し大動脈におけるア セチルコリンに対する驰髣反応を測定した。

〈結果〉投与後各群での血糖值の変化は認めなかった。アセチルコ リンによる内皮依存性の血管払張反応は対照群に比しキナルプリ ル投与群及び GA0113 投与群で同程度に洪度依存的に有意に改善 していた(P<0.01)。また、昖張反応は L-NAME 前処理において消 失した。<結論>栯尿病性内皮機能障害は、ACE 阻害薬及び ATII type1 受容体楛抗薬により血桾值に影䈐を与えることなく局所 ATII の内皮機能低下への関与が糖尿病においても考元られた。また ATII が局所 HGF の抑制因子であることより、ATII による局所 HGF の 関与が考光られた。

262 2型糖尿病患者の頝動脈内膜・中膜複合体発症 ・ 進展に対するスタチン系薬剤の抑制効果

国立熊本病院糖尿病センター, *熊本大学代謝内科 小堀祥三, 高橋毅, 竹村亭*, 松村岡 *, 阿南敬親*, 堺政和*,笹原誉之*, 七里元亮*

【目的】スタチン系䒩剤の血清コレステロール低下作用 以外の動脈硬化抑制効果を, 高コレステロール血症を伴 亏2型糖尿病患者を対象とし頝動脈内膜・中膜複合体 (IMT)を超音波法にて計测することにより検討した。

【方法】対象は年齢, 罹病期間, BMI, 血糖コントロール をマッチさせた高コレステロール血症を有する2型糖尿 病患者をシンバスタチン投与(S)群(10名)とプラバスタチ ン投与(P)群(10名)の2群に分割, 正コレステロール血2型 糖尿病(C)群(10名)をコントロールとし投与前と投与 1 年 後の成績を比較した。䅡動脈IMTはToshibaパワービ ジョンSSA370A, プローベ7.5Mhzを使用し, 超音波法に より評価した。【成績】S群とP群のTCは投与2ヶ月目に C群のレベルに達し, 以後 1 年間継続した。3群間の血糖 コントロール, HbA1cおよび神経伝導速度に有意の変化 はなく, 網膜症および大血管合併症の增悪もみられな かった。3群間の1年後の左右および平均頝動脈IMTは相 対的にS群, P群, C群の順に上昇した。C群の左および平 均頝動脈IMT增加率 $2.77 \pm 1.19 \%$ と $2.55 \pm 0.90 \%$ に比し, S群の左および平均䅡動脈IMT増加率はそれぞれ $1.30 \pm$ $0.87 \%(\mathrm{p}<0.01)$ 己 $1.27 \pm 0.55 \%(\mathrm{p}<0.01)$ 己有意に低値 ( $\mathrm{p}<0.01)$ を示した。P群とC群の左右および平均䅡動脈 IMT増加率の間には有意の差は認められなかった。【結 論】血清コレステロールをC群のレベルまで下げたとき スタチン系薬剤に頝動脈IMT増加率の減少がみられたこ とからコレステロール低下作用以外の動脈硬化抑制効果 が示唆され, 特に, S群において顕著であった。
263 糖尿病合併高脂血症患者における䅡動脈肥厚に対する HMG-CoA 還元醉素阻害薬の効果

東北厚生年金病院 糖尿病科

鈴木 研一、木村 真人

【目的】コントロール良好な糖尿病を合併した高脂血症患者を対 象に、HMG-CoA 還元醉素阻害剤（simvastatin）による血清脂質改 善作用が動脈硬化の進展抑制、退縮に有効かを顗動脈超音波断層 法(CAUS) を用いて検討する。

【方法】血清総コレステロール (TC) 值が $220 \mathrm{mg} / \mathrm{dl}$ 以上 $260 \mathrm{mg} / \mathrm{dl}$ 以下、HbAlc が $8 \%$ 以下の糖尿病患者 35 例を simvastatin $5 \mathrm{mg} /$ day 投与群 $(A$ 群 : $n=19)$ と非投与群 (B 群 : $n=16)$ に分け、試験開始前 および $1 、 3 、 6 、 12$ ヶ月後に血清脂質、12 ヶ月後にCAUSを施行した。 C 群として、高脂血症非合併例 17 例についても同様の検查を実施 し、3 群での血清脂質および内膜中膜複合体厚 (IMT) の変動を比較 検討した。

【結果】A群では 1 年間で、TC, LDL-C はそれぞれ平均 14. 3\%,25.6\% と共に有意（ $\mathrm{p}<0.001 ）$ の低下を示したが HDL-C および TG には有 意の変動を認めなかった。 $\mathrm{B}, \mathrm{C}$ 群では血清脂質にいずれも変動 は観察されなかった。血圧、HbA1c 等他の検査值には 3 群共に有 意の変動を認めなかった。I M T はA 群で $1.33 \pm 0.40 \mathrm{~mm}$ から 1.07 $\pm 0.31 \mathrm{~mm}$ 一と有意 $(\mathrm{p}<0.01)$ の減少を示し、B 群では $1.23 \pm 0.45 \mathrm{~mm}$ から $1.16 \pm 0.41 \mathrm{~mm}$ 、C 群でも $1.08 \pm 0.43 \mathrm{~mm}$ から $1.02 \pm 0.20 \mathrm{~mm}$ へと若干の減少を認めたが、共に有意の変動ではなかった。血清 脂質の変動と I M T の変動の関連性については、A群での $\Delta$ LDL -C と $\Delta$ I M T $(r=0.636 、 p<0.01) 、 \% L D L-C$ と\% I M T $(r=0.598$ 、 $\mathrm{p}<0.01)$ に有意の正相関を認めた。

【結論】糖尿病合併高脂血症患者における動脈硬化の進展・退縮 には LDL-Cの関与が示唆されるが、LDL-C の低下のみでは説明でき ず simvastat in の血清脂質改善作用とは別の抗動脈硬化作用の存 在も考えられる。

\section{4}

高コレステロール 血症に対するプラバスタチン治療によ る血管 extracellular superoxide dismutase の增加 産業医科大学第二内科、岐阜薬科大学臨床㔨郕学研究室 太崎博美、量川 毅、山下和仁、長井善孝、宮本雅治、上田しのぶ、 中島康秀、足立哲夫'

【背景】HMG COA遗元醍素阻害郕は、虚血性心疾患の予後を改善 することが認められている。内皮依存性拡張反応の改善は、心血管 病変の key event であると考えられているが、その機序について は、コレステロール低下作用の他に、内皮機能改善、血小板凝集抑 制など多方面にわたっていると推測されている。我々は、ヒトの動 脈に広く存在し super oxideを不活性化することでNitiric oxide(NO) の bi cavail ability を保持する機能を持つと考えられる extr acellul ar super oxide di smutase (EC-SOD) が、プラバスタ チン投与で增加するとの仮説を検証した。【方法】30名の type $1 \mid \mathrm{a}, \| \mathrm{l} b$ の高コレステロール血症患者（男性16名、年齢 56.5藏） に対して12-60週（平均 39週）プラバスタチン 10-20 $\mathrm{mg}$ を投与し 12 週毎に, 血清、リポ蛋白分画のコレステロール、 中性脂肪、アポリポ蛋白を測定し、同時に EC-SOD（ヘパリン 1 $00 \mathrm{U} / \mathrm{kg}$ b.w. 投与前後の血中浱度の差=内皮結合EC- SOD) を測 定した。EC-SODは、ELISA法（抗ヒトEC-SODモノクローナル抗 体）を用いて測定した。【結果】プラバスタチン治療により、 LDLコレステロールは、 $150.3 \pm 42.0(\mathrm{mg} / \mathrm{dll})$ から $135.4 \pm$ 45.8 $(\mathrm{mg} / \mathrm{dll})$ へ有意に低下した $(\mathrm{p}=0.03)$ 。EC-SODは、LDL コ レステロール $(r=-0.360, p=0.048) 、 ア ホ ゚ B ~(~ r=-0.453$, $\mathrm{p}=0.011)$ と有意に正相関して增加した。【考察】血管間質に存 在する EC- SOD のプラバスタチン治療による增加は、NOの bi oavailability に寄与すると考えられ、血管に対する酸化的ス卜 レスの防御機構の增強により内皮機能を保持し、生命予後の改善に 寄与している可能性があると考えられた。 
265 フルバスタチンによる血中過酸化脂䓄浱度と動脈硬化 惹起性リボ蛋白の低下とLDL の易酸化性の改善 埼玉医科大学第四内科 ○井上郁夫、後藤誠一、野地䀘、 熦興太、栗原進、片山茂裕、熊谷外科病院 山崎望人

【はじめに】最近虚血性心疾患の二次予防でスタチン系薬郕で あるフルバスタチン (Fluva) 投与により他のスタチン系薬郕に比較 し、冠動脈血管内腔の狭窄を著しく改善することが報告され(Herd JA et al: Am J Cardiol 80:278-286, 1997)、Fluva の抗動脈硬化作用 が注目されている。

【目的】今回我々は、Fluva を糖尿病を合併した高脂血症患者に 投与し、血中過酸化脂留源度(TBARS) と動脈硬化惹起性リボ蛋白 の低下とLDLの易酸化性について検討した。

【対象、方法】糖尿病を合併した高脂血症患者35名（プラバス タチン治療群 10 名、シンバスタチン治癔群 12 名、未治療群 13 名) にFluva を一力月間単独投与および变更し、投与前後で血中脂算漉 度を測定した。リボ蛋白分析は stepwise 超遠心法で行い、ディス ク電気泳動法 (リボフォー)にても分析し、我々の既法 (Inoue let al: Diabetes Care 19:1103-1107, 1996)の Gaussian fitting 法により midband LDL および small LDL をも評価した。さらにLDLの易酸 化性も測定し、TBARS、ヘバリン觧注後血漿のLPL 蛋白量 (EIA法、 マーキットF (PL) も測定した。なお、Fluva 投与によりTGの低下 が見られない症例にはべザフィブレート(Bf)の併用も試みた。

【成績】Fluva 投与により血清 TC、TG、LDL-C は低下し HDL-C は上昇し、超遠心法での LDL およびIDLは滅少した。また、 Gaussian fitting 法による small LDL は低下し、LDL の易酸化性は著 しく改善し、TBARS は低下した。加えてBf併用により LPL 作用 が增強し、small LDL および IDL は消失し、さらに LDLの易酸化 性は著しく改善した。なお、Fluva およびBf併用での投与前後で のCPK の有意な上昇は認められなかった。また、Fluva への投与 変更によりさらにTBARS は低下し、血清 TCの低下が認められな い症例でも TBARS は有意に低下した。なお、それぞれの群の治療 前後でHbA1cの有意な変化は認めなかった。

【結論】Fluva 投与は糖尿病合併高脂血症患者の動脈硬化性病変 の予防に有用である。

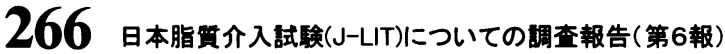 一登䱚された高脂血症患者 5 万例の 5 年间追跡結果の分析}

J-LIT研究会 板倉 弘重、島本 和明、及川 真一、齋藤 康、 中谷矩章、馬㴊宏、北徹、松澤佑次、松暗益德、佐々木淳、 他参画医 6,100名

【目的】高脂血症治療患者を6年間追跡し、血清脂質治療レベルと 虚血性心疾患発症頻度との関連について検討する。

【方法】対象は(1)血清総コレステロール值(TC): $220 \mathrm{mg} / \mathrm{dL}$ 以上 (2)性別:男性あるいは閉経後の女性、(3)年齢:35〜70歳の基準を 満たす高脂血症患者とし、登録した 5 万 2 千例全例に原則としてシン バスタチン $5 \mathrm{mg} /$ 日を投与し血清脂質值、臨床所見、および肝機能 検査等の臨床検査を行った。観察中に新たな疾患の発症等があっ た場合には記録し、服薬中止例については健在確認を行った。

【結果】登録例 52,670 例の内、投与 5 年後までの服薬継続例は 27,194 例、服薬中止例 22,794 例 (内消息不明 3,758 例)であった。

解析対象例における死亡例は752例で発現頻度は4.0/千人年、 心筋梗塞、狭心症と診断されたものが 607例で3.3/千人年であった。 死亡、疾患発症ともに二次予防例での頻度が高かった。副作用は 全体の $2.7 \% \quad 1,404$ 例の報告があった。

一次予防対象例では血清脂質值の変化率はTC值 $-20 \%$ 、TG 值-21\%、LDL-C值-30\%、HDL-C值＋10\%であり、長期に渡 り効果が維持されていた。筋梗塞の発症は治療後のHDL-C值が 高值ほど発症頻度が低い傾向が見られた。比例ハザードモデルで 有意相関が認められたのは高血圧症と糖尿病の合併であった。

【結語】近年、日本国内でも Evidence Based Medicineが求めら れているが、本試験の中間集計から、日本人の高脂血症治療にお ける目標値などの検討の上で、貴重なデータが得られることが期待 される。
267 職場における高脂血症管理に関する調査研究第一報： 食事療法と薬物療法の有効性の検討

一産推研・脂質介入試験 (Sansuiken-Lipid Intervention Trial) 日立製作所 (株) 日立健康管理センタ 中谷 敦他「S-LIT」研究会

【目的】産業労働者の高脂血症を対象とした前向きコホート研究 である S-LIT の、3 年次における有効性および安全性を検討する。 【方法】登録 1,563 例の中から安全性評価対象 1,445 例、有効性評 価基準を满たす 1,253 例を選択し、食事療法に HMG-CoA 還元醉 素阻害剂を併用する投薬群、食事療法群、無治療群における血清 脂質の推移、有害事象を検討した。

【結果】投薬群では治療 3 ケ月後から TC、TG、LDL-C の有意低 下、HDL-C の有意上昇が認められ、血清脂質の改善効果は 3 年間 にわたり安定していた。食事療法群においても3ヶ月以降 TC、 TG、LDL-C は有意低下したがその程度は投薬群に比し小さく、 HDL-C は推移の方向が一定していなかった。治療期間中における 投薬群の平均変化率は TC $-17 \% 、$ TG $-2 \%$ 、 LDL-C $-24 \% 、$ HDL-C $+5 \%$ 、食事療法群が TC $-5 \%$ 、TG $-2 \%$ 、LDL-C $-6 \% 、$ HDL-C $+4 \%$ 、 無治療群が TC $-2 \% 、 T G+10 \% 、$ LDL-C $-2 \% 、$ HDL-C - $1 \%$ であった。 登録值別の層別解析の結果、TC 值 $250 \mathrm{mg} / \mathrm{dL} 、$ LDL-C 值 $150 \mathrm{mg} / \mathrm{dL}$ 未満の症例では、投薬群では有意低下が認められたが、食事療法 群では有意変動はみられなかった。主なイベント発生は投薬群が 15 例(心血管系 10 例、脳血管系 3 例、癌 2 例)、食事療法群が 4 例 (脳血管系 1 例、癌 3 例)、無治療群が脳血管系 1 例の結果であっ た。投薬群における副作用は 10 例(1.2\%)、臨検值異常は 22 例(2.7\%) であった。

【結論】産業保健活動としての食事指導は高 TC 血症、高 TG 血 症を有意に改善することが認められたが、層別解析の結果では食 事療法には限界があり、TC 值 $250 \mathrm{mg} / \mathrm{dL}$ 以上の場合はさらに積極 的な薬物療法が必要である。また、産業労働者の高脂血症治療に 際しては、治療に対するレスポンスの確認や服薬コンプライアン スのチェックが必要と考えられた。

\section{8}

職場における高脂血症管理に関する調査研究第一報： 研究開始 3 年次における登録 1,563 例の解析結果

一産推研・脂質介入試験(Sansuiken-Lipid Intervention Trial) ソニー(株)健康開発センター 立道昌幸 他「S-LIT」研究会

【目的】日本人の一般労働者に適用できる脂質管理プログラムの 作成を目的とするコホート研究一産推研・脂質介入試験(S-LIT)を、全国の企業診療所 27 施設、31 産業医の参画により計画した。 本研究は 1994 年 1 月に開始し、積極的な健康管理活動を通して進 行中であるが、今回、現登録 1,563 例の解析結果について報告する。 【方法】各診療所における健診の結果、TC 值が $220 \mathrm{mg} / \mathrm{dL}$ 以上を 示す産業労働者を対象とし、食事療法に HMG-COA 還元酵素阻害 剤を併用する投薬群、食事療法群、無治療群の 3 群に分割し、各 群における血清脂質值と、血管系イベントの発生等を追跡する。

【結果】当研究に先立ち実施した 6,317 例の横断調査の結果では、 S-LIT 登録基準である 40 歳以上の男性労働者で TC 值 $220 \mathrm{mg} / \mathrm{dL}$ 以上の割合は $27 \%$ あっった。3 年次における登録状況は投薬群 721 例、食事療法群 446 例、無治療群 223 例である。登録時の平均年 齢は 3 群ともに約 49 歳で有意差はなかったが、BMI 值では投薬 群 $24.4 \mathrm{~kg} / \mathrm{m}^{2}$ と無治療群 $23.7 \mathrm{~kg} / \mathrm{m}^{2}$ との間に有意差がみられた $(\mathrm{p}<0.05)$ 。登録症例の TC 值は正規分布していたが、平均 TC 值 は投薬群 $278 \mathrm{mg} / \mathrm{dL}$ 、食事療法群 $260 \mathrm{mg} / \mathrm{dL}$ 、無治療群 $247 \mathrm{mg} / \mathrm{dL}$ といずれの群間にも有意差が認められた $(\mathrm{p}<0.001)$ 。平均 TG 值 にも有意差が認められ、投薬群 $240 \mathrm{mg} / \mathrm{dL}$ 、食事療法群 $228 \mathrm{mg} / \mathrm{dL}$ が無治療群 $184 \mathrm{mg} / \mathrm{dL}$ より高值であった $(\mathrm{p}<0.001)$ 。平均 HDL$\mathrm{C}$ 值には有意差はなく 3 群ともに約 $54 \mathrm{mg} / \mathrm{dL}$ であった。また、高 血圧、糖尿病、喫煙等の IHD 発症に対する危険因子の頻度も有意 に投薬群が高かった。

【結論】産業医現場における高脂血症治療薬の投与開始 TC 值は、 約 $270 \mathrm{mg} / \mathrm{dL}$ と高いレベルにあると考えられた。しかし、IHD 発 症に対するハイリスクの症例は D 群に割り付けられており、一次 予防対策に関する産業医の意識は浸透してきていると推察された。 
269 PTCA における酸化ストレス

東京大学先端科学技術研究センター 山本順宽, 山下聡 鳴門病院 田村克也, 松本直也, 岡崎誠司, 橋詰俊二

【目的】酸化ストレスに最も敏感な抗酸化剈としてアスコルビン酸 と遇元型コエンザイム Q が位置づけられている. そこでこれらの 酸化ストレスマーカーが direct PTCA 治療によりどの梯に変化す るかを追跡した．鳴門病院に入院した急性心筋梗塞患者 9 例から， 術前, 術直後，4，8，12，16，20 時間， 1，2，3，4，7 日後の 血墏を採取した．血獎中のアスコルビン酸，トコフェロール，コエ ンザイム Q の酸化型と逼元型の割合，コレステロール濃度などは 我々の開発した方法で分析した (Free Radical Biol. Med. (1987) 3: 359-361, Anal. Biochem. (1997) 25 0:66-73)

【結果と考察】患者の血墏アスコルビン酸浱度は健常人に比べ明ら かに低いか, PTCA 後もさらに減少し，2-3 日後に最低值をとり， その後は低値のままであった.コエンザイム $Q$ の酸化型の割合 （\%CoQ）は PTCA 直前と直後でそれぞれ $9.9 \pm 2.8$ and $11.4 \pm$ 2.0 であり, 健常人の平均値 $4.4 \%$ に比べ明らかに高い. \%CoQ は その後上昇し， 1-2 日後に 20-45\%に達した後，隇少し 7 日後には 10\%程度に戻った． 総コレステロール量に対するトコフェロール 量は，一部で PTCA 後に減少が認められたが，ほぼ一定であった. 以上の結果は PTCA における酸化ストレスを知る上でアスコルビ ン酸とコエンザイム $Q$ の酸化通元状態の測定が有用であること， PTCA 後少なくとも 2 日间は患者は強い酸化ストレス下にあるこ とが明らかになった。

270 バルーン傷害血管における遺伝子発現

: Subtractive Hybridization 法による検討

鹿児島大学第一内科 宮田昌明、枇榔貞利、江藤英行、折原弘治、 木原貴士、小畑八郎、海江田 寛、鄭 忠和

【背景】PTCA 後の再狭窄のメカニズムを遺伝子レベルで解明する ことは、病態の解明や遗伝子治療を開発するうえで重要である。

【目的】PTCA 後再狭窄モテルであるバルーン倠害血管の遗伝子発 現を Subtractive Hybridization(SH)法を用いて検討すること。【方 法】家鬼大動脈をバルーンカテーテルで擦過し 24 時間後に中膜の みを分離した傷害 $(+)$ 群とバルーン傷害を加えていない賃害(-)群 から mRNA を抽出し、SH 法を行った。【結果】三次スクリーニ ング後、傷害 $(+)$ 群のみに強く発現している $6 \supset$ のロニーを得、 シークエンスをおこない、(1)apolipoproteinJ(apoJ)/clusterin、 (2)importin 、 (3)tumor associated protein 、(4) $\alpha$-globin 、 (5) $\alpha$-actin、 (6)mitochondrial DNA の 6 つの既知遭伝子と同定さ れた。ノーザンブロットの結果、 apoJが最も強くバルーン刺徼に より誘導されていたので、今回 $\mathrm{apoJ}$ に注目して以下の検討をおこ なった。我々がクローニングした家鬼 apoJ は、1344bp の open reading frame を有し、既報のヒトとマウスとラットとはアミノ酸 レベルで約 $80 \%$ の相同性を示した。家兔大動脈バルーン賃害血管 のノーザンブロットでは、apoJ の mRNA は傷害後 6 時間までは発 現しておらず、12 時間から発現しはじめ、24時間と 2 日にピーク を示し、以後渐減し、14日ではわずかに発現していた。免疫組織 化学染色では、傷害後 5 日には中膜に、新生内膜が形成される 14 日には中膜と新生内膜に apoJ 蛋白の発現を認めた。また、in situ hybridization 法にて apoJ の mRNA が、中膜と新生内膜の平滑筋 細胞に発現していることを確認した。【総括】apoJ はバルーン䂓 害血管の中膜と新生内膜に mRNA と蛋白ともに発現しており、バ ルーン傷害後の新生内膜肥厚に関与している可能性が示唆された。
271

動脈性疾患に対するステント治療

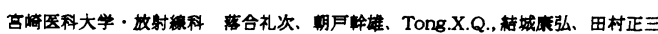
宫崎医科大学・第 2 外科 中村都英、鬼沶繁男

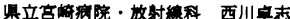

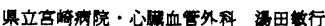

【目的】今回我々は、大動脈㿔や大動脈解離に対するステント グラフトと末梢動脈領域の狭窄・閉塞性病変に対するステント治 療の有効性を検封し、報告する。

【方法】ステントグラフトは最近 1 年間で 8 例に、大腿あるい は外腸骨動脈を外科的に蕗出（1例は開胸下に大動脈を露出）し 挿入した。その内訳は、動脈解離 3 例、真性動脈瘤 3 例、感染性 動脈㾇 1 例、ベーチェット病 1 例である。末梢動脈のステントは 最近 3 年間で 14 例に、経皮的に大腿動脈を呀刺し挿入した。そ の内訳は腸骨動脈11例(動脈硬化性10例、外稘性1例)、䁌動脈2 例(動脈硬化性之線維筋異形成疑い 1 例づつ)、鎖骨下動脈(外偒 性疑い)1例である。

【結果】真性動脈嘴の1例は術中破裂を起こしたが、再挿入に より回復した。破裂は、適切な位置に留置しなかったためであり、 3D-CT等を駆使した術前のシュミレーションが大切と思われた。 腸骨動脈の 1 例は術後 3 時間後に破裂を起こし、開腹手術の上、 グラフトにより血管を再建した。破裂部は屈曲が強く壁の石灰化 が著名であり、同部へパルマッツステントを用いて過度に执張し たためと思われた。2例を除いた、残り20例は手技的に成功した。

【結論】初期成功率は高いものの、動脈破裂を 2 例経験した。 長期成續に関しては、㭘討中である。

\section{2 血管形成術後の再狭窄抑制に対し放射線（Iridium-192） 高線量血管内照射の有効性の検討}

慈患医科大学附属柏病院 総合内科 鈴木昭彦

[目的] 冠動脈形成術において再狭窄は大きな問題である。今 回、放射線（Ir-192）高線量の血管内照射が内膜新生を抑制す る効果を利用して内膜損伤動脈の再㹧寉抑制を家兔を用いて 検埠した。

[方法] 家鬼（日本白色種；雄，3.0-3.5 Kg）20 羽を使用。静 脈麻醉下に左頚動脈を露出,穿刺下にバルーンカテーテル $(3.0 \mathrm{~mm} \times 20 \mathrm{~mm})$ を腸骨動脈へ择入。6 気圧 1 分間の拡張と 1 分間のインターバルを 3 回繰り返し内膜損偒血管モデルを両腸 骨動脈に作成。引き続き Ir-192 高線源を用いて一側の内膜損偒 部位を含み長さ $30 \mathrm{~mm}$ 、深さ $2 \mathrm{~mm}$ を基準とし $12 \mathrm{~Gy}$ の内照射を 施行。照射後 4 週間経過した時点で両腸骨動脈を定圧潅流固定 し摘出，H-E 染色及び van-Gieson 染色施行し、照射血管之対照 血管の再狭窄抑制効果及び高線量の血管内照射の影響を検討 した。

[結果] 4 週間後に定圧潅流を行い得たのは 7 例であった。他 の 13 例は術中あるいは術後 1 日以内に出血多量等の理由で死 亡した。照射群では固定骤本の面積計算上、全例内膜增殖が対 照群に比較して有意に抑制された。血管構造においても保たれ ていた。

[総括］1）動脈内膜のバルーン損偒に対し同部位への同時内 腔照射は内膜增殖抑制効果が期待されることが示唆された。 2) 人間の平均冠動脈径とほほ等しい家鬼の腸骨動脈にて再狭 宗が血管内照射により抑制されたことより人間の冠動脈形成 術後の再狭窄も抑制される可能性が推測された。 
273 エストロゲンの抗動脈硬化作用における浱度の影響

一内膜擦過十高コレステロール負荷による進行動脈硬化モデ ル(家鬼)を用いて一

名古屋大学医学部老年科学 林 登志雄、加納初世、武藤恵美子、 江崎貞治、井口昭久

目的）エストロゲンの抗動脈硬化作用において、血管壁への直接作用 が寄与する部分が多いことが知られてきたか、詳細は不明である。今 回は、生理学的婊度のエストロゲン (17 ß estradiol,E2)が抗動脈硬化作 用を示すか、その機序についても併せて検討する。

方法）４8 羽の卵巣摘出雌性ニュージーランド白色家兔の腹部大動脈 をバルーン擦過し、以下の 5 群に分け 10 週飼育した。Gpl:普通食

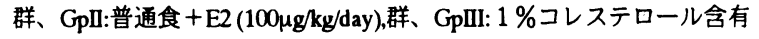
食群、GplV:高コレステロール食+E2 (100 $\mu \mathrm{g} / \mathrm{kg} / \mathrm{day})$ 群、GpV: 高コレ ステロール食+E2 $(20 \mu \mathrm{g} / \mathrm{kg} / \mathrm{day})$ 群。飼育後、血清脂質、性ホルモン浱 度、動脈硬化形成度（表面積占有度、内腔占有度）、NO関連血管反 応、血中代謝物等を測定した。

結果）E2投与により、血中脂質灌度には有意な変化を認めなかった。 血墏E2湍度はGpII、GpIV、GpV各々, $282 \pm 46,263 \pm 42,88 \pm 19(\mathrm{pg} / \mathrm{ml}) に 上$ 昇していた。動脈硬化形成度は胸部、腹部ともE2投与により減少して いた。NO合成酳素阻害菜LNMA投与による血管収縮反応、cGMP血管 壁中脳度、血獎 $\mathrm{NO}_{2} / \mathrm{NO}_{3}$ 搌度により検討した $\mathrm{NO}$ 基礎分泌反応は、E2投 与により上昇した。アセチルコリンによるNO刺激分泌も GpIIIで、 ほとんど認められない程度に減弱したが、E2投与により改善傾向にあ った。

結論）E2投与は、投与レベルが生理学的濃度であっても、基䃈NO分 泌反応が六進し、コレステロール食負荷または内膜擦過後の動脈硬化 性変化のみならず、双方の刺激による進行動脈硬化症においても、抗 動脈硬化作用を示す。

274 経皮吸收型工不ラジオール製剤の血管拡張反応に及ぼす影響 一虚血性心疾患を有する閉経後女性での検討-

兵庫医科大学第一内科

大平昭子、桝谷充男、奥村隆啓、志水栄伸、藤原正義

朝限 進、岩崎忠昭

【目的】虚血性心疾患患者に抢ける工外听”補充療法の内皮依 存性血管搪張反応(VD)への慢性期改善効果の報告はあるが、 早期効果は不明である。今回、閉経後女性に経皮吸收型工訃ラシ” オール製剤(E2)を用い、48時間後のVDを検討した。【対象・方 法】当科に入院した閉経後女性14例を、冠動脈造影上有意狭 窄を有する7例(IHD群)、有さない7例(N群)に分け以下の比較 検討を行った。右橈骨動脈の血管径を高解像度超音波にて測 定。次に上腕動脈を5分間駆血し、駆血解除後の血管最大径を 測定し、駆血前後で拡張率を算出しC\%とした。E2(4mg)貼布 48時間後㧍よびプラ划 薬貼布48時間後で同様に血管搪張率を 求め、各々E\%、P\%とした。また各時点でのニ辝临邚錠舌 下による血管搪張率、さらに安静時前腕血流量をプレチ饪グラフ 一にて測定した。【結果】二ト吼”临錠舌下による血管搪張率、 および安静時前腕血流量にはいずれも有意差を認めなかった。 両群間で脂質、糖代謝、肥満、血管径化有意差を認めなかっ

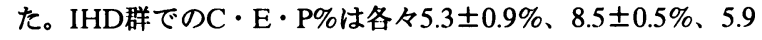
$\pm 0.8 \%$ で、 $\mathrm{E} 2$ 投与後でのみ改善を認めた( $\mathrm{C}$ vs $\mathrm{E}, \mathrm{p}<0.05)$ 。

一方N群では $10.7 \pm 1.6 \% 、 13.3 \pm 1.9 \% 、 10.3 \pm 1.5 \%$ と有意差 を認めなかった。【総括】E2貼付によるVD改善効果はIHD 群でのみ認められた。これはN群のC\%がIHD群より高い事よ り、N群では投与前より血管内皮機能が良好で、E2貼付にて む搪張率に差はなかったためと思われた。以上より動脈硬化 による血管内皮機能障害が存在すると考えられる場合、E2製 版は早期より内皮依存性血管拡張反応を改善すると期待され た。

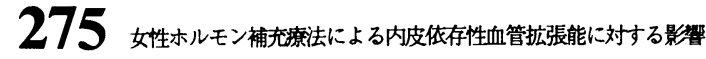
-2 年にわたる臨床的検討一

東京大学大学院医学系研究科加龄医学講座

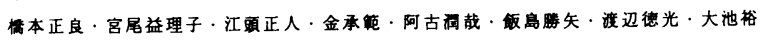

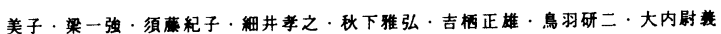

【目的】閉経後女性に対する女性ホルモン補充療法 (HRT) が、動 脈硬化性疾患の発症を抑制することが疫学的に示されている。しか しその機序の詳細は不明である。本研究ては、中長期にわたるHRT が血管内皮機能にどのような影幚を及はすかを経時的に検討した。

【方法】明らかな動脈硬化性疾患を有さない閒経後女性 8名(54.8 \pm 1.4 藏)を対象とした。内皮依存性血管拡張能として超音波を用い 上腕動脈における血流依存性血管拡張反応(\%FMD)を、内皮非依存 性血管拡張反応としてニトログリセリン噴蓩後の血管径の増加率 (\%NTG) 計测した。計測時期はHRT開始前、開始3、6、12、18、 24个月後とし、血圧、血清脂澌、空腹時血糖を同時に測定した。 【結果】\%FMDはHRT開始後增加傾向を示し、開始6个月後以降て \%FMDは有意に增加し、その奻果は24个月まで認められた(開始前 $5.1 \%$ 、開始6个月後7.5\% $P<0.05$ 、開始 12 个月後 $8.7 \% P<0.01$ 、開始 18 个月後 $7.9 \% P<0.01$ 、開始 24 个月後 $8.4 \% P<0.01)$ \% \% NTGには の傾向は認められなかった。血清NOxレベルは各時期で差を認めな かった。また総コレステロール值、HDLコレステロール值、中性脂 肪值、血榶值、血圧には各時期で差を認めなかったが、血清Apo $\mathrm{E}$ はHRT開始6个月後以降で有意に低下した。【桔論】 HRTは内皮依存 性血管拡張反能を改善し、治療期間中にその効果は持続した。閉経 後女性に对するHRTによる動脈硬化性疾患の発症抑制には、女性木 ルモンの内皮機能改善が関与している可能性が示唆された。

\section{6 隔日投与法によるホルモン補充療法(HRT)と HMG-CoA} 還元䤃素阻害剂 (Simvastatin) 併用療法の有効性の検討

徳島大学産科婦人科、特殊栄盖1

岡田典子，安井敏之，苛原稳，中屋豊1)、青野敏博

【目的】閉経後の高脂血症患者に対して、隔日投与法によるHRTと Simvastatin(S)の併用療法の有効性を検討した.

【方法】当科更年期外来に通院する高脂血症を有する閉経後女性 54例を, 結合型エストロゲンと酢酸メドロキシプロゲステロンの 連日投与によるHRT治療群( I 群)、隔日投与によるHRT治療群 (II 群)、S単独群(四群))、隔日投与によるHRTとSの併用群(N群) に分け，治療前，および治療後6ヶ月，1年におけるTC，TG， HDL-C, LDL-C, アポ蛋白について比較检討した.

【結果】TCは I 群で 1 年後 $12.3 \%$ 减少したのに対し、I 群では 10.2 \%の減少にとどまったが, N群で14.5\%の減少が認められた. HDL-CについてはI 群で 1 年後に $14.9 \%$ 增加したが、II群は 3.2 \%しか增加しなかった。しかしSの併用(N群)によって10.4\%增加 した. LDL-Cは1年後 I 群では $22.3 \%$ 減少したが，II群では 13.9 \%の減少にとどまり，Sの併用(䟻)によって24.0\%の減少が認め られた. 同様に, アポ蛋白についても隔日投与群は連日投与群に 比べて効果は低かったが，Sの併用により効果が增強された。

【結論】高脂血症に対するHRTの治療効果ては, 隔日投与は連日投 与に比べて効果は低いが、Simvastatinを併用することにより連 日投与に匹敵する効果が認められることが明らかとなった。 